\title{
Climate variability and human impact in South America during the last 2000 years: synthesis and perspectives from pollen records
}

\author{
S. G. A. Flantua ${ }^{1}$, H. Hooghiemstra ${ }^{1}$, M. Vuille ${ }^{2}$, H. Behling ${ }^{3}$, J. F. Carson ${ }^{4}$, W. D. Gosling ${ }^{1,5}$, I. Hoyos ${ }^{6}$, M. P. Ledru ${ }^{7}$,

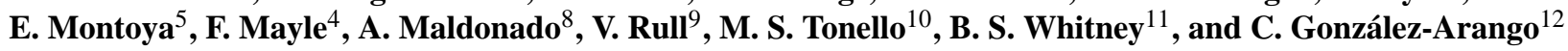 \\ ${ }^{1}$ Institute for Biodiversity and Ecosystem Dynamics (IBED), University of Amsterdam, Science Park 904, 1098 XH \\ Amsterdam, the Netherlands \\ ${ }^{2}$ Department of Atmospheric and Environmental Sciences, University at Albany, State University of New York, \\ Albany, NY, USA \\ ${ }^{3}$ Georg August University of Göttingen, Albrecht von Haller Institute for Plant Sciences, Department of Palynology and \\ Climate Dynamics, Untere Karspüle 2, 37073 Göttingen, Germany \\ ${ }^{4}$ Department of Geography and Environmental Science, University of Reading, Reading, RG6 6AB, UK \\ ${ }^{5}$ Department of Environment, Earth \& Ecosystems, The Open University, Walton Hall, Milton Keynes, MK7 6AA, UK \\ ${ }^{6}$ Faculty of Engineering, GAIA, Institute of Physics Group Fundamentos y Enseñanza de la Física y los Sistemas Dinámicos, \\ Universidad de Antioquia, Medellin, Colombia \\ ${ }^{7}$ Institut des Sciences de l'Evolution de Montpellier (ISEM) UM2 CNRS IRD EPHE, Place Eugène Bataillon, Cc 061, \\ 34095 Montpellier CEDEX, France \\ ${ }^{8}$ Centro de Estudios Avanzados en Zonas Áridas (CEAZA), Universidad de La Serena. Av Raúl Bitrán 1305, La Serena, Chile \\ ${ }^{9}$ Institute of Earth Sciences "Jaume Almera" (ICTJA-CSIC), C. Lluís Solé Sabarís s/n, 08028 Barcelona, Spain \\ ${ }^{10}$ Instituto de Investigaciones Marinas y Costeras CONICET, Universidad Nacional de Mar del Plata, \\ Mar del Plata, Argentina \\ ${ }^{11}$ Department of Geography, Ellison Place, Northumbria University, Newcastle upon Tyne, NE1 8ST, UK \\ ${ }^{12}$ Departamento de Ciencias Biológicas, Universidad los Andes, A.A. 4976 Bogotá, Colombia
}

Correspondence to: S. G. A. Flantua (s.g.a.flantua@uva.nl) and H. Hooghiemstra (h.hooghiemstra@uva.nl)

Received: 31 May 2015 - Published in Clim. Past Discuss.: 29 July 2015

Revised: 17 December 2015 - Accepted: 4 January 2016 - Published: 29 February 2016

\begin{abstract}
An improved understanding of present-day climate variability and change relies on high-quality data sets from the past 2 millennia. Global efforts to model regional climate modes are in the process of being validated against, and integrated with, records of past vegetation change. For South America, however, the full potential of vegetation records for evaluating and improving climate models has hitherto not been sufficiently acknowledged due to an absence of information on the spatial and temporal coverage of study sites. This paper therefore serves as a guide to highquality pollen records that capture environmental variability during the last 2 millennia. We identify 60 vegetation (pollen) records from across South America which satisfy geochrono-
\end{abstract}

logical requirements set out for climate modelling, and we discuss their sensitivity to the spatial signature of climate modes throughout the continent. Diverse patterns of vegetation response to climate change are observed, with more similar patterns of change in the lowlands and varying intensity and direction of responses in the highlands. Pollen records display local-scale responses to climate modes; thus, it is necessary to understand how vegetation-climate interactions might diverge under variable settings. We provide a qualitative translation from pollen metrics to climate variables. Additionally, pollen is an excellent indicator of human impact through time. We discuss evidence for human land use in pollen records and provide an overview considered useful 
for archaeological hypothesis testing and important in distinguishing natural from anthropogenically driven vegetation change. We stress the need for the palynological community to be more familiar with climate variability patterns to correctly attribute the potential causes of observed vegetation dynamics. This manuscript forms part of the wider LOngTerm multi-proxy climate REconstructions and Dynamics in South America - 2k initiative that provides the ideal framework for the integration of the various palaeoclimatic subdisciplines and palaeo-science, thereby jump-starting and fostering multidisciplinary research into environmental change on centennial and millennial timescales.

\section{Introduction}

Accurately simulating the complexity of Earth's climate system is still a major challenge for even the most advanced Earth system models. One major obstacle for evaluating model performance in historical runs is the lack of long and reliable climate records from some regions of the Earth. Given the scarcity of instrumental records in many regions, alternative, proxy-based climate reconstructions therefore provide an excellent data set against which to test models and their ability to accurately simulate longer-term features of climate change. Proxy data sets from sedimentary records (in particular pollen, charcoal, and tephra from lake sediments and peat bogs) have been particularly underutilized in this regard.

Increasingly studies have demonstrated the integration of multiple proxies ( $\mathrm{Li}$ et al., 2010) in climate reconstructions, with a special focus on the last 2 millennia. This period could be considered a baseline to current conditions, as climate has been very similar to the present. This integration is still in its infancy in South America (SA), especially in the tropics. Since 2009, regional climate reconstructions from SA have gained momentum from compilations of multiple data sets and from fine-tuning of model reconstruction methods (Villalba et al., 2009). However, an improved understanding of the spatial distribution of proxy data sets has been identified as necessary to make further progress (Villalba et al., 2009; Flantua et al., 2015). Tree ring studies constitute a widely distributed and frequently used high-resolution climate archive that has fortunately recently expanded its spatial coverage (Boninsegna et al., 2009; Villalba et al., 2009). However, the tree ring records are limited compared to the spatial and temporal coverage provided by records obtained from sedimentary archives (e.g. pollen records). The newly updated inventory of palynological research in SA documents the extensive spatial and temporal coverage of pollen-based research available throughout the continent (Flantua et al., 2015). However, to integrate records from different sedimentary archives across SA, a standard chronological framework is required. To this end an alternative recalibrated age model and evaluation of chronologies have been undertaken to facilitate the integration of multi-proxy records in SA (Flantua et al., 2016). However, multi-proxy climate reconstructions from the last 2 kyr have hitherto been focused mainly on southern SA (PAGES-2k Consortium, 2013), omitting input from the northern two thirds of the continent. Furthermore, palynological research has been underrepresented in most reconstructions of climate variability (Villalba et al., 2009; Neukom et al., 2010; Neukom and Gergis, 2012). The lack of an adequate overview of available pollen records from the continent has been an impediment to the advancement of its use and inclusion in climate studies.

As a result, we identified the need to review and discuss pollen records in SA that can fulfil requirements for inclusion in $2 \mathrm{ka}$ palaeoclimate reconstructions, within the framework of LOng-Term multi-proxy climate REconstructions and Dynamics in South America (LOTRED-SA, this Special Issue) and the PAGES-2k Network (http://www.pages-igbp.org/ini/ $\mathrm{wg} / 2 \mathrm{k}$-network/intro). This paper is structured following an assessment for individual regions in SA within the context of current climate modes. These modes are characterized by their precipitation and temperature fingerprint over SA and used as a baseline framework to identify past climatic changes from pollen records. Certain zones are more prone to particular climate signals; therefore, comparison between the spatial expression of climate modes and highly correlated records from different regions strengthens the interpretation of palaeoecological findings. To use pollen as a palaeoclimate proxy, the degree of human impact on the vegetation needs to be considered as being minimal or absent over the last $2 \mathrm{kyr}$. Therefore, drivers of vegetation change, both natural and anthropogenic, are discussed within the different regions to describe the general settings required for palaeoecological research in the last millennia. Records that identify significant human impact are identified and excluded from the proposed data set for PAGES-2k when the climate signal is lost but are considered useful within the regional purposes of LOTRED-SA (this Special Issue). We provide a qualitative translation from pollen metrics to climate variables based on expert knowledge. We finish by discussing the potential of including pollen-inferred climate information in 2 ka climate model validation and emphasize the importance of multi-proxy working groups such as LOTRED-SA.

\section{Climate settings}

\subsection{Continental overview climate zones and modes}

We begin with an overview of the main climate "zones" of SA to provide the climatological context for a discussion of pollen records covering the past 2000 calibrated years before present ( 2 cal yr BP). Climate zones are regions of coherent seasonality and mean climate (intra-annual climate regime), while climate "modes" are based on ocean-atmosphere interactions, with often oscillatory behaviour affecting the interannual to multidecadal climate variability in a region. The 
spatial influence of climate modes is assessed by documenting their role in driving interannual precipitation and temperature variability.

Continental SA extends from the tropics $\left(12^{\circ} \mathrm{N}\right)$ to midlatitudes $\left(55^{\circ} \mathrm{S}\right)$. Three major noticeable climate zones can be distinguished: tropical, subtropical, and extratropical SA. Atmospheric circulation and climate in all three zones is highly modulated and constrained by the orography of the Andes, the shape of the continent, and interactions with the underlying land surface, vegetation, and soil moisture; furthermore, ocean currents, such as the cold Humboldt Current affecting coastal climate along the South American west coast, also affect climate (Wang and $\mathrm{Fu}, 2002$; $\mathrm{Li}$ and $\mathrm{Fu}, 2006$ ).

The climate of tropical SA is dominated by the seasonal migration of the Intertropical Convergence Zone (ITCZ) over the Atlantic and Pacific, and the seasonal development of convective activity associated with the South American summer monsoon (SASM) over the interior of the continent (Fig. 1). The seasonal migration of the ITCZ primarily affects coastal areas and northernmost SA as it is characterized by a fairly well-constrained narrow band of low-level wind convergence over the equatorial oceans. The SASM is a seasonal phenomenon that develops between September and April and primarily affects the SA tropics and subtropics south of the Equator (Garreaud et al., 2009). During the austral spring (September to November, SON) moisture influx from the ITCZ contributes to the development of this monsoon system (Zhou and Lau, 2001; Vuille et al., 2012). This monsoonal system reaches its mature phase (maximum development) during December to February (DJF) and is characterized by heavy rainfall advancing southward from tropical to subtropical latitudes. To the east of the tropical Andes a strong low-level wind, the Andean low-level jet (ALLJ), transports moisture in a southeasterly direction from the tropics to the subtropical plains (Cheng et al., 2013), feeding the South Atlantic convergence zone (SACZ), extending from the southeastern (SE) Amazon basin toward the southeast out over the South (S) Atlantic. The extratropical region is characterized by a quasi-permanent westerly circulation embedded in between the subtropical anticyclones located over the subtropical Pacific and Atlantic to the north and the circumpolar trough of low pressure to the south. Frequent northward propagation of extratropical cold air incursions east of the Andes provide for continued atmospheric interaction and heat exchange between mid- and low latitudes over the subtropical continent. The latitudinal extension of the westerlies over land displays limited variations across the year and covers southern and central (C) Argentina and Chile. Additional information is presented in the Supplement.

Both precipitation and temperature exhibit significant variability on interannual to interdecadal timescales in all three climate zones of SA (e.g. Garreaud et al., 2009). This variability is mainly caused by ocean-atmosphere interactions (Vuille and Garreaud, 2012) that lead to a reorganization of the large-scale circulation over SA and the neighbouring

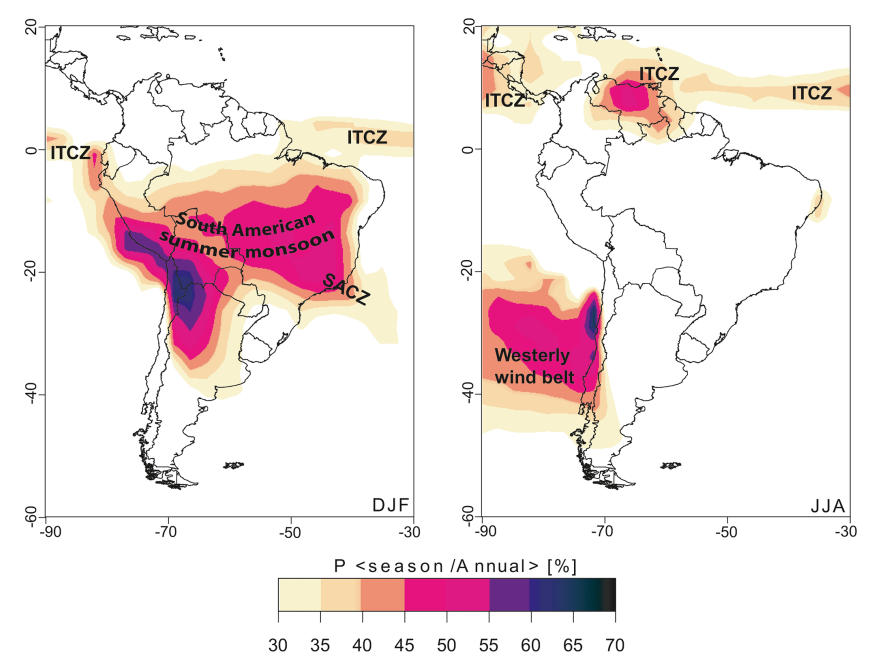

Figure 1. Map showing the relative precipitation amount over South America during the key seasons DJF (austral summer and mature monsoon phase) and JJA (dry season over much of tropical South America), highlighting the Intertropical Convergence Zone (ITCZ), South American summer monsoon, South Atlantic convergence zone (SACZ), and extratropical westerlies. Figure based on CPC Merged Analysis Precipitation (CMAP) data. Adapted from Vuille et al. (2012).

oceans. To quantify the influence and relative importance of these ocean-atmosphere coupled modes on the interannual precipitation and temperature variability over SA, spatial correlation and regression coefficients are calculated.

Gridded precipitation and temperature data were derived from the UDelaware data set V2.01 (Legates and Willmott, $1990)$ at $0.5^{\circ}$ resolution. We limit our assessment to the six most relevant climate modes (Table 1). Other modes analysed were either largely redundant or showed a much weaker influence over the SA continent. The resulting correlation maps indicate the correlation coefficient on interannual timescales between the mode in question and the local temperature and precipitation at each grid cell. Conversely, the regression maps indicate the local anomaly (in physical units of millimetres or degrees Celsius) at each location that corresponds to a unit (1 standard deviation) anomaly in the climate mode. The Southern Annular Mode (SAM) and all three Atlantic modes (Atlantic Multidecadal Oscillation - AMO; tropical North and South Atlantic sea surface temperature TSA and TNA; Table 1) were detrended prior to analysis to ensure that correlation and regression coefficients account for co-variability on interannual timescales only and do not result from spurious common trends. More information on the methodology can be found in the Supplement.

In all correlation maps (Figs. 2 and 4) we show correlations in excess of \pm 0.2 only, which approximately corresponds to the $95 \%$ significance level. For the regression maps (Figs. 3 and 5), we used thresholds of $\pm 0.12^{\circ} \mathrm{C}$ and $\pm 50 \mathrm{~mm}$, respectively. The correlation maps can help inform 
Table 1. Climate modes used relevant for South America. SST: sea surface temperature; HadISST: Hadley Centre Global Sea Ice and Sea Surface Temperature; EOF: empirical orthogonal function; NOAA OI: National Oceanic and Atmospheric Administration Optimum Interpolation.

\begin{tabular}{|c|c|c|c|c|}
\hline Abbreviation & Mode & Methods & Description & Reference \\
\hline Niño 3.4 & Niño3.4 index & $\begin{array}{l}\mathrm{SST} \text { averaged over } 5^{\circ} \mathrm{N}-5^{\circ} \mathrm{S}, 170- \\
120^{\circ} \mathrm{W} \text { calculated from HadISST data }\end{array}$ & $\begin{array}{l}\text { Describes interannual }(2-7 \mathrm{yr}) \\
\text { variability of tropical } \\
\text { Pacific SST }\end{array}$ & Rayner et al. (2003) \\
\hline AMO & $\begin{array}{l}\text { Atlantic } \\
\text { Multidecadal } \\
\text { Oscillation }\end{array}$ & $\begin{array}{l}\text { Defined as the area-averaged SST in the } \\
\text { Atlantic north of the Equator, calculated } \\
\text { from Kaplan SST V2 }\end{array}$ & $\begin{array}{l}\text { Describes coherent variations } \\
\text { in North Atlantic SST on mul- } \\
\text { tidecadal }(50-70 \mathrm{yr}) \text { timescales }\end{array}$ & Enfield et al. (2001) \\
\hline IPO & $\begin{array}{l}\text { Interdecadal } \\
\text { Pacific } \\
\text { Oscillation }\end{array}$ & $\begin{array}{l}\text { Multidecadal Pacific-wide mode of } \\
\text { SST variability, calculated as the sec- } \\
\text { ond EOF of low-frequency filtered } \\
\text { HadISST data }\end{array}$ & $\begin{array}{l}\text { Describes joint variations in } \\
\text { Pacific SST in both } \\
\text { hemispheres on multidecadal } \\
(20-30 \text { yr) timescales }\end{array}$ & Folland et al. (2002) \\
\hline SAM & $\begin{array}{l}\text { Southern } \\
\text { Annular Mode } \\
\text { or Antarctic } \\
\text { Oscillation }\end{array}$ & $\begin{array}{l}\text { Calculated as leading principal } \\
\text { component (PC) of } 850 \mathrm{hPa} \text { geopoten- } \\
\text { tial height anomalies south of } 20^{\circ} \mathrm{S}\end{array}$ & $\begin{array}{l}\text { Determines strength and loca- } \\
\text { tion of circumpolar vortex } \\
\text { (location of the extratropical } \\
\text { westerly storm tracks) }\end{array}$ & $\begin{array}{l}\text { Thompson and } \\
\text { Wallace (2000) }\end{array}$ \\
\hline TNA & $\begin{array}{l}\text { Tropical North } \\
\text { Atlantic SST }\end{array}$ & $\begin{array}{l}\text { Defined as SST averaged over } 5.5- \\
23.5^{\circ} \mathrm{N}, 15-57.5^{\circ} \mathrm{W} \text { and calculated } \\
\text { from HadISST and NOAA OI } 1 \times 1 \\
\text { data sets }\end{array}$ & $\begin{array}{l}\text { Describes interannual variabil- } \\
\text { ity of SST variations in the } \\
\text { tropical North Atlantic }\end{array}$ & Enfield et al. (1999) \\
\hline TSA & $\begin{array}{l}\text { Tropical South } \\
\text { Atlantic SST }\end{array}$ & $\begin{array}{l}\text { Defined as SST averaged over } 0-20^{\circ} \mathrm{S} \text {, } \\
10^{\circ} \mathrm{E}-30^{\circ} \mathrm{W} \text { (TSA), calculated from } \\
\text { HadISST and NOAA OI } 1 \times 1 \text { data sets }\end{array}$ & $\begin{array}{l}\text { Describes interannual variabil- } \\
\text { ity of SST variations in the } \\
\text { tropical South Atlantic }\end{array}$ & Enfield et al. (1999) \\
\hline
\end{tabular}

us whether a certain temperature or precipitation anomaly in the regression map is statistically significant. In our discussion we focus primarily on the impact of the positive phase from each of these modes, as these are the fingerprints presented in Figs. 2-5. Since this is a linear analysis, the negative phase of these modes would lead to the same changes in temperature and precipitation but with the sign reversed. In general these outcomes are consistent with earlier analyses reported by Garreaud et al. (2009). However, some differences are apparent and most likely related to different time periods analysed, our choice of using the hydrologic year as opposed to the calendar year, and different definitions of the indices used (see the Supplement for more details). For example, Garreaud et al. (2009) used the Multivariate El NiñoSouthern Oscillation (ENSO) index, while here we focus on the Niño3.4 index to describe ENSO variability. Similarly, Garreaud et al. (2009) used the Pacific Decadal Oscillation index to describe Pacific interdecadal variability, while here we use the Interdecadal Pacific Oscillation (IPO).

\subsection{Temperature}

The largest and most significant influence on interannual temperature variability in SA is exerted by ENSO, with above average temperatures during El Niño and reduced temperature during La Niña (Figs. 2 and 3). A 1 standard de- viation departure in the Niño3.4 index is associated with a change in temperature of up to $0.8^{\circ} \mathrm{C}$ along the Pacific coast of SA. In the Andes of Colombia, the correlation between temperature and the Niño3.4 index is $>0.8$, indicating that more than two thirds of the temperature variability on interannual scales can be explained by ENSO. The largest increase in temperature is observed during austral summer (DJF, not shown), linked to the peak phase of ENSO, which tends to occur at the end of the calendar year.

Compared to ENSO, the IPO has a similar, albeit slightly weaker, fingerprint over SA, which is not surprising given that the Pacific decadal and multidecadal variability is often described as "ENSO-like" (e.g. Garreaud and Battisti, 1999). The IPO impact extends further south along the west coast of SA than ENSO, however, with a somewhat stronger influence on temperature in northern $(\mathrm{N})$ to $\mathrm{C}$ Chile. It is noteworthy that the IPO impact over SA is almost identical to the influence of the Pacific Decadal Oscillation as described in Garreaud et al. (2009).

The N Atlantic modes, AMO and TNA are also quite similar, both featuring warming over tropical SA during periods when sea surface temperature (SST) in the N Atlantic domain is above average, most notably so over the southern C Amazon basin (Figs. 2 and 3). In fact the warming associated with a unit variation in the AMO or TNA index is larger over most of the Amazon basin than the warming 

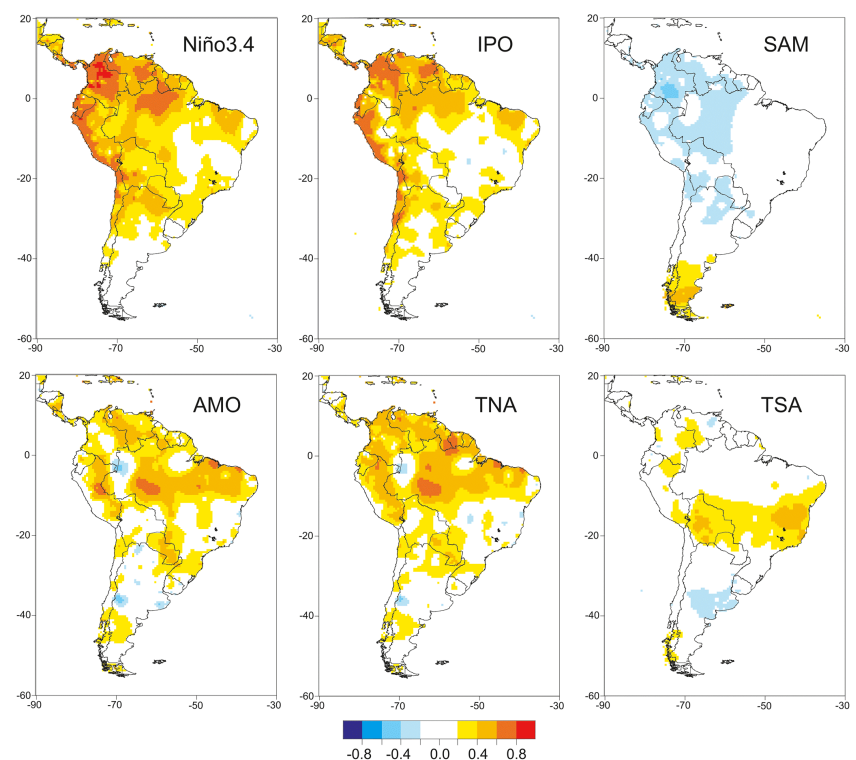

Figure 2. Correlation of annual mean temperature over South America with climate modes Niño3.4, IPO (Interdecadal Pacific Oscillation), SAM (Southern Annular Mode), AMO (Atlantic Multidecadal Oscillation), TNA (tropical North Atlantic SST), and TSA (tropical South Atlantic SST). High positive values of the correlation coefficient indicate both increasing and decreasing values of the mode in question and the local temperature at each grid cell. High negative values indicate that the increasing (decreasing) mode in question causes a significant decrease (increase) in temperature at the grid cell. Gridded temperature fields are from the University of Delaware (1958-2008). Only correlations in excess of \pm 0.2 are shown (roughly the threshold of the $95 \%$ significance level).

associated with ENSO. The region of largest warming is colocated with an area of strong precipitation reduction during the warm phase of the TNA and the AMO (Figs. 4 and 5). This suggests that much of the warming is caused by cloud cover and soil moisture feedbacks associated with reductions in precipitation (reduced cloud cover leading to enhanced solar radiation and reduced soil moisture limiting evaporative cooling).

The S Atlantic counterpart, the TSA, is associated with a temperature dipole over subtropical SA, characterized by warming along a zonal band extending from the S-C Brazilian coast westward to Bolivia, while $\mathrm{C}$ Argentina contemporaneously experiences cooling (Figs. 2 and 3). The warming in the subtropical region coincides with a region of reduced precipitation during the TSA positive phase (Fig. 4), suggesting that the warming is at least in part caused by changes in the hydrological cycle (cloud cover and/or soil moisture feedbacks).

The SAM is positively correlated with temperature over Patagonia (Fig. 2) and also shows a weak negative temperature departure over western tropical SA during its positive phase (Fig. 3). The warming over Patagonia is strongest during austral summer (Garreaud et al., 2009; not shown) and
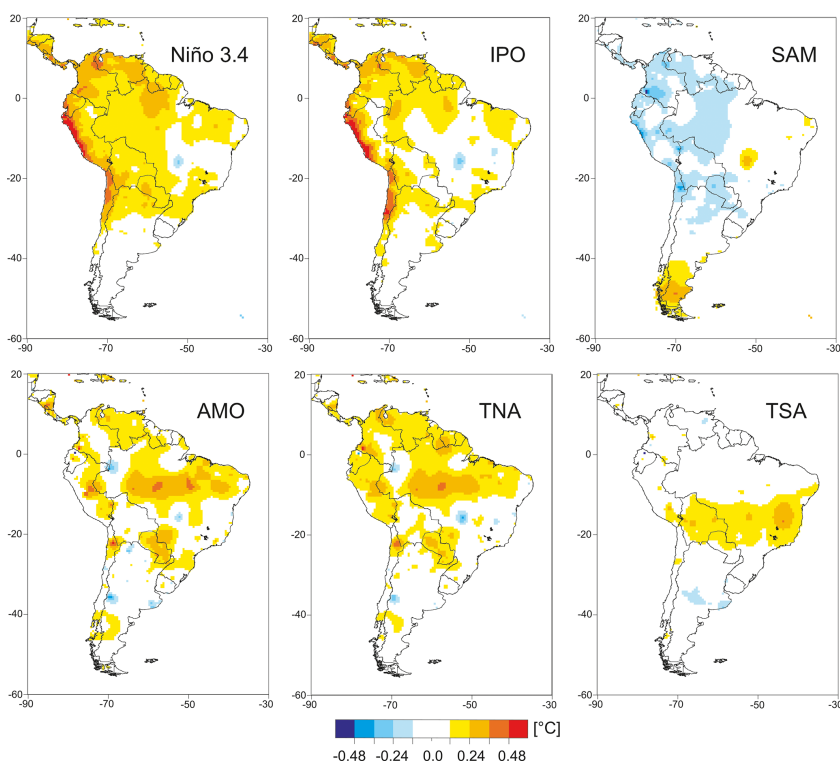

Figure 3. Annual mean temperature regressed upon Niño3.4, IPO (Interdecadal Pacific Oscillation), SAM (Southern Annular Mode), AMO (Atlantic Multidecadal Oscillation), TNA (tropical North Atlantic SST), and TSA (tropical South Atlantic SST). High positive values of the regression coefficient indicate that positive (negative) temperature anomalies occur during the positive (negative) phase of the mode in question. High negative values indicate that the positive (negative) phase of a mode leads to a decrease (increase) in temperature at the grid cell. Gridded temperature fields are from the University of Delaware (1958-2008).

results from enhanced heat advection, combined with higher solar radiation receipts due to cloud-free conditions (Gupta and England, 2006).

\subsection{Precipitation}

Given that ENSO is the source of the strongest interannual variability on Earth, it is not surprising that it also leads to the strongest modern precipitation anomalies over SA (Fig. 5). In general in the tropics, El Niño events lead to significant precipitation reductions over much of tropical SA, with the strongest signal seen in $\mathrm{N}$ Brazil along the Atlantic coast and in the Andes of Colombia. Over northeast (NE) Brazil the precipitation reduction is the result of El Niño events inducing a delayed anomalous warming of the tropical N Atlantic in boreal spring (March-May) (e.g. Curtis and Hastenrath, 1995; Giannini et al., 2001). Hence, the ENSO influence in this region strongly projects onto the TNA pattern (Fig. 4). Over the N Amazon basin the precipitation reduction is the result of a shifted Walker circulation, enhanced subsidence, and reduced convective activity (e.g. Liebmann and Marengo, 2001; Ronchail et al., 2002). In the subtropics, on the other hand, precipitation is enhanced during El Niño events, in particular over southeastern SA (see also Grimm et al., 2000). The only tropical location that sees an increase 


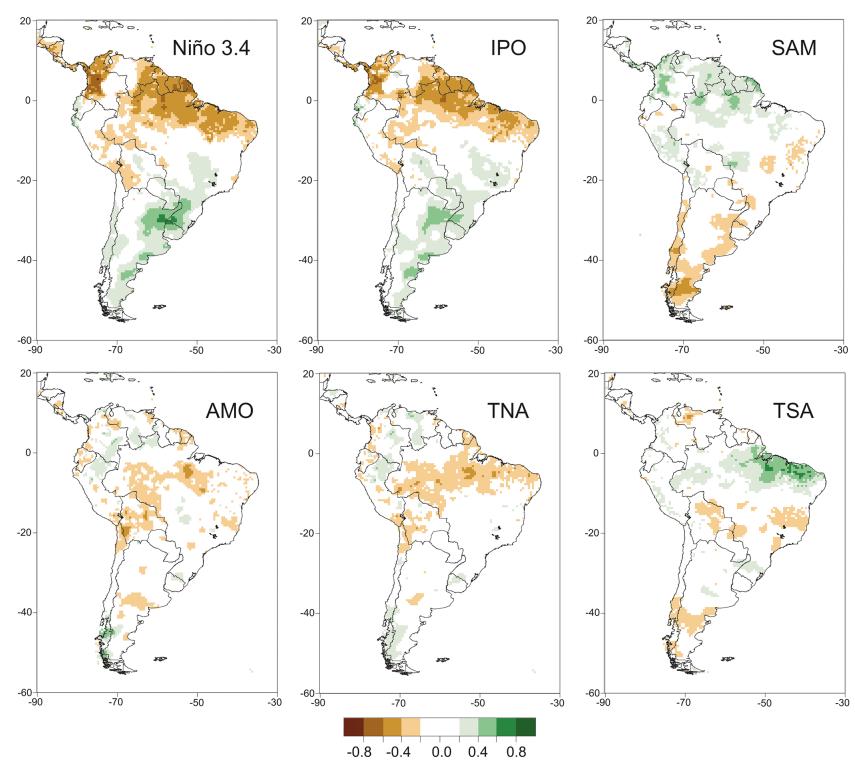

Figure 4. Precipitation correlation with modes Niño3.4, IPO (Interdecadal Pacific Oscillation), SAM (Southern Annular Mode), AMO (Atlantic Multidecadal Oscillation), TNA (tropical North Atlantic SST), and TSA (tropical South Atlantic SST). High positive values of the correlation coefficient indicate both increasing and decreasing values of the mode in question and the local precipitation at each grid cell. High negative values indicate that the increasing (decreasing) mode in question causes a significant decrease (increase) in precipitation at the grid cell.

in precipitation during El Niño is along the Pacific coast of Ecuador and northern Peru, where flooding is a common occurrence during these events (e.g. Takahashi, 2004). During La Niña events these precipitation anomalies are essentially reversed. The correlations are weaker in our annual analysis over some regions where the ENSO influence is highly seasonal, such as the precipitation reduction over the C Andean "Altiplano" (high plain) region in DJF (Vuille et al., 2000) or the enhanced precipitation during El Niño in C Chile in June to August (JJA; Montecinos and Aceituno, 2003).

The largest change in the IPO in the period analysed is related to the Pacific climate shift of 1976-1977, when the tropical Pacific switched from its cold to its warm phase. Since El Niño events also became more frequent and stronger over this period (including the two extreme events of 19821983 and 1997-1998), it is no surprise that the observed changes in precipitation associated with the IPO are similar to the ENSO footprint, albeit somewhat weaker. Indeed the low-frequency modulation by the IPO may strengthen El Niño events during its positive phase and weaken La Niña events, while the opposite is the case during the IPO negative phase, a phenomenon known as "constructive interference" (e.g. Andreoli and Kayano, 2005). Espinoza Villar et al. (2009) documented the influence of Pacific interdecadal variability on precipitation over the Amazon basin
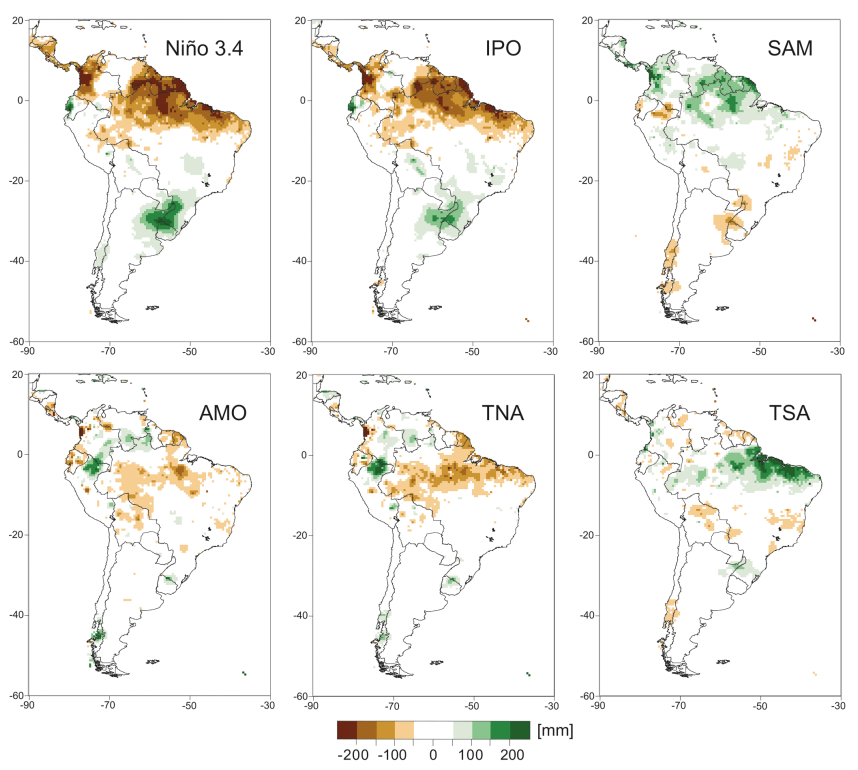

Figure 5. Precipitation regression with modes Niño3.4, IPO (Interdecadal Pacific Oscillation), SAM (Southern Annular Mode), AMO (Atlantic Multidecadal Oscillation), TNA (tropical North Atlantic SST), and TSA (tropical South Atlantic SST). High positive values of the regression coefficient indicate that positive (negative) precipitation anomalies occur during the positive (negative) phase of the mode in question. High negative values indicate that the positive (negative) phase of a mode leads to a decrease (increase) in precipitation at the grid cell.

and showed that its positive phase is related to a decrease in precipitation over the basin since 1975, consistent with our results.

Precipitation is reduced in the southernmost part of SA during the positive phase of the SAM (Fig. 4). This reduction extends north into the subtropics along both the Atlantic and Pacific coast to approximately $30^{\circ} \mathrm{S}$ (Silvestri and Vera, 2003; Gillett et al., 2006). Most of this precipitation reduction is associated with reduced westerly moisture flux and moisture convergence from the Pacific (Garreaud et al., 2013). The correlation (Fig. 4) and regression (Fig. 5) maps also suggest a significant influence of the SAM on precipitation in parts of the tropics. This signal, however, is not well documented and its physical mechanism is unclear. It may to some extent be related to teleconnections and an anticorrelation between ENSO and the SAM (e.g. Carvalho et al., 2005), which is supported by the fact that the Niño3.4 index and the SAM correlation maps are almost mirror images of one another (Fig. 4).

The AMO and the TNA have a similar fingerprint on the hydrologic cycle of SA (Fig. 5). Both modes are characterized by a significant reduction in precipitation over much of the Amazon basin during their positive phase, with the amplitude of the changes associated with TNA forcing being slightly larger. This negative precipitation anomaly is as- 
Table 2. Comparison of PAGES-2k criteria with criteria implemented in this study.

\begin{tabular}{llll}
\hline Criteria & PAGES-2k & This paper & Criteria abbreviations for Table 3 \\
\hline A & $\begin{array}{l}\text { Described in peer-reviewed } \\
\text { publication }\end{array}$ & $\begin{array}{l}\text { Described in peer-reviewed } \\
\text { publication }\end{array}$ & \\
\hline B & Resolution $\leq 50 \mathrm{yr}$ & Resolution $\leq 300 \mathrm{yr}$ & (not specified) \\
\hline 1 & $\begin{array}{l}\text { Minimum duration of } \\
\text { record } \geq 500 \mathrm{yr}\end{array}$ & $\begin{array}{l}\text { Minimum duration of } \\
\text { record } \geq 500 \mathrm{yr}\end{array}$ & DUR500 \\
\hline 2 & Not specified & $\begin{array}{l}\text { More than two chronological tie } \\
\text { points within the last 2 kyr }\end{array}$ & CONTROL2 \\
\hline 3 & $\begin{array}{l}\text { Tie points near the end part } \\
\text { (most recent) of the records and } \\
\text { one near the oldest part }\end{array}$ & $\begin{array}{l}\text { Tie points near the end part } \\
\text { (most recent) of the records and } \\
\text { one near the oldest part }\end{array}$ & TOP_END \\
\hline 4 & $\begin{array}{l}\text { Records longer than 1 kyr must } \\
\text { include a minimum of one addi- } \\
\text { tional age midway between the } \\
\text { other two. }\end{array}$ & $\begin{array}{l}\text { Records longer than 1 kyr must } \\
\text { include minimum of one addi- } \\
\text { tional age midway between the } \\
\text { other two. }\end{array}$ & \\
\hline
\end{tabular}

sociated with the northward displacement of convective activity in the ITCZ region due to warmer SST in the tropical North Atlantic and Caribbean during the positive phase of the TNA (and to a lesser extent also the AMO). This directly affects precipitation amounts over NE Brazil (e.g. Hastenrath and Greischar, 1993; Nobre and Shukla, 1996), while the northward shift in the core region of convection also leads to anomalous subsidence, located over the Amazon basin. In fact the recent droughts in 2005 and 2010 in the Amazon basin were both associated with such anomalously warm SST in the tropical N Atlantic (Marengo et al., 2008; Lewis et al., 2011). The only region where precipitation is enhanced is in the northwestern part of the Amazon, belonging to Venezuela, Colombia, and Peru (Fig. 4).

An anomalously warm tropical S Atlantic (positive phase of the TSA) leads to the exact opposite conditions, with the ITCZ displaced anomalously far south, causing copious rainfall over NE Brazil, with weaker positive anomalies extending inland as far as the Peruvian border (Fig. 5). Another region of enhanced precipitation is located in S Brazil, associated with a southerly movement of the SACZ (Fig. 1; e.g. Doyle and Barros, 2002).

\section{Selection of pollen records for $\mathbf{2}$ ka}

Within the working groups of PAGES, the " $2 \mathrm{k}$ Network" was initially established in 2008 to improve current understanding of temperature variability across the Earth during the last 2 kyr. To collate records across the Earth for this time period systematically a set of criteria that defined the suitability of individual records was required. The principle of the criteria was to ensure, as far as possible, consistency (and therefore comparability) in the chronological control and sam- pling resolution of fossil pollen records (Table 2). Of the six PAGES-2k criteria within this paper, we regarded criterion $\mathrm{A}$ (peer-reviewed publication) as the base line criterion (all sites considered are from peer-reviewed studies). However, implementation of criterion $\mathrm{B}$ (resolution $\leq 50$ years) was not possible for SA because such a criterion would leave only a handful of pollen records to discuss. The sparsity of samples that meet the stringent PAGES-2k resolution criterion occurs because sedimentary archives with long time spans (> $10000 \mathrm{yr}$ ) are typically sampled at coarser temporal resolution. Furthermore, many lowland sites have slow sedimentation rates, which preclude high-resolution sampling. Therefore, we propose a more flexible temporal resolution, depending on the identified relevance of the case study.

From the newly updated Latin American Pollen Database (LAPD; Flantua et al., 2015), we initially selected all records that cover the last $2 \mathrm{kyr}$ (Fig. 6). Good chronological control is required for PAGES-2k, but the youngest ages in pollen records are typically constrained by geochronological data. An assessment of the pollen records by the authors with expertise in each SA subregion has revealed 585 records with pollen samples within the last 2 kyr (Fig. 6), of which 337 and 182 records, respectively, contain one or more geochronological dates within that time period. In total, 182 studies were checked to confirm their suitability for palaeoclimate reconstruction as outlined by the PAGES-2k criteria. Records with a resolution of 200 to $300 \mathrm{yr}$ are included in our discussion, while records along coastlines influenced by sea level changes were not included. Within the regional assessments, only records that fulfil more than three criteria are discussed, unless the records are considered particularly valuable for regional climate assessments. 


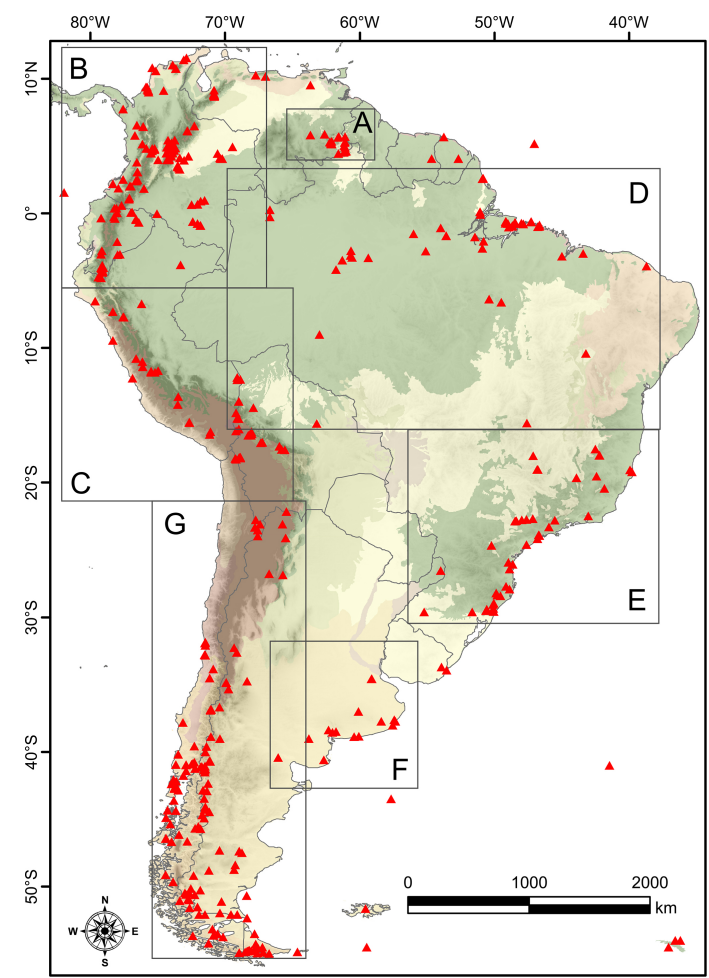

Figure 6. Map showing the location of LAPD pollen records that cover the last $2 \mathrm{kyr}$ (after Flantua et al., 2015). General regional delimitations as discussed in this paper are shown; A: Venezuelan Guayana highlands and uplands; B: Northern Andes; C: Central Andes; D: lowland Amazon basin; E: southern and southeastern Brazil; F: pampean plain; G: Southern Andes and Patagonia.

\section{Results}

\subsection{Regional assessments}

Pollen records are discussed according to their regional and geographical settings (Fig. 6): A - Venezuelan Guayana highlands and uplands (for the purposes of this study, we have defined this region as "Guayana" (different from "Guiana") following Huber's criteria $(1995 a, b)$ in the reference botanical guide to the "Flora of the Venezuelan Guayana"); B - Northern Andes; C - Central Andes; D - lowland Amazon basin; E - southern and southeastern Brazil; F - pampean plain; G - Southern Andes and Patagonia. The references to all records discussed are presented in Table 3.

\subsection{Climate-vegetation interaction in the Venezuelan Guayana highlands and uplands}

The study area, also known as the Gran Sabana (GS), is located in SE Venezuela between the Orinoco and Amazon basins (Fig. 6 Box A; Huber and Febres, 2000). Huber (1995a) recognized three main elevational levels on the Venezuelan Guayana: lowlands $(0-500 \mathrm{~m}$ above sea level, $\mathrm{m}$ a.s.1.), uplands (500-1500 $\mathrm{m}$ a.s.1.), and highlands (1500-3000 m a.s.l.). Lowlands are absent in the GS, which is mainly characterized by a continuous upland peneplain spiked with isolated highlands (table mountains, "tepuis"). The GS highlands are part of the so-called Pantepui phytogeographical province, which is characterized by unique biodiversity and endemism patterns, encompassing all the tepui summits above $1500 \mathrm{~m}$ a.s.l. (Huber, 1994; Berry et al., 1995). The tepuian vegetation is characterized by a mosaic of bare rock, pioneer vegetation, tepuian forests, herbaceous formations, and shrublands (Huber, 1995b). Additional background information is provided in the Supplement.

In the GS, 22 pollen records cover the last $2 \mathrm{kyr}$. There are four records with a chronology based on one control point and an additional 10 records for which most, or all, control points are older than $2 \mathrm{ka}$. Three potentially suitable records originate from the highlands - Eruoda PATAM6-A07, Churí Chim-2 and Apakará PATAM9-A07 - and only one is found in the uplands: Laguna Encantada PATAM4-D07 peatland (Fig. 7a; Table 3). Of the three records of the highlands, just Eruoda provides sufficiently high resolution to explore the objectives proposed here. However, only Churí Chim-2 and Apakará contain several age control points within the last 2 kyr, and Laguna Encantada presents a relatively low sampling resolution of 200 to $300 \mathrm{yr}$.

The criteria for chronological control excluded some of the most relevant work for the research questions posed by this paper. For example, the vegetation at the Eruoda summit has persisted unchanged during the last $\sim 2.5 \mathrm{kyr}$. This constancy can be extended to all the tepuian summits studied so far for the last $6 \mathrm{kyr}$ (except Churí). Equally of high importance is the Urué record in the uplands, which does not meet the dating control constraints, but the sampling resolution is high enough to provide important insights into the vegetation-climate dynamics during the last $2 \mathrm{kyr}$, and will be therefore be presented here.

The Eruoda summit represents an important reference to which almost all the tepuian summit vegetation dynamics can be compared (Fig. 7b). Based on the absence of human activities in these summits, it can be assumed that the vegetation dynamics observed in the fossil records are fully climate driven and therefore valuable for LOTRED-SA. In general, these summits are insensitive to temperature change (for $2 \mathrm{ka}$ ), whereas moisture variations potentially may cause small internal reorganizations of plant associations although these shifts are considered to be of minor ecological significance. Shifting river courses are considered to influence local vegetation patterns through the lateral movement of gallery forests in landscapes (Rull, 2005a, b).

The Urué sequence spans the last $1.6 \mathrm{kyr}$ and records the vegetation dynamics after an important fire event dated $\sim 1.6-1.8 \mathrm{ka}$. Three main vegetation stages were reported coeval with high charcoal abundances at the bottom of the sequence, corresponding to plant communities' transitions from open secondary forest to fern-dominated associa- 
Table 3. List of pollen records used and metadata.

\begin{tabular}{|c|c|c|c|c|c|c|c|c|c|c|}
\hline Fig. 6 & Region & LAPD ID & Site name & $\begin{array}{l}\text { Potentially } \\
\text { suitable for } \\
2 \text { ka climate } \\
\text { modelling }\end{array}$ & $\begin{array}{l}\text { Potentially } \\
\text { suitable for } \\
\text { human stud- } \\
\text { ies }\end{array}$ & LOTRED- $2 \mathrm{k}$ & DUR 500 & CONTROL2 & TOP_END & 1000_MID3 \\
\hline A & Ven.Gui & 1638 & Laguna Encantada PATAM4-D 7 & Yes & & 4 & 1 & 1 & 1 & 1 \\
\hline A & Ven.Gui & 1247 & Eruoda PATAM6-A 7 & Yes & & 1 & 1 & & & \\
\hline A & Ven.Gui & 1606 & Churí Chim-2 & Yes & & 2 & 1 & 1 & & \\
\hline A & Ven.Gui & 1582 & Apakará PATAM9-A 7 & Yes & & 3 & 1 & 1 & 1 & \\
\hline A & Ven.Gui & 1684 & Urué & Yes & Yes & 1 & 1 & & & \\
\hline A & Ven.Gui & 1646 & Lake Chonita PARAM1-B 7 & & Yes & 1 & 1 & & & \\
\hline A & Ven.Gui & 1611 & El Paují PATAM5-A 7 & & Yes & 1 & 1 & & & \\
\hline B & $\mathrm{N}$ Andes & 1648 & Lake Valencia 76V 1-5 & Yes & Yes & 4 & 1 & 1 & 1 & 1 \\
\hline B & $\mathrm{N}$ Andes & 1665 & Piedras Blancas & Yes & & 2 & 1 & 1 & & \\
\hline B & N Andes & 892 & Fúquene-2 & & Yes & 1 & 1 & & & \\
\hline B & $\mathrm{N}$ Andes & 899 & Pantano de Genagra & & Yes & 1 & 1 & & & \\
\hline B & N Andes & 851 & Carimagua Bosque & Yes & Yes & 4 & 1 & 1 & 1 & 1 \\
\hline B & N Andes & 938 & Las Margaritas & Yes & Yes & 3 & 1 & 1 & 1 & \\
\hline B & $\mathrm{N}$ Andes & 941 & Loma Linda & & Yes & 3 & 1 & 1 & 1 & \\
\hline B & $\mathrm{N}$ Andes & 907 & Jotaordó & Yes & Yes & 4 & 1 & 1 & 1 & 1 \\
\hline B & $\mathrm{N}$ Andes & 877 & El Caimito & Yes & Yes & 4 & 1 & 1 & 1 & 1 \\
\hline B & $\mathrm{N}$ Andes & 901 & Guandal & Yes & Yes & 3 & 1 & 1 & 1 & \\
\hline B & N Andes & 935 & Piusbi & & Yes & 4 & 1 & 1 & 1 & 1 \\
\hline B & $\mathrm{N}$ Andes & 910 & La Cocha-1 & Yes & Yes & 4 & 1 & 1 & 1 & 1 \\
\hline B & N Andes & 1867 & Reserve Guandera-G15 & Yes & Yes & 2 & 1 & 1 & & \\
\hline B & $\mathrm{N}$ Andes & 1176 & Reserve Guandera-G8 & Yes & Yes & 4 & 1 & 1 & 1 & 1 \\
\hline B & $\mathrm{N}$ Andes & 1751 & Laguna Daniel Álvarez & & Yes & 3 & 1 & 1 & 1 & \\
\hline B & N Andes & 1158 & Laguna Pallcacocha 1 & Yes & & 4 & 1 & 1 & 1 & 1 \\
\hline B & $\mathrm{N}$ Andes & 2143 & Papallacta PA 1- 8 & Yes & & 4 & 1 & 1 & 1 & 1 \\
\hline B & $\mathrm{N}$ Andes & 1181 & Tres Lagunas & Yes & Yes & 4 & 1 & 1 & 1 & 1 \\
\hline B & $\mathrm{N}$ Andes & 1160 & Laguna Zurita & & Yes & 3 & 1 & 1 & 1 & \\
\hline B & $\mathrm{N}$ Andes & 1749 & ECSF Refugio & Yes & & 3 & 1 & 1 & 1 & \\
\hline B & $\mathrm{N}$ Andes & 1144 & El Junco EJ1 & & Yes & 3 & 1 & 1 & 1 & \\
\hline $\mathrm{C}$ & C Andes & 2518 & Cerro Llamoca & Yes & & 4 & 1 & 1 & 1 & 1 \\
\hline $\mathrm{C}$ & C Andes & 1520 & Marcacocha & Yes & Yes & 4 & 1 & 1 & 1 & 1 \\
\hline $\mathrm{C}$ & C Andes & 1496 & Chicha-Soras & Yes & Yes & 4 & 1 & 1 & 1 & 1 \\
\hline $\mathrm{C}$ & C Andes & 1516 & Pacucha & Yes & Yes & 4 & 1 & 1 & 1 & 1 \\
\hline $\mathrm{C}$ & C Andes & 1514 & Consuelo & Yes & & 2 & 1 & 1 & & \\
\hline $\mathrm{C}$ & C Andes & 1555 & Urpi Kocha Lagoon Core 2 & Yes & Yes & 4 & 1 & 1 & 1 & 1 \\
\hline $\mathrm{C}$ & C Andes & 1546 & Nevado Coropuna & & Yes & 2 & 1 & 1 & & \\
\hline $\mathrm{D}$ & Amazon & 1211 & Quistococha & Yes & & 4 & 1 & 1 & 1 & 1 \\
\hline $\mathrm{D}$ & Amazon & 1558 & Werth & Yes & & 4 & 1 & 1 & 1 & 1 \\
\hline $\mathrm{D}$ & Amazon & 2991 & Laguna Granja & & Yes & 4 & 1 & 1 & 1 & 1 \\
\hline $\mathrm{D}$ & Amazon & 460 & Fazenda Cigana & Yes & Yes & 4 & 1 & 1 & 1 & 1 \\
\hline $\mathrm{D}$ & Amazon & 3004 & French Guiana K-VIII & Yes & Yes & 4 & 1 & 1 & 1 & 1 \\
\hline $\mathrm{D}$ & Amazon & 1498 & Gentry & & Yes & 1 & 1 & & & \\
\hline $\mathrm{D}$ & Amazon & 1549 & Parker & & Yes & 1 & 1 & & & \\
\hline $\mathrm{D}$ & Amazon & 518 & Lake Geral core $\mathrm{C}$ & & Yes & 1 & 1 & & & \\
\hline
\end{tabular}

tions transitional to savanna. Savannas were fully established around $0.9 \mathrm{ka}$, coinciding with the beginning of a phase of lower charcoal values, and continued as the dominant plant association until the present day. Savannas were accompanied by Mauritia flexuosa palm swamps ("morichales"), which established a phase that was likely more humid. These palm swamps varied greatly in extent through time, showing a parallel between the lowest palm abundance and the occurrence of two drought intervals. These two drought intervals were centred on $0.65-0.55$ and $0.15-0.05 \mathrm{ka}$, coeval with the Little Ice Age (LIA) signal observed in the Venezuelan Andes (Rull et al., 1987; Rull and Schubert, 1989; Polissar et al., 2006). Generally, the vegetation dynamics recorded so far in the Venezuelan Guayana uplands have shown a higher sensitivity to changes in the available moisture than to potential shifts in the average temperatures. The last $2 \mathrm{kyr}$ have been mainly characterized by vegetation change on a local scale.

\subsection{Climate-vegetation interaction in the Northern Andes}

The region of the $\mathrm{N}$ Andes consists in political terms of Colombia, Ecuador, and Venezuela and includes a wide range of different ecoregions (Fig. 6 Box B). Sharing both the Caribbean and the Pacific coastline and various climate influences, Colombia has a unique pattern of different ecosystems shared with neighbouring countries. Pollen records are found throughout a wide range of biomes and elevations (Flantua et al., 2015), from the tropical rainforest and mangroves along the coast to the high Andean "páramos". The complex formation of the Andes with the three mountain ridges characterizes this region with numerous valleys and watersheds.

A total of 64 records are available that present pollen data within the last $2 \mathrm{kyr}$. Unfortunately, 14 were presented in publications without a peer-review procedure or presented only as a summary diagram ( 7 records with 4 positive cri- 
Table 3. Continued.

\begin{tabular}{|c|c|c|c|c|c|c|c|}
\hline Fig. 6 & Region & LAPD ID & Site name & Human indicators & $\begin{array}{l}\text { First human } \\
\text { indicator } \\
\text { (calyr BP) }\end{array}$ & $\begin{array}{l}\text { Precip. } \\
\text { sensitive }\end{array}$ & $\begin{array}{l}\text { Temp. } \\
\text { sensitive }\end{array}$ \\
\hline A & Ven.Gui & 1638 & Laguna Encantada PATAM4-D07 & Fire, Mauritia(?) & 1200 & Yes & \\
\hline A & Ven.Gui & 1247 & Eruoda PATAM6-A07 & No & & Yes & \\
\hline A & Ven.Gui & 1606 & Churí Chim-2 & No & & Yes & Yes \\
\hline A & Ven.Gui & 1582 & Apakará PATAM9-A07 & No & & Yes & \\
\hline A & Ven.Gui & 1684 & Urué & Possible fire increase & 2000 & Yes & \\
\hline A & Ven.Gui & 1646 & Lake Chonita PARAM1-B07 & Mauritia, fire increase & 2000 & Yes & \\
\hline A & Ven.Gui & 1611 & El Paují PATAM5-A07 & Forest composition change, fire increase & $>2000$ & Yes & \\
\hline B & N Andes & 1648 & Lake Valencia 76V 1-5 & No & & & \\
\hline B & $\mathrm{N}$ Andes & 1665 & Piedras Blancas & No & & & \\
\hline B & N Andes & 0892 & Fúquene-2 & Increase Asteraceae, Poaceae & 3000 & & \\
\hline B & N Andes & 0899 & Pantano de Genagra & $\begin{array}{l}\text { Deforestation, pollen of Z. mays, Spermacoce, Chen-Am; spores of Grammitis- } \\
\text { type and Anthoceros }\end{array}$ & 2300 & & Yes \\
\hline B & $\mathrm{N}$ Andes & 0851 & Carimagua Bosque & Mauritiella, savanna, Cecropia increase & 200 & Yes & \\
\hline B & $\mathrm{N}$ Andes & 0938 & Las Margaritas & Savanna increase & & & \\
\hline B & N Andes & 0941 & Loma Linda & Savanna increase & & Yes & \\
\hline B & N Andes & 0907 & Jotaordó & Zea mays and palm increase & 1000 & Yes & \\
\hline B & $\mathrm{N}$ Andes & 0877 & El Caimito & Cecropia and palm trees (Arecaceae) & 580 & Yes & \\
\hline B & N Andes & 0901 & Guandal & Cecropia, Vismia, other indicators of swamps intervening & 600 & Yes & \\
\hline B & $\mathrm{N}$ Andes & 935 & Piusbi & Zea mays & 1800 & Yes & \\
\hline B & N Andes & 0910 & La Cocha & $\begin{array}{l}\text { Logging, preferentially Podocarpus, frequent fires, forest disturbance and } \\
\text { changes in the diatom flora. }\end{array}$ & $1405-1100$ & Yes & Yes \\
\hline B & $\mathrm{N}$ Andes & 1867 & Reserve Guandera-G15 & Rumex & 100 & Yes & \\
\hline B & N Andes & 1176 & Reserve Guandera-G8 & Dodonaea presence & 300 & & \\
\hline B & $\mathrm{N}$ Andes & 1751 & Laguna Daniel Álvarez & Zea mays & 1400 & & \\
\hline B & N Andes & 1158 & Laguna Pallcacocha 1 & No & & Yes & \\
\hline B & N Andes & 2143 & Papallacta PA 1-08 & No & & Yes & \\
\hline B & $\mathrm{N}$ Andes & 1181 & Tres Lagunas & Zea mays & 300 & & \\
\hline B & $\mathrm{N}$ Andes & 1160 & Laguna Zurita & Zea mays & 900 & & \\
\hline B & N Andes & 1749 & ECSF Refugio & $\begin{array}{l}\text { Decrease in Isoetes and Cyperaceae (due to moisture increase or humans), } \\
\text { Z. mays ( } 800 \text { cal yr) }\end{array}$ & 1200 & & \\
\hline B & $\mathrm{N}$ Andes & 1144 & El Junco EJ1 & No & & & \\
\hline $\mathrm{C}$ & C Andes & 2518 & Cerro Llamoca & No & & Yes & \\
\hline $\mathrm{C}$ & C Andes & 1520 & Marcacocha & Zea mays & 2700 & Yes & Yes \\
\hline $\mathrm{C}$ & C Andes & 1496 & Chicha-Soras & Chen-Am (expansion Quinoa crops?) & 1000 & & \\
\hline $\mathrm{C}$ & C Andes & 1516 & Pacucha & Zea mays & 5500 & Yes & \\
\hline $\mathrm{C}$ & C Andes & 1514 & Consuelo & No & & Yes & \\
\hline $\mathrm{C}$ & C Andes & 1555 & Urpi Kocha Lagoon Core 2 & Zea mays & $>2000$ & & \\
\hline $\mathrm{C}$ & C Andes & 1546 & Nevado Coropuna & Zea mays, Ambrosia (terrace consolidator) & 2200 & Yes & Yes \\
\hline $\mathrm{D}$ & Amazon & 1211 & Quistococha & No & & & \\
\hline D & Amazon & 1558 & Werth & No & & Yes & \\
\hline D & Amazon & 2991 & Laguna Granja & Z. mays, charcoal & 2500 & Yes? & \\
\hline D & Amazon & 0460 & Fazenda Cigana & Charcoal, forest decrease, savanna increase & $>2000 ?$ & Yes & \\
\hline $\mathrm{D}$ & Amazon & 3004 & French Guiana K-VIII & Z. mays, Manihot esculenta, Crantz and Ipomoea batatas & $800-200$ & Yes & \\
\hline D & Amazon & 1498 & Gentry & Z. mays, Manihot esculenta, Cecropia & ca. $3500-500$ & & \\
\hline D & Amazon & 1549 & Parker & Cyperaceae, charcoal & ca. 2800 & Yes & \\
\hline D & Amazon & 0518 & Lake Geral core C & Z. mays, Cecropia, Gramineae, charcoal (?) & $\begin{array}{l}\text { ca. } 3350 \\
(\text { ca. } 5500)\end{array}$ & Yes & \\
\hline
\end{tabular}

teria). An additional five records, which fulfilled all criteria, suggested human presence from before $2 \mathrm{ka}$ and were therefore excluded for climate reconstructions. From the remaining records, only four lakes lack human interference during the last 2 kyr. The others describe human indicators over limited periods of time and are considered valuable for PAGES$2 \mathrm{k}$ purposes (Table 3 ).

Lake Valencia (Figs. 6 Box B and 8a) is represented by three cores with varying quality in chronology and resolution. The last $2 \mathrm{kyr}$ are characterized by a decline in forest cover, which attains the lowest values of the Holocene and gives way to savannas. Aquatic proxies indicate declining lake levels and increasing nutrient input, a trend that accelerated during the last $0.5 \mathrm{kyr}$, when human activities were more intense around the lake. Considering the entire Lateglacial-Holocene record, the Lake Valencia catchment has been shown to be more sensitive to moisture variations than to temperature, as known from tropical lowlands.
In the Andean region, changes in the altitudinal position of the upper forest line (UFL) are instrumental in reconstructing temperature changes. This ecotone is defined as the highest elevation contour of continuous forest and marks the boundary between the forest and the high Andean páramo biome (Moscol-Olivera and Hooghiemstra, 2010; Groot et al., 2013). The Andean sites in Venezuela and Colombia show indications of colder climates by decreased arboreal pollen at higher elevations. In the Venezuelan Andes, the only available pollen record is Piedras Blancas. There is no indication of human activity; hence, changes should be attributed mostly to climatic shifts, notably temperature and moisture. The expansion of superpáramo vegetation suggests a response to the warm and moist Medieval Climate Anomaly (MCA; $\sim 1.15-0.65 \mathrm{ka}$ ), while a period of scarce vegetation might be related to the LIA $(\sim 0.6-0.1 \mathrm{ka})$ (Ledru et al., 2013a). The absence of tree pollen in several samples indicates significantly depressed UFL in comparison to today. 
Table 3. Continued.

\begin{tabular}{|c|c|c|c|c|c|c|}
\hline Fig. 6 & Region & LAPD ID & Site name & References & $\begin{array}{l}\text { Latitude } \\
\text { (decimal } \\
\text { degrees) }\end{array}$ & $\begin{array}{l}\text { Longitude } \\
\text { (decimal } \\
\text { degrees) }\end{array}$ \\
\hline A & Ven.Gui & 1638 & Laguna Encantada PATAM4-D07 & Montoya et al. (2009) & 4.60 & -61.11 \\
\hline A & Ven.Gui & 1247 & Eruoda PATAM6-A07 & Nogue et al. (2009) & 5.37 & -62.08 \\
\hline A & Ven.Gui & 1606 & Churí Chim-2 & Rull $(1991,2004 a, b)$ & 5.32 & -62.17 \\
\hline A & Ven.Gui & 1582 & Apakará PATAM9-A07 & Rull et al. (2011) & 5.32 & -62.23 \\
\hline A & Ven.Gui & 1684 & Urué & Rull $(1991,1999)$ & 5.03 & -61.17 \\
\hline A & Ven.Gui & 1646 & Lake Chonita PARAM1-B07 & Montoya et al. (2011a) & 4.65 & -61.00 \\
\hline A & Ven.Gui & 1611 & El Paují PATAM5-A07 & Montoya et al. (2011b) & 4.28 & -61.35 \\
\hline B & $\mathrm{N}$ Andes & 1648 & Lake Valencia 76V 1-5 & Leyden (1985) & 10.18 & -67.01 \\
\hline B & $\mathrm{N}$ Andes & 1665 & Piedras Blancas & Rull et al. (1987) & 9.17 & -70.83 \\
\hline B & $\mathrm{N}$ Andes & 0892 & Fúquene-2 & Van Geel and Van der Hammen (1973) & 5.45 & -73.77 \\
\hline B & $\mathrm{N}$ Andes & 0899 & Pantano de Genagra & Behling et al. (2001) & 2.47 & -76.62 \\
\hline B & $\mathrm{N}$ Andes & 0851 & Carimagua Bosque & Berrio et al. (2000) & 4.07 & -70.22 \\
\hline B & $\mathrm{N}$ Andes & 0938 & Las Margaritas & Wille et al. (2003) & 3.38 & -73.43 \\
\hline B & $\mathrm{N}$ Andes & 0941 & Loma Linda & Behling and Hooghiemstra (2000) & 3.30 & -73.38 \\
\hline B & N Andes & 0907 & Jotaordó & Berrio et al. (2000), Urrego and Berrio (2011) & 5.80 & -76.70 \\
\hline B & N Andes & 0877 & El Caimito & Velez et al. (2001) & 2.53 & -77.60 \\
\hline B & $\mathrm{N}$ Andes & 0901 & Guandal & Urrego and del Valle (2002) & 2.22 & -78.35 \\
\hline B & $\mathrm{N}$ Andes & 935 & Piusbi & Behling et al. (1998a) & 1.90 & -77.94 \\
\hline B & N Andes & 0910 & La Cocha-1 & Gonzalez-Carranza et al. (2012) & 1.06 & -77.15 \\
\hline B & $\mathrm{N}$ Andes & 1867 & Reserve Guandera-G15 & Bakker et al. (2008) & 0.60 & -77.70 \\
\hline B & N Andes & 1176 & Reserve Guandera-G8 & Moscol Olivera and Hooghiemstra (2010) & 0.60 & -77.70 \\
\hline B & $\mathrm{N}$ Andes & 1751 & Laguna Daniel Álvarez & Niemann et al. (2013) & -4.02 & -79.21 \\
\hline B & N Andes & 1158 & Laguna Pallcacocha 1 & Rodbell et al. (1999) & -4.77 & -79.23 \\
\hline B & N Andes & 2143 & Papallacta PA 1-08 & Ledru et al. (2013) & -0.36 & -78.19 \\
\hline B & $\mathrm{N}$ Andes & 1181 & Tres Lagunas & Jantz and Behling (2012) & -3.03 & -79.23 \\
\hline B & $\mathrm{N}$ Andes & 1160 & Laguna Zurita & Niemann and Behling (2010) & -3.03 & -79.23 \\
\hline B & N Andes & 1749 & ECSF Refugio & Niemann and Behling (2010) & -3.99 & -79.07 \\
\hline B & N Andes & 1144 & El Junco EJ1 & Colinvaux and Schofield (1976) & -0.50 & -91.00 \\
\hline $\mathrm{C}$ & C Andes & 2518 & Cerro Llamoca & Schittek et al. (2015) & -14.17 & -74.73 \\
\hline $\mathrm{C}$ & C Andes & 1520 & Marcacocha & Chepstow-Lusty et al. $(1998,2003,2009)$ & -11.39 & -76.12 \\
\hline $\mathrm{C}$ & C Andes & 1496 & Chicha-Soras & Branch et al. (2007) & -14.18 & -73.53 \\
\hline $\mathrm{C}$ & C Andes & 1516 & Pacucha & Hillyer et al. (2009), Valencia et al. (2010) & -13.61 & -73.50 \\
\hline $\mathrm{C}$ & C Andes & 1514 & Consuelo & Urrego et al. (2010) & -13.95 & -69.00 \\
\hline $\mathrm{C}$ & C Andes & 1555 & Urpi Kocha Lagoon Core 2 & Winsborough et al. (2012) & -12.23 & -76.88 \\
\hline $\mathrm{C}$ & C Andes & 1546 & Nevado Coropuna & Kuentz et al. (2012) & -15.50 & -72.67 \\
\hline $\mathrm{D}$ & Amazon & 1211 & Quistococha & Roucoux et al. (2013) & -3.83 & -73.32 \\
\hline D & Amazon & 1558 & Werth & Bush et al. $(2007 a, b)$ & -12.18 & -69.10 \\
\hline $\mathrm{D}$ & Amazon & 2991 & Laguna Granja & Carson et al. (2014) & -13.26 & -63.71 \\
\hline $\mathrm{D}$ & Amazon & 0460 & Fazenda Cigana & Da Silva Menenses et al. (2013) & -3.45 & -61.30 \\
\hline D & Amazon & 3004 & French Guiana K-VIII & Iriarte et al. (2012) & 5.20 & -52.69 \\
\hline D & Amazon & 1498 & Gentry & Bush et al. $(2007 a, b)$ & -12.33 & -68.87 \\
\hline $\mathrm{D}$ & Amazon & 1549 & Parker & Bush et al. $(2007 a, b)$ & -12.18 & -69.10 \\
\hline $\mathrm{D}$ & Amazon & 0518 & Lake Geral core C & Bush et al. $(2000,2007 b)$ & -1.65 & -53.60 \\
\hline
\end{tabular}

Along the transitional zone between savanna and tropical rainforest in the east (E) Colombian savannas, three pollen records fulfil at least three criteria. Since $2 \mathrm{ka}$, a gradual increase in savanna vegetation is observed, suggesting a period of progressively drier conditions, e.g. at Loma Linda and Las Margaritas). However, the expanding Mauritia palm forest observed in several records is considered to reflect increased local water availability and precipitation (Fig. 8b), and/or human impact (Behling and Hooghiemstra, 1998, 1999; Rull and Montoya, 2014).

Along the N Andean Pacific slopes, Jotaordó, El Caimito, Guandal, and Piusbi document vegetation changes related to the precipitation regime in the $\mathrm{C}$ and $\mathrm{S}$ Chocó biogeographic region. Settings differ, as the first is located in a broad river valley with a meandering drainage system, while El Caimito and Guandal are located in the coastal plain receiving signals from shifting mangrove forests. These shifts were considered not to be climate related but explained by tectonic events in the region and/or dynamic shifts of the river deposition patterns. Frequent erosion events, various seismic shifts and disturbance indicators of mixed origin during the last $2 \mathrm{kyr}$ hinder consistent conclusions for the region. Changes in vegetation composition around $0.65 \mathrm{ka}$ were assigned in El Caimito to reduced flooding and possible human intervention, while similar changes at Jotaordó were ascribed to endogenous dynamics. Only the multi-proxy approach of El Caimito suggests a possible relationship between periods of higher riverine dynamics and the frequency of long-term ENSO variabil- 
Table 3. Continued.

\begin{tabular}{|c|c|c|c|c|c|c|c|c|c|c|}
\hline Fig. 6 & Region & LAPD ID & Site name & $\begin{array}{l}\text { Potentially } \\
\text { suitable for } \\
2 \text { kyr climate } \\
\text { modelling }\end{array}$ & $\begin{array}{l}\text { Potentially } \\
\text { suitable for } \\
\text { human stud- } \\
\text { ies }\end{array}$ & LOTRED-2 k & DUR 500 & CONTROL2 & TOP_END & 1000_MID3 \\
\hline $\mathrm{D}$ & Amazon & 599 & Terra Indigena Aningal & Yes & Yes & 3 & 1 & 1 & 1 & \\
\hline $\mathrm{D}$ & Amazon & 1557 & Vargas & Yes & Yes & 2 & 1 & 1 & & \\
\hline $\mathrm{D}$ & Amazon & 2993 & Laguna El Cerrito & & Yes & 3 & 1 & 1 & & 1 \\
\hline $\mathrm{D}$ & Amazon & 2994 & Laguna Frontera & & Yes & 3 & 1 & 1 & & 1 \\
\hline $\mathrm{D}$ & Amazon & 2995 & Laguna San José & & Yes & 3 & 1 & 1 & & 1 \\
\hline $\mathrm{D}$ & Amazon & 339 & Laguna Chaplin & & Yes & 1 & 1 & & & \\
\hline $\mathrm{D}$ & Amazon & 566 & Rio Curua & & Yes & 1 & 1 & & & \\
\hline $\mathrm{D}$ & Amazon & 521 & Lake Tapera & & Yes & 2 & 1 & 1 & & \\
\hline $\mathrm{D}$ & Amazon & 483 & Lago Crispim & & Yes & 1 & 1 & & & \\
\hline $\mathrm{D}$ & Amazon & 1166 & Maxus-1 & Yes & & 3 & 1 & 1 & & 1 \\
\hline $\mathrm{E}$ & SE Brazil & 582 & São José dos Ausentes & & Yes & 4 & 1 & 1 & 1 & 1 \\
\hline E & SE Brazil & 3005 & Morro Santana & & Yes & 4 & 1 & 1 & 1 & 1 \\
\hline E & SE Brazil & 1998 & Rincão das Cabritas & Yes & Yes & 3 & 1 & 1 & 1 & \\
\hline $\mathrm{E}$ & SE Brazil & 437 & Cambará do Sul & Yes & Yes & 2 & 1 & 1 & & \\
\hline E & SE Brazil & 591 & Serra dos Órgãos & Yes & & 1 & 1 & & & \\
\hline E & SE Brazil & 479 & Lagoa Nova & & Yes & 1 & 1 & & & \\
\hline E & SE Brazil & 1962 & Ciama 2 & Yes & Yes & 1 & 1 & & & \\
\hline E & SE Brazil & 487 & Lago do Pires & Yes & Yes & 1 & 1 & & & \\
\hline E & SE Brazil & 579 & Saõ Francisco de Assis & & Yes & 1 & 1 & & & \\
\hline $\mathrm{F}$ & Pampas & 2998 & Hinojales-San Leoncio & & Yes & 2 & 1 & 1 & & \\
\hline $\mathrm{F}$ & Pampas & 2423 & Lake Lonkoy & Yes & Yes & 4 & 1 & 1 & 1 & 1 \\
\hline $\mathrm{F}$ & Pampas & 216 & Laguna Sauce Grance & Yes & & 3 & 1 & 1 & 1 & \\
\hline G & S Andes and Patagonia & 745 & Onamonte & Yes & & 4 & 1 & 1 & 1 & 1 \\
\hline G & S Andes and Patagonia & 50 & Puerto Harberton & Yes & & 4 & 1 & 1 & 1 & 1 \\
\hline G & $\mathrm{S}$ Andes and Patagonia & 242 & Valle de Andorra & Yes & & 4 & 1 & 1 & 1 & 1 \\
\hline G & S Andes and Patagonia & 1990 & Cabo Vírgenes & & Yes & 2 & 1 & 1 & & \\
\hline G & S Andes and Patagonia & 2996 & Cabo Vírgenes CV22 & & Yes & 2 & 1 & 1 & & \\
\hline G & $\mathrm{S}$ Andes and Patagonia & 83 & Laguna Azul & Yes & Yes & 4 & 1 & 1 & 1 & 1 \\
\hline G & S Andes and Patagonia & 792 & Río Rubens & & Yes & 4 & 1 & 1 & 1 & 1 \\
\hline G & $S$ Andes and Patagonia & 102 & Laguna Potrok Aike & & & 4 & 1 & 1 & 1 & 1 \\
\hline G & $\mathrm{S}$ Andes and Patagonia & 734 & Lago Cipreses & Yes & Yes & 4 & 1 & 1 & 1 & 1 \\
\hline G & S Andes and Patagonia & 50 & Lago Guanaco & Yes & Yes & 4 & 1 & 1 & 1 & 1 \\
\hline G & $S$ Andes and Patagonia & 25 & Cerro Frías & Yes & Yes & 2 & 1 & 1 & & \\
\hline $\mathrm{G}$ & S Andes and Patagonia & 3000 & Peninsula Avellanedo Bajo & Yes & & 4 & 1 & 1 & 1 & 1 \\
\hline G & S Andes and Patagonia & 2484 & Parque Nacional Perito Moreno & Yes & & 4 & 1 & 1 & 1 & 1 \\
\hline G & $\mathrm{S}$ Andes and Patagonia & 657 & Mallín Pollux & Yes & Yes & 4 & 1 & 1 & 1 & 1 \\
\hline $\mathrm{G}$ & S Andes and Patagonia & 1964 & Mallín El Embudo & Yes & Yes & 4 & 1 & 1 & 1 & 1 \\
\hline G & $S$ Andes and Patagonia & 1965 & Lago Shaman & Yes & Yes & 3 & 1 & & 1 & 1 \\
\hline G & $\mathrm{S}$ Andes and Patagonia & 99 & Lago Mosquito & Yes & Yes & 4 & 1 & 1 & 1 & 1 \\
\hline $\mathrm{G}$ & S Andes and Patagonia & 2501 & Lago Lepué & Yes & Yes & 4 & 1 & 1 & 1 & 1 \\
\hline G & $S$ Andes and Patagonia & 2321 & Lago Pichilafquen & Yes & Yes & 4 & 1 & 1 & 1 & 1 \\
\hline G & $S$ Andes and Patagonia & 2320 & Lago San Pedro & Yes & Yes & 4 & 1 & 1 & 1 & 1 \\
\hline $\mathrm{G}$ & S Andes and Patagonia & 661 & Laguna de Aculeo & Yes & Yes & 4 & 1 & 1 & 1 & 1 \\
\hline G & S Andes and Patagonia & 749 & Palo Colorado & Yes & & 4 & 1 & 1 & 1 & 1 \\
\hline G & S Andes and Patagonia & 2996 & Abra del Infiernillo & Yes & & 4 & 1 & 1 & 1 & 1 \\
\hline
\end{tabular}

ity. Within this region, Cecropia is used as natural disturbance indicator due to fluvial-marine dynamics, while in the other Colombian regions this fast-growing species is considered characteristic of human interference; both settings have disturbance as a common factor.

In the Colombian Andes there are no undisturbed pollen records during the last $2 \mathrm{kyr}$ suitable for climate reconstructions. Before the human disturbances, the La Cocha-1 record in the far south of Colombia (Fig. 8b) indicated generally wetter conditions similar to the $\mathrm{N}$ Ecuadorian pollen records of Guandera-G15 and Guandera-G8. A different kind of index to highlight vegetation-climate interaction was used in the E Ecuadorian Andes at Papallacta PA1-08. Established to characterize the SASM and ENSO, the index interprets cloud transported arboreal pollen grains and Poaceae as a proxy for upslope cloud convection. Supported by a high resolution $(\sim 15 \mathrm{yr})$, a high frequency of dry and humid episodes is detected during the last $1.1 \mathrm{kyr}$. In this alternation of con- vective activity, the MCA, LIA, and current warm period are considered detectable.

In S Ecuador four pollen records suitable for PAGES-2k purposes are found within a relatively small subregion. Tres Lagunas suggests a cold phase, possibly the LIA, as one of several warm and cold phases detected during the last $2 \mathrm{kyr}$ (Fig. 8b). At Laguna Zurita, the decrease in Isoetes was considered an indication of increased precipitation after $\sim 1.2 \mathrm{ka}$, observed similarly in other fossil pollen records in the C Peruvian Andes. On the other hand, chemical analyses from the same core suggested drier conditions during the last millennium, confirmed by a different set of palaeoclimatic records. Unknown human interference in the last millennium could be related to these divergent patterns, as the nearby ECSF Refugio and Laguna Daniel Álvarez detected Zea mays around 0.8 and $1.4 \mathrm{ka}$, respectively. 
Table 3. Continued.

\begin{tabular}{|c|c|c|c|c|c|c|c|}
\hline Fig. 6 & Region & LAPD ID & Site name & Human indicators & $\begin{array}{l}\text { First human } \\
\text { indicator } \\
\text { (cal yr BP) }\end{array}$ & $\begin{array}{l}\text { Precip. } \\
\text { sensitive }\end{array}$ & $\begin{array}{l}\text { Temp. } \\
\text { sensitive }\end{array}$ \\
\hline D & Amazon & 0599 & Terra Indigena Aningal & Charcoal, forest decrease, savanna increase & $>2000 ?$ & Yes & \\
\hline $\mathrm{D}$ & Amazon & 1557 & Vargas & Charcoal & 1000 & Yes & \\
\hline $\mathrm{D}$ & Amazon & 2993 & Laguna El Cerrito & Z. mays, charcoal & 2000 & & \\
\hline D & Amazon & 2994 & Laguna Frontera & Z. mays, charcoal & 2000 & & \\
\hline $\mathrm{D}$ & Amazon & 2995 & Laguna San José & Z. mays, charcoal & ca. 1600 & & \\
\hline D & Amazon & 0339 & Laguna Chaplin & Z. mays (unpubl.) & ca. 1300 & & \\
\hline $\mathrm{D}$ & Amazon & 0566 & Rio Curua & Charcoal, forest decrease & ca. 2500 & Yes & \\
\hline D & Amazon & 0521 & Lake Tapera & Charcoal & ca. 6900 & Yes & \\
\hline D & Amazon & 0483 & Lago Crispim & Charcoal, mangrove decrease & $>2000$ & & \\
\hline $\mathrm{D}$ & Amazon & 1166 & Maxus-1 & No & & Yes & \\
\hline E & SE Brazil & 0582 & São José dos Ausentes & Grasses, charcoal, Pinus & 500 & & \\
\hline $\mathrm{E}$ & SE Brazil & 3005 & Morro Santana & Charcoal, Z. mays, Pinus, Eucalyptus & 1230 & & \\
\hline E & SE Brazil & 1998 & Rincão das Cabritas & Grasses, fire increase (since early and mid-Holocene) & 30 & Yes & Yes \\
\hline $\mathrm{E}$ & SE Brazil & 0437 & Cambará do Sul & Charcoal, grasses & 170 & Yes & Yes \\
\hline E & SE Brazil & 0591 & Serra dos Órgãos & Charcoal (?) & & Yes & Yes \\
\hline E & SE Brazil & 0479 & Lagoa Nova & Charcoal? & $\begin{array}{l}\text { Early and mid- } \\
\text { Holocene? }\end{array}$ & Yes & \\
\hline E & SE Brazil & 1962 & Ciama 2 & Grasses, Pinus & 160 & Yes & Yes \\
\hline E & SE Brazil & 0487 & Lago do Pires & Deforestation, Z. mays, charcoal (since early and mid-Holocene) & 140 & Yes & \\
\hline E & SE Brazil & 0579 & Saõ Francisco de Assis & Charcoal (begin Holocene), Z. mays (1.9 kyr) & 10000 & Yes & \\
\hline $\mathrm{F}$ & Pampas & 2998 & Hinojales-San Leoncio & Exotic tree species (Eucalyptus, Pinus) & 100 & Yes & \\
\hline $\mathrm{F}$ & Pampas & 2423 & Lake Lonkoy & Exotic tree species (Eucalyptus, Pinus) & 100 & Yes & \\
\hline $\mathrm{F}$ & Pampas & 0216 & Laguna Sauce Grance & No & & & \\
\hline G & S Andes and Patagonia & 0745 & Onamonte & No & & Yes & \\
\hline G & S Andes and Patagonia & 0050 & Puerto Harberton & No & & Yes & \\
\hline G & S Andes and Patagonia & 0242 & Valle de Andorra & No & & & \\
\hline G & S Andes and Patagonia & 1990 & Cabo Vírgenes & Rumex presence & 50 & Yes & \\
\hline G & S Andes and Patagonia & 2996 & Cabo Vírgenes CV22 & Rumex presence & 50 & Yes & \\
\hline G & S Andes and Patagonia & 0083 & Laguna Azul & Rumex presence & 50 & Yes & \\
\hline G & S Andes and Patagonia & 0792 & Río Rubens & Rumex presence & 300 & Yes & \\
\hline G & S Andes and Patagonia & 0102 & Laguna Potrok Aike & Chenopodiaceae increase, Rumex presence & 150 & Yes & \\
\hline G & S Andes and Patagonia & 0734 & Lago Cipreses & Rumex presence, increase in shrub and herbs taxa & 60 & Yes & \\
\hline G & S Andes and Patagonia & 0050 & Lago Guanaco & Rumex, increase in Poaceae and Plantago & 60 & Yes & \\
\hline G & S Andes and Patagonia & 0025 & Cerro Frías & Nothofagus decrease, Rumex presence & 155 & Yes & \\
\hline G & S Andes and Patagonia & 3000 & Peninsula Avellanedo Bajo & Exotic species presence (Ast. Asteroideae, Rumex) & 25 & Yes & \\
\hline G & S Andes and Patagonia & 2484 & Parque Nacional Perito Moreno & No & & & Yes \\
\hline G & S Andes and Patagonia & 0657 & Mallín Pollux & Increase in Poaceae, Pinus and Plantago & 100 & Yes & \\
\hline G & S Andes and Patagonia & 1964 & Mallín El Embudo & Increase in Poaceae & 100 & Yes & \\
\hline G & S Andes and Patagonia & 1965 & Lago Shaman & Asteraceae sub Asteroidea & 250 & Yes & \\
\hline G & S Andes and Patagonia & 0099 & Lago Mosquito & Nothofagus decrease, Rumex and Pinus presence & 200 & Yes & \\
\hline G & S Andes and Patagonia & 2501 & Lago Lepué & No & & Yes & \\
\hline G & S Andes and Patagonia & 2321 & Lago Pichilafquen & Rumex, Pinus presence & 350 & Yes & Yes \\
\hline G & S Andes and Patagonia & 2320 & Lago San Pedro & Rumex, Pinus, Plantago presence, Poaceae increase & 121 & Yes & Yes \\
\hline G & S Andes and Patagonia & 0661 & Laguna de Aculeo & Micoralgae, Chenopodiaceae increase & 100 & Yes & \\
\hline G & S Andes and Patagonia & 0749 & Palo Colorado & Decrease in swamp forest taxa, increase in Maytenus and Asteraceae & $<620$ & Yes & \\
\hline G & S Andes and Patagonia & 2996 & Abra del Infiernillo & No & & Yes & \\
\hline
\end{tabular}

\subsection{Climate-vegetation interaction in the Central Andes}

The C Andes includes the high-elevation plateau of the Altiplano, above $3000 \mathrm{~m}$ a.s.l, in S Peru, Bolivia, and $\mathrm{N}$ Chile (Fig. 6 Box C). The Altiplano is an area of internal drainage within the Andes, which contains multiple peaks over $5000 \mathrm{~m}$ a.s.l.. The vegetation of the Altiplano is characterized by different grassland types, collectively known as "puna" (Kuentz et al., 2007). Within the grassland matrix are patches of woodland dominated by trees of the genus Polylepis (Fjeldså and Kessler, 1996). To the east and west of the Altiplano are the steep flanks of the Andes.

In total, 57 pollen records covering the last $2 \mathrm{kyr}$ were identified from the Altiplano in Peru and Bolivia. Only four of the Altiplano records met all PAGES-2k criteria: (i) Cerro Llamoca, (ii) Marcacocha, (iii) Chicha-Soras, and (iv) Pacucha (Fig. 9a; Table 3). From the surrounding regions two additional records are also considered here because of their importance and fit to the PAGES-2k criteria: (i) Consuelo on the E Andean flank, at mid-elevation (1370 m a.s.l.), and (ii) Urpi Kocha on the Pacific coast at sea level (within the archaeological site of Pachacmac). Of the seven sites considered in this review only two records (Cerro Llamoca and Consuelo) show no human interference, while the others indicate human impact during different periods of time throughout the last $2 \mathrm{kyr}$.

Discerning a climate signal from the pollen records of the last $2 \mathrm{kyr}$ in the $\mathrm{C}$ Andes is a challenge due to the long legacy of human occupation and landscape modification (Bennett, 1946; Dillehay et al., 2005; Silverman, 2008). However, some idea of vegetation-climate relationships can be gained from modern pollen studies within the puna; for example, Kuentz et al. (2007) use the ratio of Poaceae: Asteraceae (Nevado Coropuna) and Schittek et al. (2015) focus on the abundance of Poaceae (Cerro Llamoca) as an indicator of moisture availability. In the other records, where there is no direct relationship between vegetation and climate discernible, some authors look at the relationship between the pollen records and other indicators, such as independent evidence of farming activity (e.g. oribatid mites) or an association with archaeological evidence of abandonment or occupation (Chepstow-Lusty, 2011), to disentangle climate- and human-induced vegetation change. 
Table 3. Continued.

\begin{tabular}{|c|c|c|c|c|c|c|}
\hline Fig. 6 & Region & LAPD ID & Site name & References & $\begin{array}{l}\text { Latitude } \\
\text { (decimal } \\
\text { degrees) }\end{array}$ & $\begin{array}{l}\text { Longitude } \\
\text { (decimal } \\
\text { degrees) }\end{array}$ \\
\hline $\mathrm{D}$ & Amazon & 0599 & Terra Indigena Aningal & Da Silva Menenses et al. (2013) & -3.45 & -61.3 \\
\hline $\mathrm{D}$ & Amazon & 1557 & Vargas & Bush et al. $(2007 \mathrm{a}, \mathrm{b})$ & -12.33 & -69.12 \\
\hline $\mathrm{D}$ & Amazon & 2993 & Laguna El Cerrito & Whitney et al. (2014) & -13.25 & -65.39 \\
\hline $\mathrm{D}$ & Amazon & 2994 & Laguna Frontera & Whitney et al. (2014) & -13.22 & -65.35 \\
\hline $\mathrm{D}$ & Amazon & 2995 & Laguna San José & Whitney et al. (2013) & -14.95 & -64.50 \\
\hline $\mathrm{D}$ & Amazon & 0339 & Laguna Chaplin & Mayle et al. (2000), Burbridge et al. (2004) & -14.48 & -61.06 \\
\hline $\mathrm{D}$ & Amazon & 0566 & Rio Curua & Behling and Da Costa (2000) & -1.74 & -51.46 \\
\hline $\mathrm{D}$ & Amazon & 0521 & Lake Tapera & Toledo and Bush (2007) & 0.13 & -51.08 \\
\hline $\mathrm{D}$ & Amazon & 0483 & Lago Crispim & Behling and Da Costa (2001) & -0.77 & -47.85 \\
\hline $\mathrm{D}$ & Amazon & 1166 & Maxus-1 & Weng et al. (2002) & -0.45 & -76.62 \\
\hline $\mathrm{E}$ & SE Brazil & 0582 & São José dos Ausentes & Jeske-Pieruschka et al. (2010) & -28.94 & -50.04 \\
\hline $\mathrm{E}$ & SE Brazil & 3005 & Morro Santana & Behling et al. (2007) & -30.08 & -51.10 \\
\hline $\mathrm{E}$ & SE Brazil & 1998 & Rincão das Cabritas & Jeske-Pieruschka and Behling (2012) & -29.48 & -50.57 \\
\hline $\mathrm{E}$ & SE Brazil & 0437 & Cambará do Sul & Behling et al. (2004) & -29.05 & -50.10 \\
\hline $\mathrm{E}$ & SE Brazil & 0591 & Serra dos Órgãos & Behling and Safford (2010) & -22.46 & -43.03 \\
\hline $\mathrm{E}$ & SE Brazil & 0479 & Lagoa Nova & Behling (2003) & -17.97 & -42.20 \\
\hline $\mathrm{E}$ & SE Brazil & 1962 & Ciama 2 & Jeske-Pieruschka et al. (2013) & -27.90 & -48.87 \\
\hline $\mathrm{E}$ & SE Brazil & 0487 & Lago do Pires & Behling (1995) & -17.95 & -42.22 \\
\hline $\mathrm{E}$ & SE Brazil & 0579 & Saõ Francisco de Assis & Behling et al. (2005) & -29.59 & -55.22 \\
\hline $\mathrm{F}$ & Pampas & 2998 & Hinojales-San Leoncio & Stutz et al. (2015) & -37.57 & -57.45 \\
\hline $\mathrm{F}$ & Pampas & 2423 & Lake Lonkoy & Stutz et al. $(2012,2015)$ & -37.20 & -57.42 \\
\hline $\mathrm{F}$ & Pampas & 0216 & Laguna Sauce Grance & Fontana (2005) & -38.95 & -61.37 \\
\hline G & S Andes and Patagonia & 0745 & Onamonte & Heusser (1993) & -54.90 & -68.95 \\
\hline G & S Andes and Patagonia & 0050 & Puerto Harberton & Markgraf and Huber (2007) & -54.88 & -67.17 \\
\hline G & S Andes and Patagonia & 0242 & Valle de Andorra & Mauquoy et al. (2004) & -54.75 & -68.30 \\
\hline G & S Andes and Patagonia & 1990 & Cabo Vírgenes & Mancini (2007) & -52.33 & -68.38 \\
\hline G & S Andes and Patagonia & 2996 & Cabo Vírgenes CV22 & Mancini and Graham (2014) & -52.33 & -68.40 \\
\hline G & $\mathrm{S}$ Andes and Patagonia & 0083 & Laguna Azul & Mayr et al. (2005) & -52.08 & -69.58 \\
\hline G & S Andes and Patagonia & 0792 & Río Rubens & Huber and Markgraf (2003) & -52.07 & -71.93 \\
\hline $\mathrm{G}$ & S Andes and Patagonia & 0102 & Laguna Potrok Aike & Wille et al. (2007), Schäbitz et al. (2013) & -51.97 & -70.38 \\
\hline G & S Andes and Patagonia & 0734 & Lago Cipreses & Moreno et al. (2014) & -51.29 & -72.85 \\
\hline $\mathrm{G}$ & $\mathrm{S}$ Andes and Patagonia & 0050 & Lago Guanaco & Moreno et al. (2009) & -51.05 & -73.38 \\
\hline $\mathrm{G}$ & S Andes and Patagonia & 0025 & Cerro Frías & Tonello et al. (2009), Mancini (2009) & -50.40 & -72.70 \\
\hline G & S Andes and Patagonia & 3000 & Peninsula Avellanedo Bajo & Echeverria et al. (2014) & -50.27 & -72.84 \\
\hline $\mathrm{G}$ & $\mathrm{S}$ Andes and Patagonia & 2484 & Parque Nacional Perito Moreno & Mancini et al. (2002) & -47.88 & -72.85 \\
\hline G & S Andes and Patagonia & 0657 & Mallín Pollux & Markgraf et al. (2007) & -45.69 & -71.84 \\
\hline $\mathrm{G}$ & S Andes and Patagonia & 1964 & Mallín El Embudo & de Porras et al. (2014) & -44.67 & -71.70 \\
\hline G & S Andes and Patagonia & 1965 & Lago Shaman & de Porras et al. (2012) & -44.45 & -71.09 \\
\hline G & S Andes and Patagonia & 0099 & Lago Mosquito & Whitlock et al. (2006) & -42.83 & -71.67 \\
\hline $\mathrm{G}$ & S Andes and Patagonia & 2501 & Lago Lepué & Pesce and Moreno (2014) & -42.80 & -73.33 \\
\hline $\mathrm{G}$ & S Andes and Patagonia & 2321 & Lago Pichilafquen & Jara and Moreno $(2012,2014)$ & -41.14 & -72.80 \\
\hline G & S Andes and Patagonia & 2320 & Lago San Pedro & Fletcher and Moreno (2012) & -38.53 & -71.32 \\
\hline $\mathrm{G}$ & S Andes and Patagonia & 0661 & Laguna de Aculeo & Villa-Martínez et al. (2004) & -33.83 & -70.90 \\
\hline G & S Andes and Patagonia & 0749 & Palo Colorado & Maldonado and Villagrán (2006) & -32.08 & -71.48 \\
\hline G & S Andes and Patagonia & 2996 & Abra del Infiernillo & Garralla (2003) & -26.75 & -66.75 \\
\hline
\end{tabular}

The two records considered here that are purported to have no local human impact (Cerro Llamoca and Consuelo) provide the best opportunity of obtaining a clear insight into past climatic change in the $\mathrm{C}$ Andes during the last $2 \mathrm{kyr}$. The record from Cerro Llamoca indicates a succession of dry and moist episodes (Fig. 9b). After $0.5 \mathrm{ka}$, sediments are composed of redeposited and eroded material, and consequently the interpretation of the latter half of the record is difficult. In contrast, little compositional change is evident in the Consuelo record, with the most significant variance during the last $2 \mathrm{kyr}$ being a rise in Cecropia sp. pollen after $1 \mathrm{ka}$. $\mathrm{Ce}$ cropia pollen is typically interpreted as an indicator of disturbance (Bush and Rivera, 2001), and therefore, in the absence of humans signal, the rise in Cecropia could be interpreted as an elevated level of natural disturbance. The switch to very dry conditions at Cerro Llamoca in the western Andean cordillera and the rise in Cecropia at Consuelo on the E Andean flank are broadly coincident $(\sim 0.85 \mathrm{ka})$; however, it is not possible to say if this pattern results from a common climatic mechanism.

Archaeological evidence from Chicha-Soras does not show any evidence of human occupation of the valley between $\sim 1.9$ and $\sim 1.4 \mathrm{ka}$. Between 1.4 and $1 \mathrm{ka}$ and between 1 and $0.65 \mathrm{ka}$, a high abundance of Chenopodiaceae or Amaranthaceae (Chen-Am) could be interpreted as either indicating arid conditions or expansion of quinoa crops (Ledru et al., 2013b). However, a drop in charcoal fragments (fire activity) coupled with the absence of archaeological evidence $(\sim 1.9-1.4 \mathrm{ka})$ suggests that people abandoned the val- 
(a)

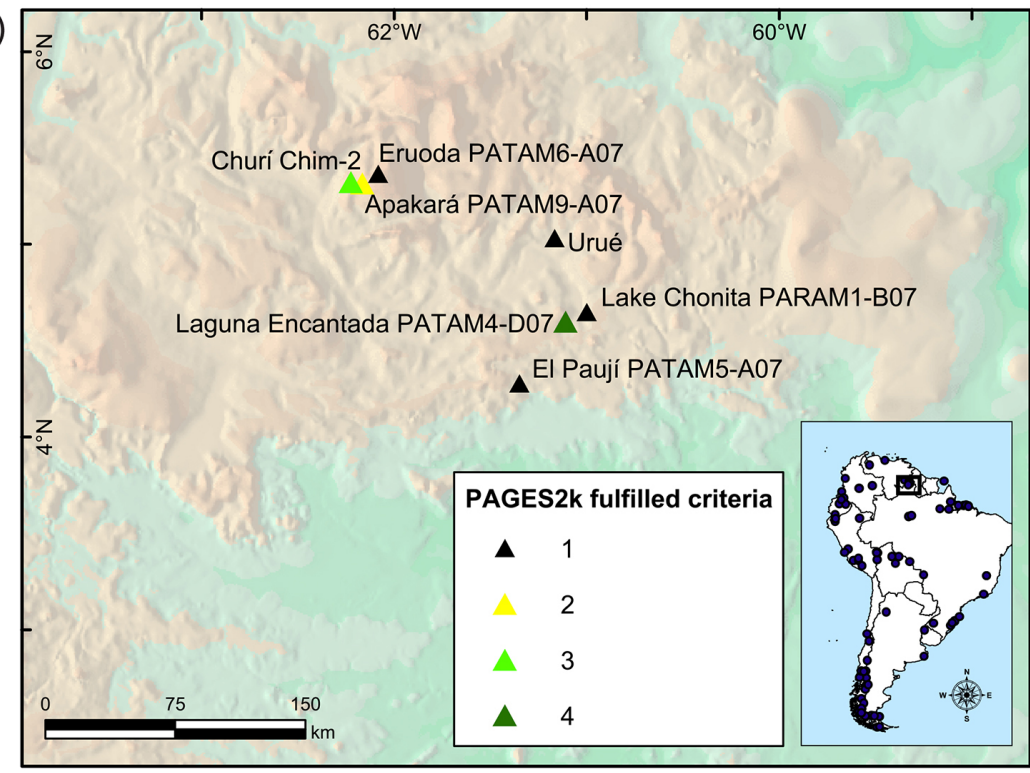

(b) Moisture balance summary $\quad$ Dry $\square \square \square$ Wet $\quad \square$ Humans present $\quad \square$ No record
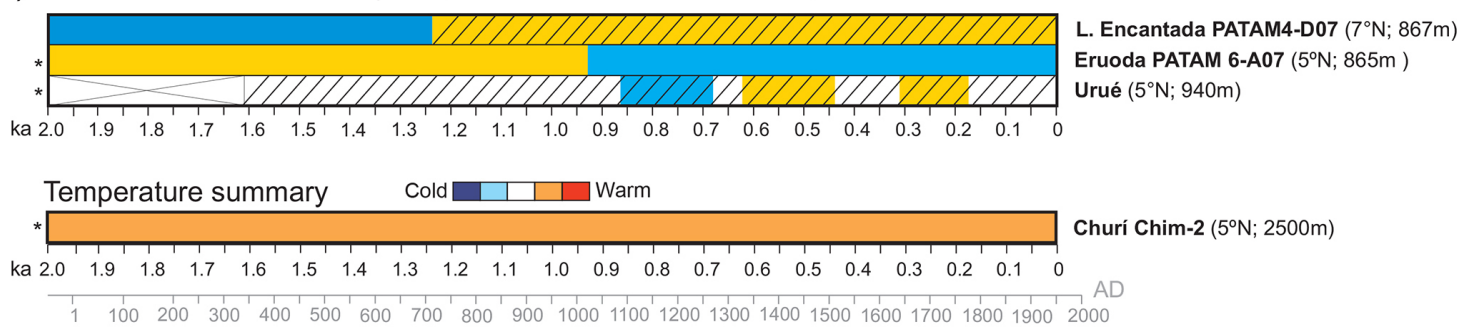

Figure 7. Panel (a): map showing the pollen records discussed in the Venezuelan Guayana highlands and uplands and the number of PAGES$2 \mathrm{k}$ criteria these records fulfill. Panel (b): summary of moisture balance and temperature including human interference for the pollen records discussed. Not all records are suitable to derive both a moisture and a temperature signal. Climate and human presence are shown overlapping when the pollen record is not conclusive regarding the derived signal. Records fulfilling one or two criteria indicated by star.

ley during $1.5-0.5 \mathrm{ka}$ and, consequently, that the aridity signal from the pollen could be interpreted as a climatic one.

Some climate information has been inferred from the four remaining sites (Marcacocha, Pacucha, Nevado Coropuna, and Urpi Kocha) despite the strong human influence on the vegetation. At Nevado Coropuna humid conditions persisted until a short dry episode occurred at 0.97-0.82 ka (Fig. 9b). During the last $2 \mathrm{kyr}$ at Marcacocha, successive peaks in Cyperaceae pollen have been interpreted as indicative of three periods of elevated aridity, while more abundant elevated Plantago at $\sim 1.9 \mathrm{ka}$ is suggested to indicate cooler conditions, and Alnus at $\sim 1-0.5 \mathrm{ka}$ could indicate warmer and drier conditions, although discerning the climate signal related to Alnus is difficult due to its utilization in agroforestry practices (Chepstow-Lusty and Jonsson, 2000). At Pacucha and Urpi Kocha, significant changes to the pollen assemblage in the last $2 \mathrm{kyr}$ are attributed to human activity rather than climate. Although the pollen records are likely to be somewhat obscured by the agricultural activities and irrigation of the crops, all high-elevation records with a moisture balance signal suggest generally drier conditions occurred in the $\mathrm{C}$ Andes between 1.2 and $0.7 \mathrm{ka}$ when compared with the rest of the last $2 \mathrm{kyr}$.

Generally, the pollen records from the Altiplano tend to show a greater sensitivity to precipitation rather than to temperature. The greater sensitivity to precipitation is because moisture availability is the limiting factor in most areas for both vegetation and human occupation. However, human occupation indicates changes in temperature: (i) at Marcacocha, when the sudden stop in agricultural activities is attributed to colder temperatures and (ii) at Nevado Coropuna, when the increase in human occupation (expansion of Inca culture) at higher elevation shows that there was no glacier but there were warmer temperatures.

\subsection{Climate-vegetation interaction in the lowland Amazon basin}

For the purpose of this review, the lowland Amazon basin constitutes those regions of the Amazon drainage below 

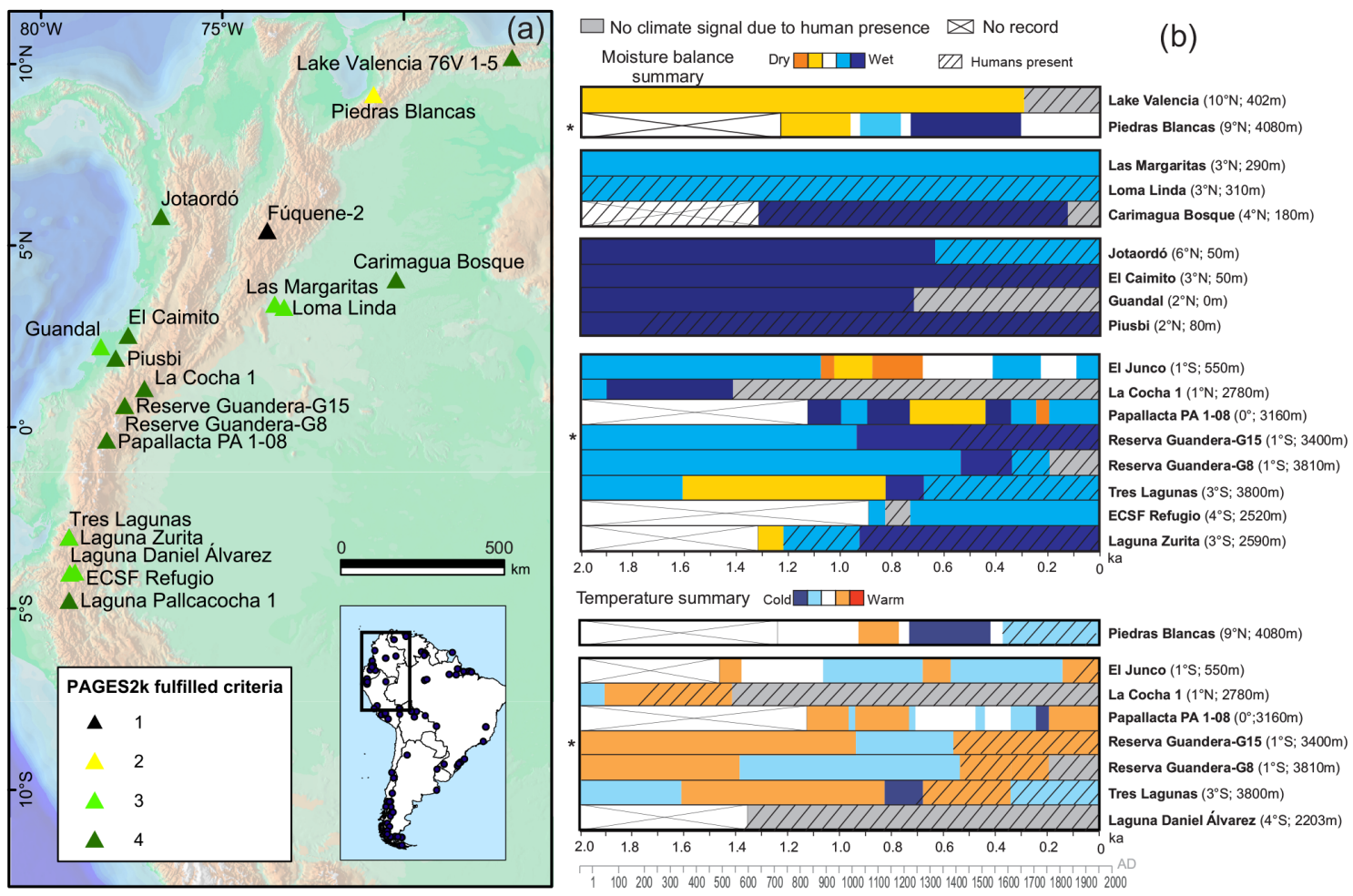

Figure 8. Panel (a): map showing the pollen records discussed in the Northern Andes and the number of PAGES-2k criteria these records fulfill. Panel (b): summary of moisture balance and temperature including human interference for the pollen records discussed. Not all records are suitable to derive both a moisture and a temperature signal. Climate and human presence are shown overlapping when the pollen record is not conclusive regarding the derived signal. Bars are shaded grey when the climate signal is obscured by human interference. Records fulfilling one or two criteria indicated by star. Galápagos Islands not shown.

500 m a.s.l. and extends to the lowland Guayanas (Fig. 6 Box D). This encompasses the evergreen rainforest, which covers most of Amazonia, as well as the southern transitional or seasonally dry tropical forests located in NE Bolivia and S Rondônia, N Mato Grosso, and N Para State, Brazil. It also includes the Llanos de Moxos savannas of NE Bolivia, and the ecotonal rainforest-savanna areas of N Roraima State, Brazil, and extends to the coastal swamps or grasslands of $\mathrm{N}$ Brazil and French Guiana.

In total, 42 published pollen records that cover the last 2 kyr were identified from the lowland Amazon basin. By applying the dating constraints of the PAGES-2k criteria, the majority of pollen records from the Amazon basin are discounted from any analysis of climate-vegetation interaction for the past $2 \mathrm{kyr}$. Only 5 records complied with all four of the criteria and 11 records met with three criteria (Fig. 10a; Table 3). One of these records, Lake La Gaiba, is situated just outside the Amazon basin, in the Pantanal region of central Brazil and SE Bolivia. However, the record and its hydrological catchment reflect Holocene precipitation in the S Amazon basin (Whitney et al., 2011), and it therefore was included as part of this review.

Lake Quistococha in the NE Peruvian Amazon is surrounded by a Mauritia flexuosa-dominated palm swamp.
Vegetation has undergone several significant species compositional changes over the past $2 \mathrm{kyr}$. The broad pattern of vegetation change was from Cecropia-dominated riverine forest at $\sim 2.2 \mathrm{ka}$ to abundant Cyperaceae and floating grasses or ferns and the commencement of peat formation $\sim 2.1 \mathrm{ka}$ to seasonally inundated riverine forest with abundant Moraceae and Myrtaceae from $\sim 1.9 \mathrm{ka}$ and, finally, the development of closed-canopy, Mauritia-dominated swamp from $\sim 1 \mathrm{ka}$ until the present. Superimposed on this broad pattern of change were rapid, centennial-scale shifts in forest composition and degree of openness. However, these rapid shifts were attributed by the authors to hydrological dynamics rather than to climate change or human impact.

Lake Werth belongs to a collection of sites (including Gentry, Vargas, and Parker) in the "Madre de Díos" region of the SE Peruvian Amazon. The lake formed at $\sim 3.4 \mathrm{ka}$ and records continuous evergreen rainforest throughout, with little evidence of burning. The records from the surrounding three lakes concur, suggesting that, regionally, rainforest (and climate) has been stable over the last $2 \mathrm{kyr}$.

Laguna Granja is located on the edge of the Pre-Cambrian Shield in NE Bolivia. The earliest date for the record is $6 \mathrm{ka}$ and indicates that savanna characterized the landscape from $6 \mathrm{ka}$. This is in agreement with a regional-scale reconstruc- 
(a)

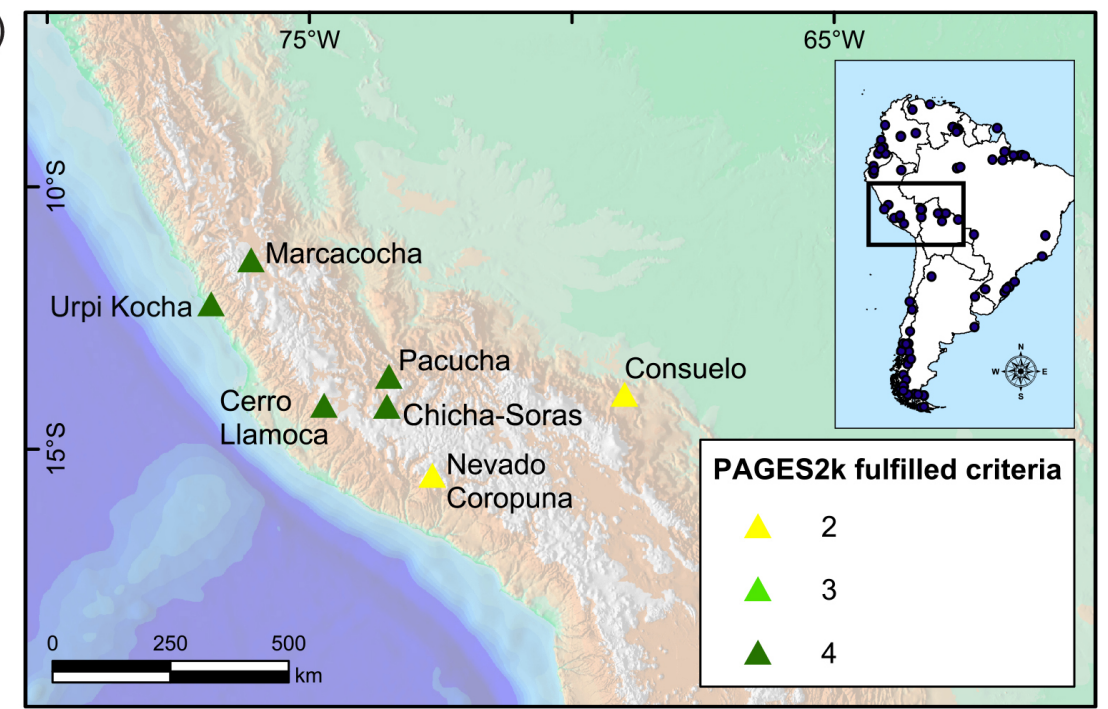

(b) Moisture balance summary Dry $\square$ No climate signal due to human presence

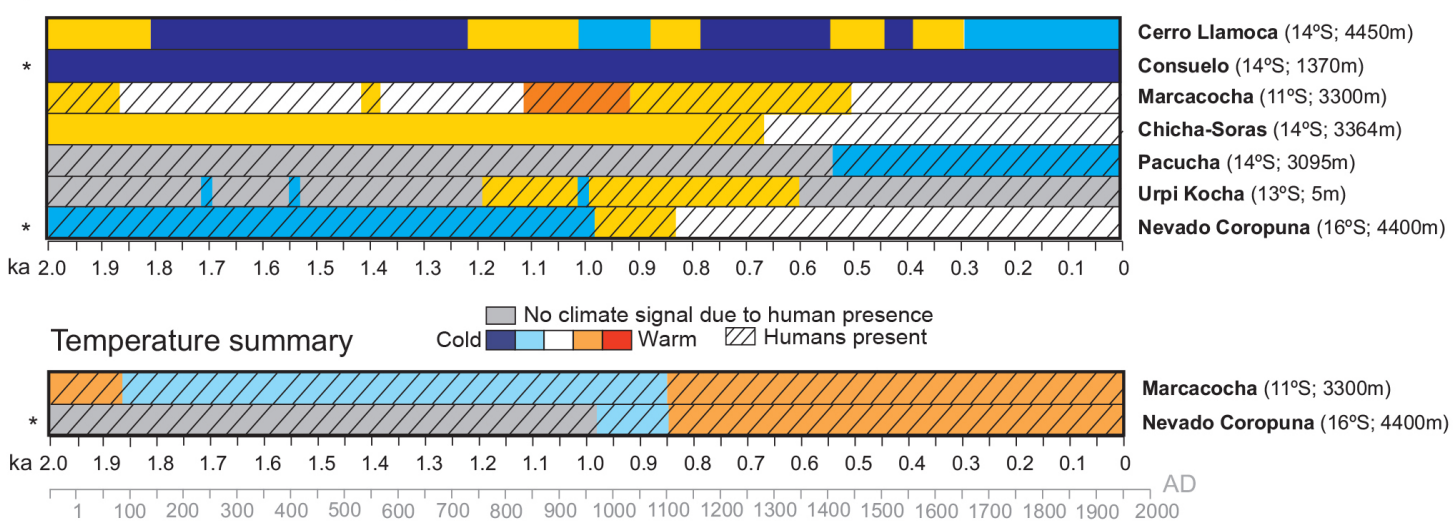

Figure 9. Panel (a): map showing the pollen records discussed in the Central Andes and the number of PAGES-2k criteria these records fulfill. Panel (b): summary of moisture balance and temperature including human interference for the pollen records discussed. Not all records are suitable to derive both a moisture and a temperature signal. Climate and human presence are shown overlapping when the pollen record is not conclusive regarding the derived signal. Bars are shaded grey when the climate signal is obscured by human interference. Records fulfilling one or two criteria indicated by star.

tion from the much larger Lake Orícore (not shown; Carson et al., 2014), which is located $<20 \mathrm{~km}$ away from Laguna Granja and shows climate-driven expansion of evergreen rainforest in this region between $\sim 2$ and $1.7 \mathrm{ka}$. However, forest expansion does not occur on the Granja site until $0.5 \mathrm{ka}$. The distribution of forest vs. savanna around Laguna Granja was shown to be heavily influenced by human land use between 2.5 and $0.5 \mathrm{ka}$ (Carson et al., 2014, 2015); therefore, it is not suitable for analysis of naturally driven vegetation dynamics.

The Fazenda Cigana record is in the savanna-galleryforest mosaic landscape in the $\mathrm{N}$ Brazilian Amazon. The core was taken as one of a pair, along with the Terra Indígena Aningal record, which was cored from the same Mauritia swamp. The pollen records are dominated by Mauri- tia throughout, attributed to continuously wet climate in this region in the late Holocene. There are however centennialscale periods of gallery forest reduction and grassland expansion, accompanied by increased charcoal concentrations. Da Silva Meneses et al. (2013) inferred that these periods of high burning were anthropogenic in origin and compared them to modern-day prescribed burning practices used by indigenous people in the northern Amazon to maintain an open savanna landscape. Despite the potential human interference, these records demonstrate natural stability of the forest-savanna ecotone over the last $1.5 \mathrm{kyr}$ in this particular part of the $\mathrm{N}$ Amazon.

The French Guiana K-VIII record was taken within a landscape of pre-Columbian mounded agricultural fields, with the principal aim of investigating ancient human land use 


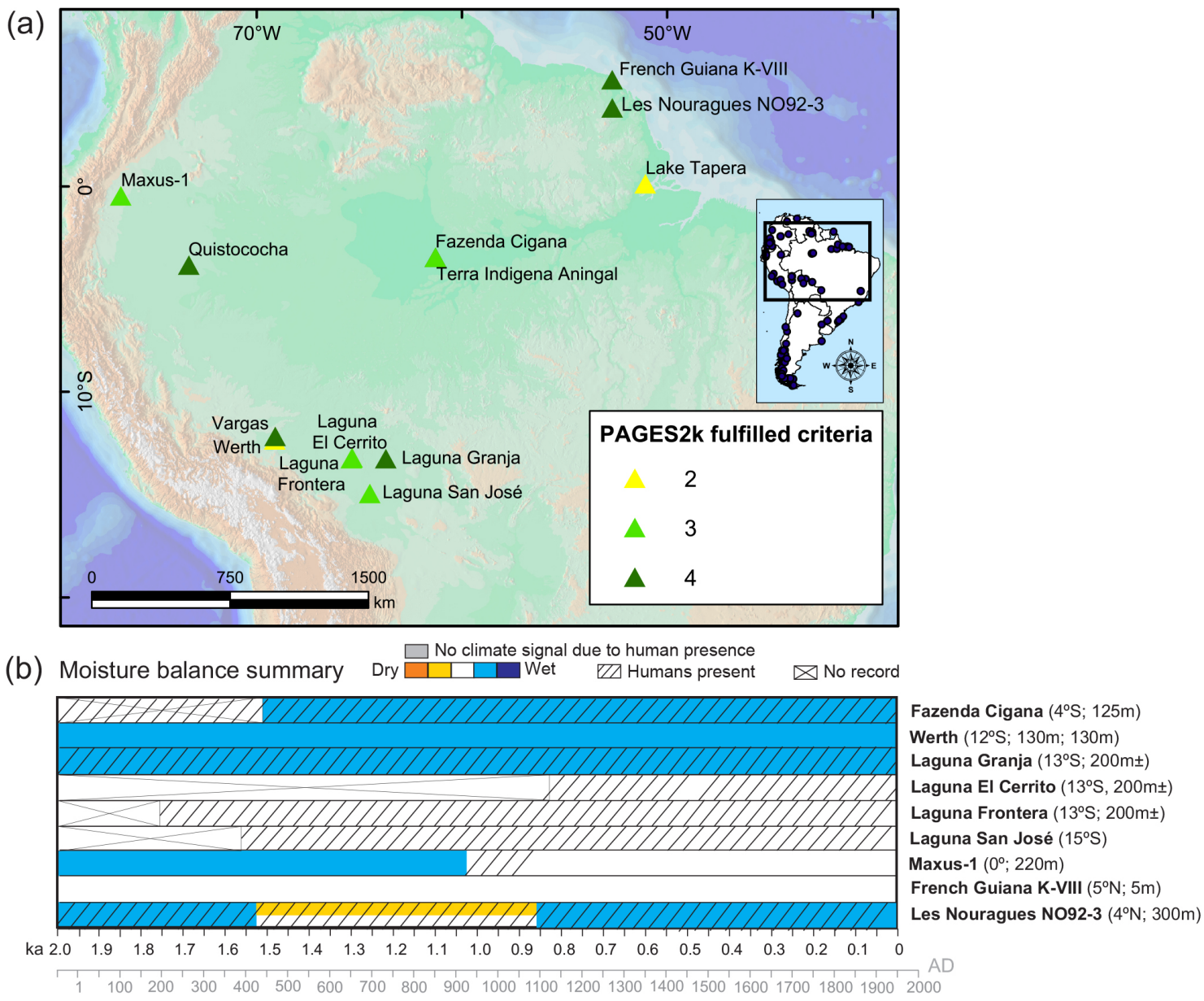

Figure 10. Panel (a): map showing the pollen records discussed in the lowland Amazon basin and the number of PAGES-2k criteria these records fulfill. Panel (b): summary of moisture balance and temperature including human interference for the pollen records discussed. Not all records are suitable to derive both a moisture and a temperature signal. Climate and human presence are shown overlapping when the pollen record is not conclusive regarding the derived signal. Records fulfilling one or two criteria indicated by star; $\mathrm{m} \pm$ : $\mathrm{m}$ a.s.l. based on coordinates.

associated with these earthworks on a local scale. From the earliest part of this record, the fossil pollen spectra indicate seasonally inundated savanna, dominated by Cyperaceae and Marantaceae until $0.8 \mathrm{ka}$, when human inference is detected. In the post-European period after $\sim 0.5 \mathrm{ka}$, charcoal abundance increases, probably reflecting more intensive use of fire by colonial populations.

\subsection{Climate-vegetation interaction in southern and southeastern Brazil}

The landscape in S and SE Brazil is diverse, from lowlands to high mountains, from subtropical regions with frost to tropical regions. Due to this heterogeneity distinct vegetation types occur throughout the region. The vegetation in S-SE Brazil includes forest ecosystems such as the tropical Atlantic rainforest, Araucaria forest, semi-deciduous forest, "Cerrado" (savanna woodland), and different grassland ecosystems such as "Campos" and "Campos de Altitude" (high-elevation grassland) (Fig. 6 Box E). There is a gradient from no or short dry seasons in the coastal lowland to 6-month dry seasons in the hinterland (northernmost part of the highland in SE Brazil), marking the vegetational gradient from moist Atlantic rainforest to semi-deciduous forest and to Cerrado. Additional background information is provided in the Supplement.

There are approximately 50 pollen records known from S-SE Brazil, but many sites have not been published in peerreviewed journals and were therefore not considered. Unfortunately, the two records that agree with all criteria show human interference (Table 3). Therefore, a general overview of climate-vegetation interaction from the region is presented, considering seven records that fulfil some of the criteria (Table 3, Fig. 11a).

In $\mathrm{S}$ Brazil pollen records indicate vegetational changes that reflect a change from a relatively dry climate during 
(a)

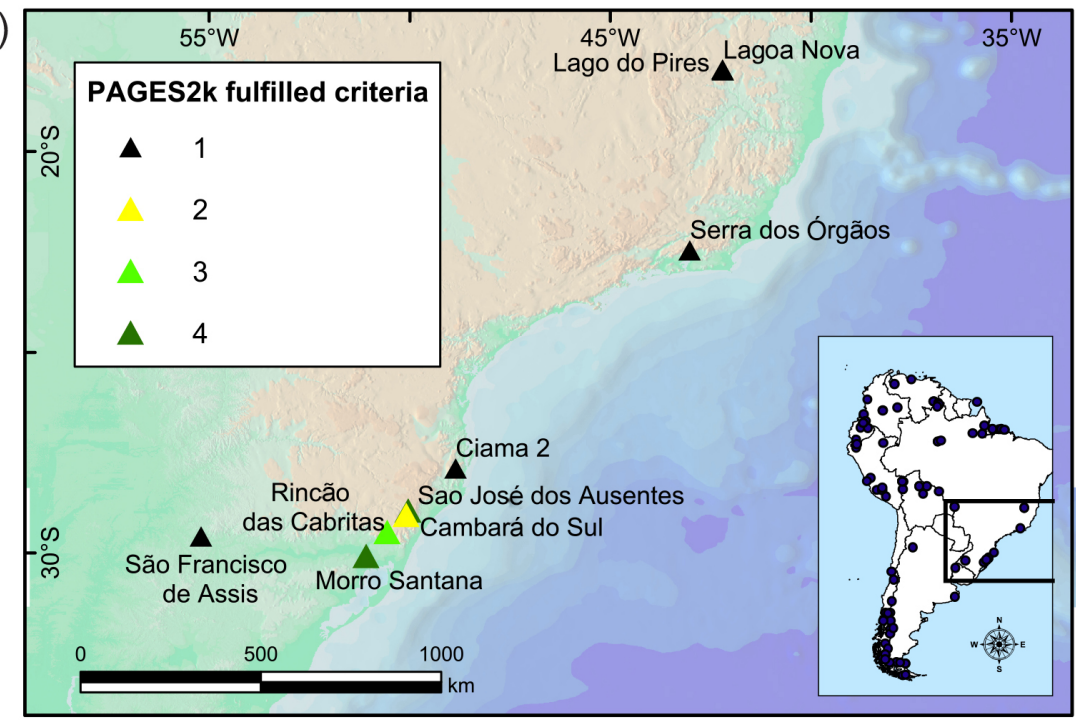

(b) Moisture balance summary Dry No climate signal due to human presence

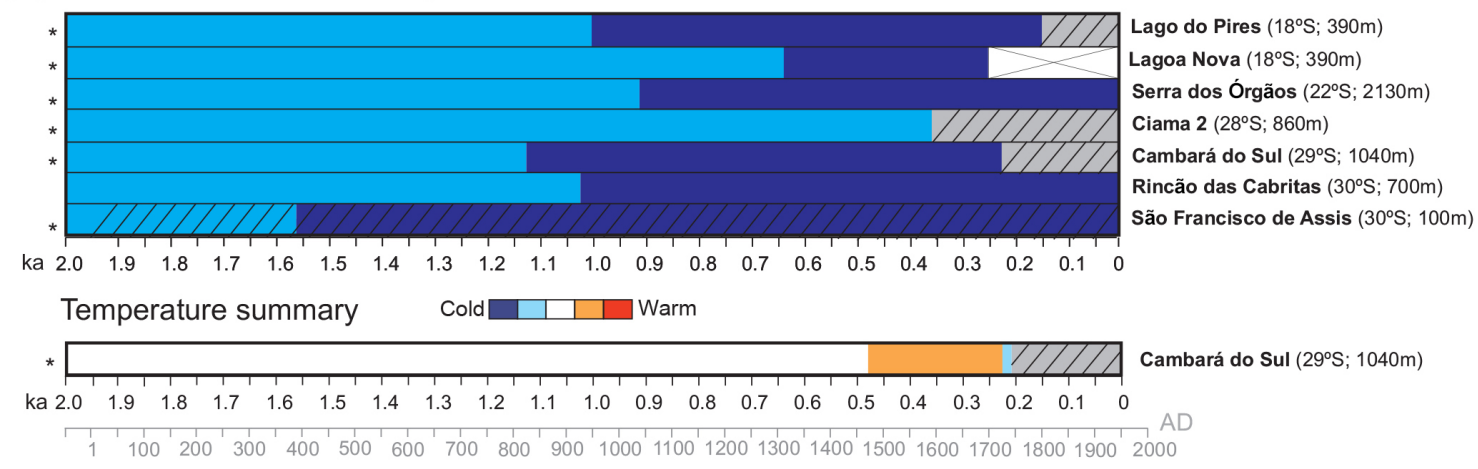

Figure 11. Panel (a): map showing the pollen records discussed in southern and southeastern Brazil and the number of PAGES-2k criteria these records fulfill. Panel (b): summary of moisture balance and temperature including human interference for the pollen records discussed. Not all records are suitable to derive both a moisture and a temperature signal. Climate and human presence are shown overlapping when the pollen record is not conclusive regarding the derived signal. Bars are shaded grey when the climate signal is obscured by human interference. Records fulfilling one or two criteria indicated by star.

the early and mid-Holocene to wetter conditions after about $4.3 \mathrm{ka}$, and in particular after $1.1 \mathrm{ka}$ (Fig. 11b). Increasing moisture is clearly indicated on the S Brazilian highlands by the expansion of Araucaria forests in the form of gallery forests along rivers and a pronounced expansion of Araucaria forest into the Campos after about $1.1 \mathrm{ka}$ (e.g. Cambará do Sul and Rincão das Cabritas). The expansion of gallery forests at similar time periods $(5.2$ and $1.6 \mathrm{ka}$ ) is also recorded in the southernmost lowland in S Brazil by the São Francisco de Assis record. Study sites that reflect changes in the Atlantic rainforest area indicate an expansion during the Holocene where overall wetter conditions prevailed compared to highland and southernmost lowland areas, e.g. Ciama 2 (Fig. 11b).

In contrast to other sites and regions, a relatively humid and warm phase during the LIA is inferred from the highresolution Cambará do Sul record as an expansion of Wein- mannia in the Araucaria forest is observed. In SE Brazil the Lago do Pires and Lagoa Nova record indicate that a dense and closed semi-deciduous forest existed in the region only during the late Holocene period under the current climatic conditions with $\mathrm{a} \sim 3$-month dry season. In the mountains of SE Brazil (e.g. Serra dos Órgãos record), a reduction in Campos de Altitude occurred at $0.9 \mathrm{ka}$, indicating a change to wetter conditions that is broadly coeval with a similar trend in the Lago do Pires record (Fig. 11b).

\subsection{Climate-vegetation interaction in the pampean plain}

The pampean plain extends east of the Andes, between 30 and $40^{\circ} \mathrm{S}$ (Fig. 6 Box F), and is characterized by aeolian landforms marking the climatic gradient of the landscape. The natural vegetation of the pampas is a treeless grassland, dominated by Poaceae in terms of both species number and 


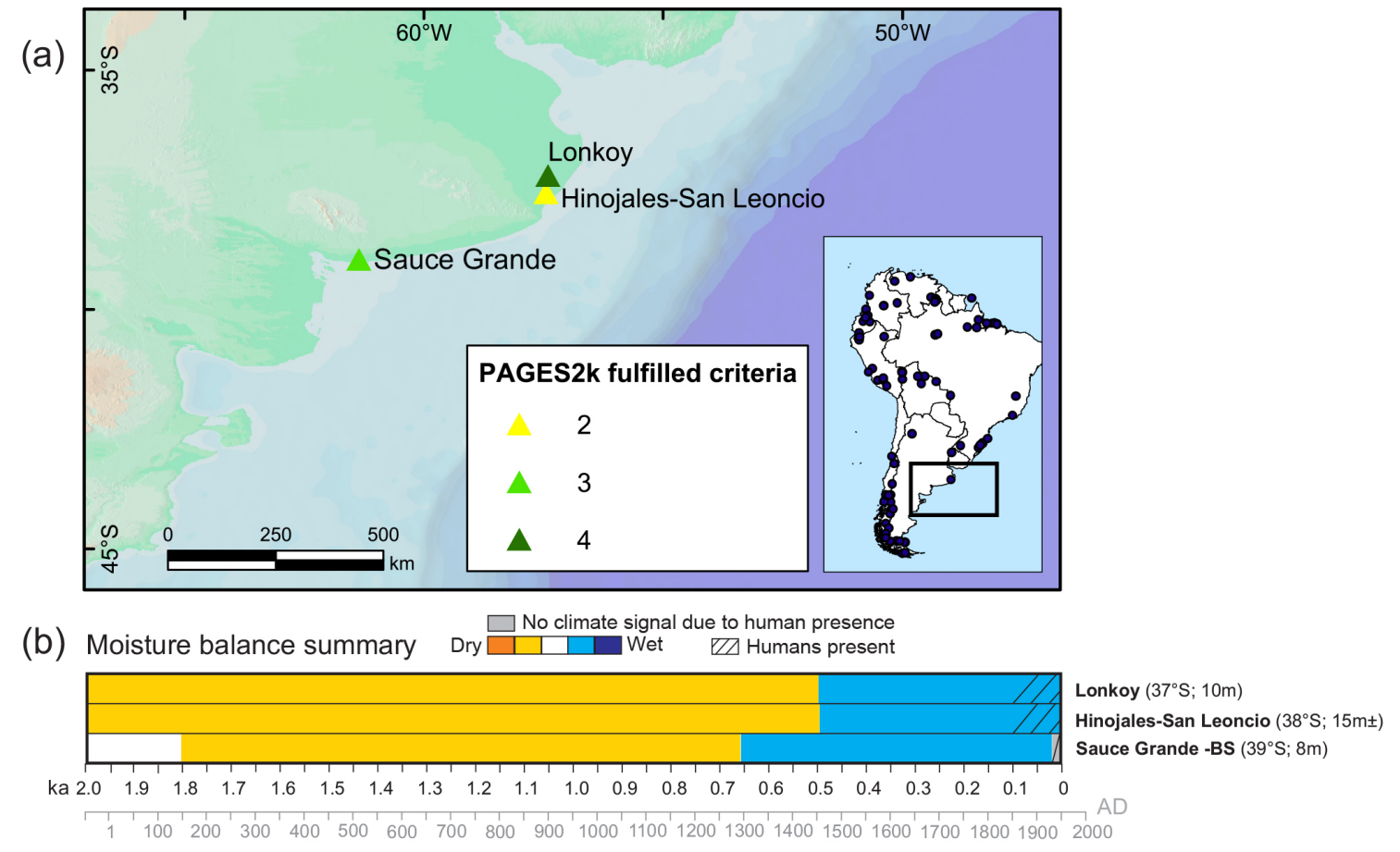

Figure 12. Panel (a): map showing the pollen records discussed in the pampean plain and the number of PAGES-2k criteria these records fulfill. Panel (b): summary of moisture balance and temperature including human interference for the pollen records discussed. Not all records are suitable to derive both a moisture and a temperature signal. Climate and human presence are shown overlapping when the pollen record is not conclusive regarding the derived signal. The section of the lower bar that is shaded grey indicates where the climate signal is obscured by human interference; $\mathrm{m} \pm$ : $\mathrm{m}$ a.s.l. based on coordinates.

abundance. Asteraceae shrubs (e.g. Baccharis and Eupatorium) are present locally in the $\mathrm{S}$ pampas, Cyperaceae characterize aquatic and wet-ground communities of temporarily flooded depressions and shallow lakes mainly from the E pampas, and Chenopodiaceae characterize edaphic communities such as salt marshes and alkaline flat areas (Tonello and Prieto, 2008). Additional background information is provided in the Supplement. In total, nine pollen records were assessed for the last $2 \mathrm{kyr}$ (Fig. 12a). All four dating criteria were met in one record only (Lake Lonkoy), and three criteria were matched at Sauce Grande (Table 3). The pollen record of the Hinojales-San Leoncio site does not fulfil the four dating criteria; however, the record shows important hydrological signals for the last $2 \mathrm{kyr}$ and is therefore briefly discussed.

Aquatic ecosystems are considered sensitive to climatic and/or hydrological variations and exhibit frequent fluctuations in their water level and extension, leaving flooded and/or exposed plains. Pollen together with non-pollen palynomorphs and plant macrofossil analysis present similar trends in the SE pampas that support the idea that climate is a regional trigger of change (Stutz et al., 2015). From 2 to $0.7-0.4 \mathrm{ka}$, an unstable regional environment with drier climatic conditions than at present is inferred for the region (Fig. 12b), based on halophyte plant communities (Chenopo- diaceae) surrounding the lakes, whereas Chara and other aquatic plants (e.g. Myriophyllum, Potamogeton) characterized the water bodies. Towards $\sim 0.5 \mathrm{ka}$, vegetation changed to Cyperaceae dominance and aquatic plant composition similar to modern associations. Thus, turbid conditions with a higher water level and/or an extension of surface lakes under more stable environmental conditions are inferred. These support humid conditions similar to the present with a noticeable increase in precipitation after $0.4 \mathrm{ka}$, indicated by high Cyperaceae abundances. However, an integrative multiproxy approach allows inferring stable conditions and higher salinity values between 1.9 and $0.9 \mathrm{ka}$ and periods of water level fluctuations after $0.9 \mathrm{ka}$, with high water levels between 0.66 and $0.27 \mathrm{ka}$. These changes may have been caused by fluctuations in precipitation (Fontana, 2005).

\subsection{Climate-vegetation interaction in the Southern Andes and Patagonia}

The study area comprises the S Andes, which includes subtropical and temperate regions $\left(22-56^{\circ} \mathrm{S}\right)$ on both sides of the Andes, including Patagonia $\left(40-56^{\circ} \mathrm{S}\right)$, which extends eastwards from the Andes to the Atlantic Ocean (Fig. 6 Box $\mathrm{G})$. The region has different geomorphological settings associated with glacial, volcanic, and tectonic activities. Vegetation associations reflect the west-east precipitation gradient 

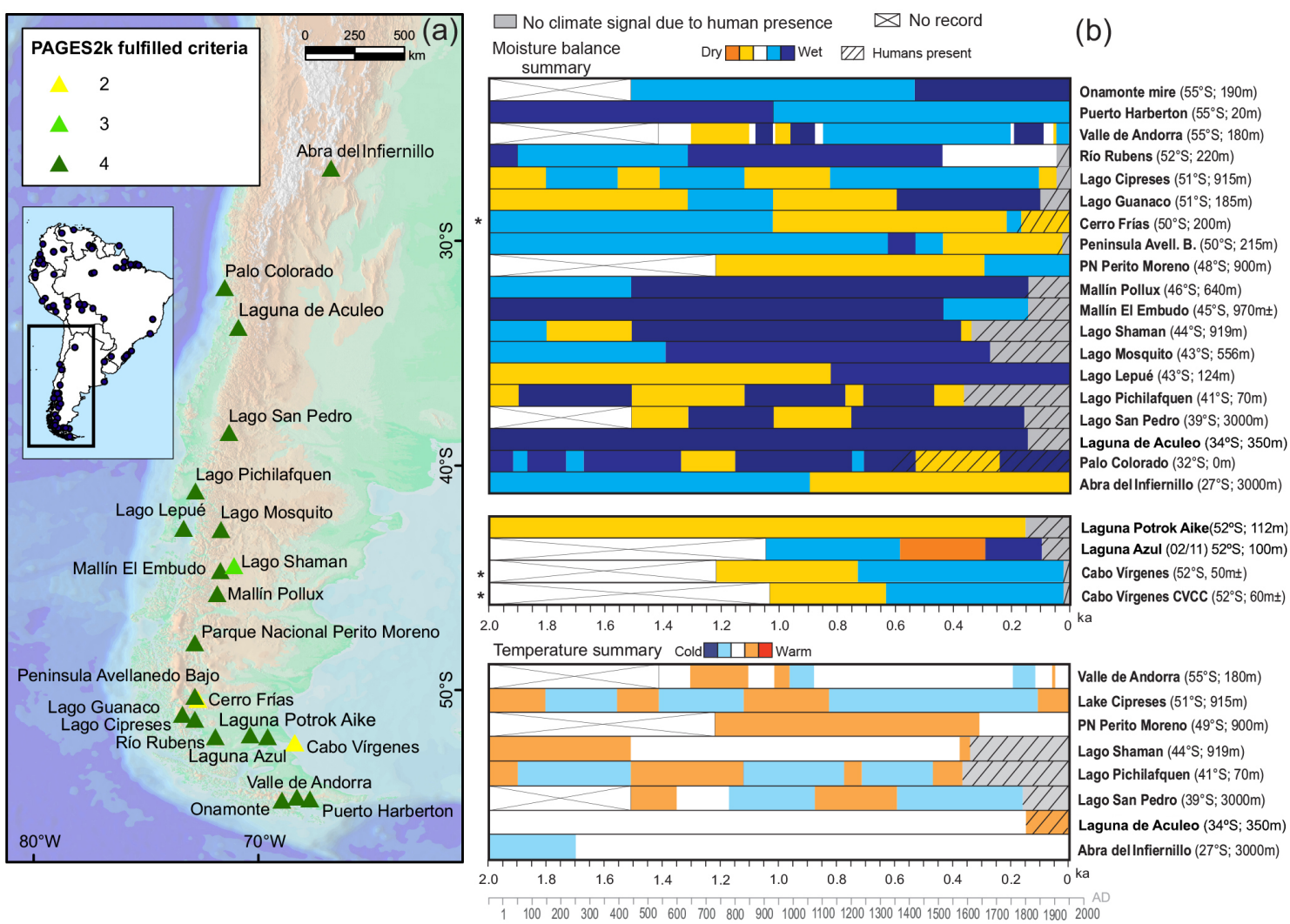

Figure 13. Panel (a): map showing the pollen records discussed in the Southern Andes and Patagonia and the number of PAGES-2k criteria these records fulfill. Panel (b): summary of moisture balance and temperature including human interference for the pollen records discussed. Not all records are suitable to derive both a moisture and a temperature signal. Climate and human presence are shown overlapping when the pollen record is not conclusive regarding the derived signal. Bars are shaded grey when the climate signal is obscured by human interference. Records fulfilling one or two criteria indicated by star; $\mathrm{m} \pm$ : $\mathrm{m}$ a.s.l. based on coordinates.

from the wet Nothofagus forest to the dry grass and shrub steppe towards the Atlantic coast. The south to north gradient along the Andes ranges from the Nothofagus temperate forest in the austral region to the Nothofagus-Austrocedrus forest, sclerophyllous forest, and xerophytic woodland in the central region. At the northernmost end of the latitudinal gradient, the vegetation is adapted to extremely arid conditions characterized by small and dwarf shrubs and scarce cover (see the Supplement for additional descriptions).

In this region, there are 48 pollen records that cover the last $2 \mathrm{kyr}$ with at least one chronological control point during this period. Of these, the 19 records that fulfil PAGES$2 \mathrm{k}$ criteria are mostly concentrated in the temperate forests, while only few originate from xerophytic shrub steppe (1 record), subtropical-sclerophyllous forest (2 records), and grass steppe (4 records) (Table 3; Fig. 13a).

There are three sites in the far south of Patagonia: the Tierra del Fuego's Onamonte mire $\left(54^{\circ} \mathrm{S}\right)$ located at the Nothofagus forest-grass-steppe ecotone shows a gradual Nothofagus forest development between 1.5 and $0.5 \mathrm{ka}$ followed by a major forest development up to the present, reflecting increased precipitation (Fig. 13b). Puerto Harberton $\left(55^{\circ} \mathrm{S}\right)$ in the mixed Nothofagus betuloides $-N$. pumilio forest shows Nothofagus dominance during the last $2 \mathrm{kyr}$, whereas the Ericaceae increase during the last $1 \mathrm{kyr}$ suggests a local decrease in the water table. Similarly, at Valle de Andorra $\left(54^{\circ} \mathrm{S}\right)$ in a Nothofagus pumilio forest, Empetrum-Ericaceae fluctuations reflect changing water tables.

In S Patagonia $\left(52-51^{\circ} \mathrm{S}\right)$ along the $\mathrm{E}$ Andes, there are several sites at or near the forest-steppe ecotone. Of these ecotonal sites, Río Rubens $\left(52^{\circ} \mathrm{S}\right)$ shows a closed Nothofagus forest until $0.4 \mathrm{ka}$ when European impact starts (Fig. 13b). Similarly, Lago Cipreses $\left(51^{\circ} \mathrm{S}\right)$ and Lago Guanaco $\left(51^{\circ} \mathrm{S}\right)$ show dominance of Nothofagus forest but with an increase in non-arboreal pollen (and a decrease in Nothofagus) associated with a reduction in precipitation induced by the southern westerly wind belt (SWWB) and the SAM phases. Furthermore, changes associated with dry or warm climate conditions appear to synchronize with northern hemispheric events, such as the Industrial Revolution, MCA, Roman Warm Period and Late Bronze Age Warm Period (Moreno et al., 2014), that alternate with wet and cool phases. Cerro Frías $\left(50^{\circ} \mathrm{S}\right)$ shows open forest from 2.0 to $0.9 \mathrm{ka}$, followed by a period in which grass steppe that is punctuated 
by an increase in Nothofagus at $0.016 \mathrm{ka}$ is prevalent. Estimates of annual precipitation suggest similar or higher values than in the modern period between 2 and $1 \mathrm{ka}$ and lower values between 0.9 and $0.015 \mathrm{ka}$, followed by similar-to-modern precipitation in the last $0.015 \mathrm{ka}$. Currently located in mixed deciduous Nothofagus forest, the Peninsula Avellaneda Bajo $\left(50^{\circ} \mathrm{S}\right)$ records an open forest from $2 \mathrm{ka}$, of which large expanses were replaced by grass steppe between 0.4 and $0.2 \mathrm{ka}$, associated with a decline in precipitation.

In C Patagonia $\left(47-44^{\circ} \mathrm{S}\right)$ pollen records are located in the east of Andes (Fig. 13a). At Parque Nacional Perito Moreno $\left(47^{\circ} \mathrm{S}\right)$, a shrub-steppe expansion (Asteraceae and Embothrium dominance) suggests lower precipitation values between 1.2 and $0.25 \mathrm{ka}$ compared to previous values, after which an increase in grass steppe occurs due to higher moisture availability (Fig. 13b). However, the Mallín Pollux $\left(45^{\circ} \mathrm{S}\right)$ record indicates an open canopy prior to $1.5 \mathrm{ka}$ followed by a Nothofagus forest expansion associated with a precipitation increase. Mallín El Embudo $\left(44^{\circ} \mathrm{S}\right)$, in a Nothofagus deciduous forest, shows unvarying forest composition during the last $2 \mathrm{kyr}$. Located in the same valley, the Lago Shaman $\left(44^{\circ} \mathrm{S}\right)$ record (Nothofagus forest-steppe ecotone) shows a more diverse pattern throughout the last $2 \mathrm{kyr}$, with a forest retraction at $\sim 1.7 \mathrm{ka}$ followed by an expansion around $1.5-1.3 \mathrm{ka}$ and a major forest development around $0.5 \mathrm{ka}$. The forest decrease during the last $0.2 \mathrm{kyr}$ is associated with human intervention.

In $\mathrm{N}$ Patagonia $\left(44-38^{\circ} \mathrm{S}\right)$, Lago Mosquito $\left(42^{\circ} \mathrm{S}\right)$ is the only record in the E Andes, and it is located at the transition between Austrocedrus woodland and shrubland steppe. The record shows an open Nothofagus-Austrocedrus forest with steppe and grassland elements between 2 and $1.4 \mathrm{ka}$, changing to higher Nothofagus forest dominance, which is attributed to wetter conditions (Fig. 13b). From $0.225 \mathrm{ka}$ to the present, Nothofagus shows a sharp decrease and Cupressaceae increases, together with a rise in introduced species, e.g. Rumex and Pinus. At the same latitude, Lago Lepué $\left(42^{\circ} \mathrm{S}\right)$, located on the Isla Grande de Chiloé and surrounded by evergreen rain forest, shows dominance of Nothofagus during the last $6 \mathrm{kyr}$ with an important reversal between 2 and $0.8 \mathrm{ka}$. This suggests lower precipitation than before and after $0.8 \mathrm{ka}$, shown by an increase in Weinmannia and Isoetes. The Lago Pichilafquen $\left(41^{\circ} \mathrm{S}\right)$ record, under the domain of the SWWB and influenced by the subtropical Pacific anticyclone in summer, shows a series of warm and dry and cold and wet phases for the last $2 \mathrm{kyr}$ (Fig. 13b). These phases are inferred by the varying abundances of Nothofagus and Eucryphia or Caldcluvia and Poaceae. The last centuries are characterized by human intervention. At the temperate-subtropical transition, the Lago San Pedro $\left(38^{\circ} \mathrm{S}\right)$ record shows drywarm phases, which were associated with the MCA period. Cold and wet conditions, inferred by the relation between Nothofagus and Poaceae and changes in the depositional time, prevailed during the LIA, possibly related to El Niño and La Niña influencing these wet and dry phases, respectively (Fig. 5).

To the north (west of the Andes), the Laguna de Aculeo record $\left(34^{\circ} \mathrm{S}\right)$ shows dominance of Poaceae, suggesting relatively steady conditions during the last $2 \mathrm{kyr}$, with the exception of the last $0.1 \mathrm{kyr}$, when a trend towards warmer conditions or human disturbance is reflected by an increase in Chenopodiaceae (Fig. 13b). Interestingly, the sedimentary record shows a series of turbidite layers associated with major ENSO frequency between 1.8 and 1.3 and between 0.7 and $0.3 \mathrm{ka}$ (Jenny et al., 2002). The Palo Colorado ( $\left.32^{\circ} \mathrm{S}\right)$ record shows dominance of Myrtaceae associated with wet conditions during the last $2 \mathrm{kyr}$ alternating with several dry pulses. A major dry peak at 0.4 ka may be related to climate and/or human activity. Similarly in the E Andes, Abra del Infiernillo $\left(26^{\circ} \mathrm{S}\right)$ shows an increase in moisture between 2 and $0.75 \mathrm{ka}$ inferred from Juncaceae, Poaceae, Cyperaceae pollen, and fern spores and a change to dry climatic conditions similar to modern conditions from $0.75 \mathrm{ka}$ on.

Laguna Potrok Aike and Laguna Azul (both $52^{\circ} \mathrm{S}$ ) show a dominance of Poaceae from $2 \mathrm{ka}$ onwards, with pollen of Nothofagus that was transported over a long distance. At Laguna Potrok Aike, reconstructed annual precipitation based on a transfer function indicates rising values during the last 2 kyr (Fig. 13b). Cabo Vírgenes $\left(52^{\circ} \mathrm{S}\right)$, located in the SE Patagonian grass steppe, shows a shrubland community between 1.2 and $0.7 \mathrm{ka}$, associated with drier conditions than at present. An increase in moisture after $\sim 0.7 \mathrm{ka}$ is indicated by Poaceae and Juncaginaceae pollen. Cabo Vírgenes CV22 shows a similar trend, with dry grass-shrub steppe between 1.05 and $0.6 \mathrm{ka}$, followed by a grass-dominated steppe suggesting higher moisture availability.

\subsection{Indicators of human land use in $2 \mathrm{kyr}$ pollen records}

In any past environmental change reconstruction concerning the last $2 \mathrm{kyr}$, human land use must be considered as a potentially important agent of environmental change. However, where there is no direct evidence of human land use, such as cultigen pollen, distinguishing natural from anthropogenically induced burning and vegetation change can be difficult. In some cases anthropogenic deforestation and decreased moisture may result in similar signals in the pollen record, and therefore complementary proxies of past environmental change can be used to support interpretations, such as chironomids (Matthews-Bird et al., 2015; Williams et al., 2012) and geochemical records from speleothems.

There are six key aspects of fossil records (pollen and charcoal) that can be seen as indicators of past human activity. These are (i) a decrease in forest taxa (degraded forest) and/or forest composition, (ii) the presence of crops, e.g. Zea mays, Manihot esculenta, and Phaseolus and Ipomoea, (iii) the presence of crop-related herbs, e.g. Rumex, (iv) an increase in grasses or herbs, e.g. Poaceae, Cyperaceae, and Asteraceae subf. Cichorioideae, (v) an increase in dis- 
turbance indicators, e.g. Chen-Am, Cecropia, Vismia, ferns, and palms (including Mauritia and Euterpe or Geonoma), and (vi) an elevated amount of charcoal due to anthropogenic fire (Fig. 14). These indicators of human activity can be split into two classes: those that directly indicate human presence and those from which it is indirectly inferred. Manihot esculenta and other crops, such as Zea mays, are considered direct indicators of human influence and provide clear evidence of land use. Indirect indicators, such as a change in forest composition (e.g. due to deforestation) or the appearance of species known as possible disturbance indicators (e.g. $\mathrm{Ce}$ cropia or Mauritia), need further evidence from other proxies to support any inference of past human activity. Only by looking at changes in pollen spectra in the context of other evidence (e.g. from charcoal, limnological, sedimentological, or archaeological data sets) can the most probable driver of any change be suggested.

In this paper, ambiguous records with few proxies were not immediately discarded but were considered within the context of the other records from their wider region. Based on this, an assessment could be made as to whether an anthropogenic signal may have obscured the natural vegetation change trajectory. The moisture balance and temperature summaries for each region (Figs. 7-13) clearly indicates when human interference obscures the climate assessment and when both climate and/or humans may have influenced the pollen record.

To date, major human impact in the Venezuelan Guayana uplands has been suggested for the last $2 \mathrm{kyr}$ and inferred from the charcoal record, without any evidence from crops. Compared to the highlands (1500-3000 m a.s.1.), the situation in the uplands (500-1500 m a.s.1.) differs substantially as fire is the factor most responsible for vegetation change during the last $2 \mathrm{kyr}$. The Urué record shows the consequence of repeated burning for the vegetation, preventing the recovery of pre-existing forests and allowing the appearance of "helechal" (fern-dominated vegetation; Huber and Riina, 1997) and the establishment of the savanna. The occurrence of frequent fires during the last $2 \mathrm{kyr}$ is a common feature of most of the upland records analysed so far, regardless of the plant association present at each location. Synchronous with this increase in fire regime, the records that nowadays are characterized by Mauritia palm swamps, showed parallel a sudden appearance and establishment of Mauritia. Human activities have been proposed as the likely cause of this high abundance of fires and thereby of the consequences that appeared in the landscape. In this sense, the repeated use of fires would have promoted the reduction in forests and expansion of the savanna, favouring the establishment of Mauritia swamps after clearing. Two records are particularly relevant regarding the human influence on the Venezuelan Guayana uplands. The Lake Chonita sequence (Table 3) was one of the earliest Mauritia establishments, coeval with a significant increase in the fire regime during a likely local wet period around $2 \mathrm{ka}$. In the southernmost boundary of the Venezuelan

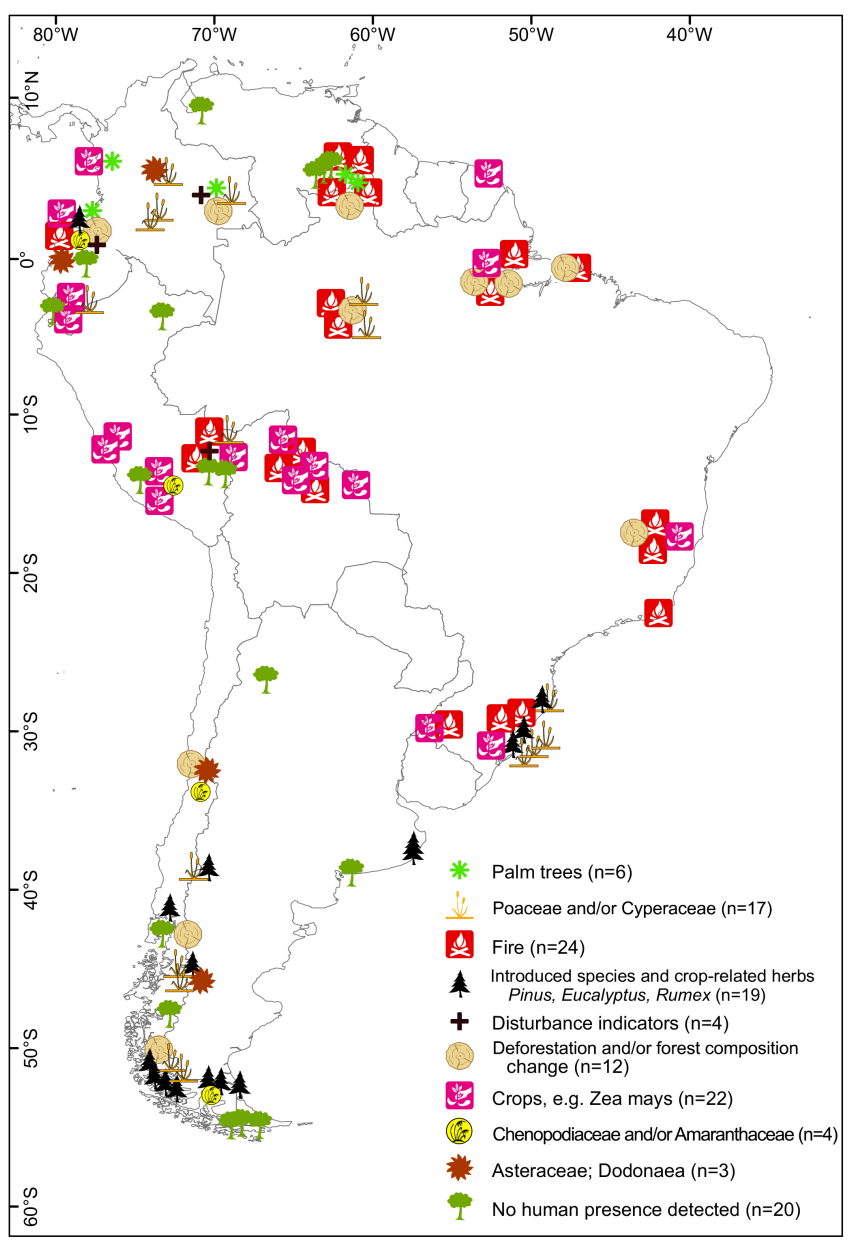

Figure 14. Map showing human indicators observed in the pollen records discussed $(n=68)$. The number of pollen records for each human indicator is shown in the figure legend. A pollen record can have different human indicators, and therefore the symbols may show an offset relative to their exact location to avoid overlapping point symbols. Details are found in Table 3.

Guayana, El Paují (Table 3) was interpreted as potentially reflecting human activities since the mid-Holocene. This location is characterized today by treeless savanna surrounded by dense rainforests that established themselves at $\sim 1.4 \mathrm{ka}$ as shown by the high abundance in the record of algal remains (local wet conditions) and charcoal particles (fire regime). The establishment of the present-day landscape was interpreted as mainly anthropogenically driven, with the arrival of the current inhabitants. The occurrence of a previous secondary dry forest was interpreted as the result of climatehuman interplay, linking land abandonment and likely drier climate as the main factor responsible for the vegetation shift. From the Colombian savannas, human occupation is attested since the mid-Holocene (Berrío et al., 2002). At site Loma Linda a plausible signal of human interference in the last $2 \mathrm{kyr}$ is the increased savanna, although precipitation increase during the same period (Behling and Hooghiemstra, 
1998, 1999; Marchant et al., 2001, 2002) could be interfering with that signal.

The human history in the $\mathrm{N}$ Andean region goes back to the Lateglacial period (Van der Hammen and Correal Urrego, 1978). The high plains of the Colombian Cordilleras have provided suitable conditions for human settlements since the start of the Holocene. Increasing human occupation became evident in pollen records after $\sim 3 \mathrm{ka}$, such as at Fúquene-2 and Pantano de Genagra. In several Andean pollen records, Rumex acetosella marked the arrival of Europeans from $0.4 \mathrm{ka}$ onwards (Bellwood, 2004; Bakker et al., 2008). Before these dates, indigenous populations were scarce and their practices negligible in terms of impact, especially at high-elevations sites such as Piedras Blancas in Venezuela.

In the tropical lowlands along the Pacific coast, increases in the presence of palms (mainly Euterpe or Geonoma) are commonly interpreted as a result of more intensive forest use, e.g. Lake Piusbi. Pollen grains from crops like Zea mays, Phaseolus, and Ipomoea are found in Piagua (Vélez et al., 2001). Human disturbance to the forest is considered indicated by high percentages of abundance of Cecropia, ferns, and palms. Decreases in human impact during the last $2 \mathrm{kyr}$ have been described by sites like Pitalito basin (Bakker, 1990; Wille et al, 2001), Timbio (Wille et al., 2000), Pantano de Genagra (Behling et al., 1998), Quilichao, and La Teta (Berrío et al. 2002), as grassy vegetation (Poaceae) and Zea mays disappeared and forest started to recover. This vegetation change could be related to the first arrival of the Spanish "conquistadores" (González-Carranza et al., 2012) or by a set of different causes (Wille and Hooghiemstra, 2000).

In the $\mathrm{C}$ Andes a high level of human activity, spatially variable in intensity, has been shaping the landscape for the last $2 \mathrm{kyr}$. Chen-Am and Zea mays generally appear in all the records in the Central Andes after 4 ka, e.g. Pacucha, Marcacocha, Chicha-Soras, and Urpi Kotcha. After $2 \mathrm{ka}$, Alnus and agroforestry practices are observed (Marcacocha, Pacucha). When irrigation started to be developed at sites without a nearby lake, as for instance $\sim 1 \mathrm{ka}$ at Nevado Coropuna, Ambrosia may have been used as a terrace consolidator. Evidence of afforestation at two sites with high human influence (Marcacocha and Pacucha) is observed. Indeed, Alnus acuminata is a tree planted by the Inca to stabilize landscapes (Chepstow-Lusty, 2011). At lower elevations, in the Andean forest, the last $2 \mathrm{kyr}$ pollen data indicate little change in woodland cover, which remains high on the E Andean flank (Consuelo) and low in the west (Urpi Kocha).

Of the 42 pollen records identified from the lowland Amazon basin, 15 show evidence of pre- and post-European land use within the last millennia. Human land use is inferred from these records from cultigen pollen grains, charcoal, and forest clearance (Table 3). In some cases there is also archaeological and archaeobotanical evidence for human land use. At many of the sites occupied by native Amazonians, evidence of decreased land use shows as a decline in burning by or before $0.5 \mathrm{ka}$, probably in relation to first European contact. However, some sites, such as French Guiana VII and Laguna Granja, show evidence of continued post-European land use.

In SE-S Brazil, the modern vegetation is strongly affected by the logging of forests and different agricultural land-use practices. During the last few decades, large-scale afforestation of grassland by Pinus is seen on the highlands. Similar to SE-S Brazil, the pampas region has a relatively short farming history, since most of the area remained native grassland until the end of the 19th and the beginning of the 20th century (Viglizzo and Frank, 2006). Today, only around $30 \%$ of the region is covered by natural or seminatural grassland. Pampas vegetation does not show evidence of human impact prior to European settlement at $0.4 \mathrm{ka}$. Europeans introduced several tree species (e.g. Eucalyptus, Pinus), as well as cattle (Bow taurus and Equus) and crops (Triticum aestivum, Helianthus annuиs), but the intensive agricultural activities only began $0.05 \mathrm{ka}$ (Ghersa and León, 2001). The palaeoenvironmental history of shallow lakes shows a change to more productive systems (higher mass of phytoplankton and organic matter content) during the last $0.1-0.08 \mathrm{kyr}$, probably due to agricultural activities. On the other hand, pollen records show an increase in pollen types associated with overgrazing (Plantago and/or Asteraceae Asteroideae) and exotic trees during the last $0.1 \mathrm{kyr}$.

In the S Andes and Patagonia, anthropogenic activities during the last century have caused a range of disturbances (e.g. fire, forest clearance, grazing, agriculture) and major vegetation changes in forest and steppe areas have occurred. There is no conclusive evidence of native human activities in the pollen records and native fire disturbance has been long discussed. Charcoal records from the E Andes flank have not revealed fire activity associated with native populations. A probable explanation for this lack of evidence is a low density of populations associated with a sporadic impact on forest (Iglesias and Whitlock, 2014). In general, human activities indicators are forest decrease, the presence of exotic pollen types (e.g. Rumex), and an increase of some pollen types (e.g. Asteraceae subf. Cichorioideae, Chenopodiaceae), associated with a European presence in the region. The time of colonization varied among S Andes and Patagonian sites, but $\sim 0.1 \mathrm{ka}$ can be considered as the start of European activities in Patagonia. Differences in timing of the first appearance of human indicators in pollen records could reflect European settlement dynamics, with an earlier presence at more northerly sites and later in more isolated areas (in the south of continent). The first human indicator is recorded at Río Rubens $\left(52^{\circ} \mathrm{S}\right)$ with the appearance of the European weed pollen Rumex acetosella in the early European era $(\sim 0.3 \mathrm{ka})$. 


\section{Discussion of the regional assessments}

\subsection{General observations for 2 ka pollen compilations}

This review reveals that those records with better dating resolution in the late Holocene are often from cores that span a shorter time period, while longer temporal records have less well-resolved Holocene chronologies. This likely reflects (i) the need to spread limited numbers of radiocarbon dates in order to provide robust age models for these deeper time records, (ii) the greater interest of previous researchers in potential large-scale palaeovegetation changes, driven by glacial-interglacial climate cycles, and other significant periods of climatic change, such as the early-to-mid Holocene drought, and (iii) the low sedimentation rate during the last millennia in certain regions, e.g. lowland Amazonia. Furthermore, strong anthropogenic interference during the last $2 \mathrm{kyr}$ complicates the interpretation of many records from a palaeoclimate perspective, but with expert knowledge, climate signals can be filtered. Additional difficulties arise from the "one topic focus" of many studies, and authors do not often present the full range of data in their publications that are required for a comprehensive reconstruction of vegetation, climate, and human impacts over the last $2 \mathrm{kyr}$.

\subsection{Venezuelan Guayana highlands and uplands}

For the Venezuelan Guayana region, we here discuss the highland and upland areas separately due to the significant differences in physiographical, climatic, and ecological features, as well as in the intensity of human pressure on their respective ecosystems.

The highlands are virtually pristine and, according to the palaeoecological records, they have remained in this state at least since the early Holocene. Therefore, climate has been the main driver of change. Palaeoecological records for the last $2 \mathrm{kyr}$ are scarce and generally of low resolution, but a common trait is the ecological stability as expressed in the vegetation constancy. The following hypotheses have been suggested to explain these observations: (i) environmental changes were insufficient to affect the highland vegetation, (ii) the high precipitation and relative humidity of the Chimantá summits (Briceño et al., 1990) have buffered climatic changes, and (iii) the study sites are unsuitable for recording significant vegetation changes because there are no vegetation ecotones nearby (Rull, 2015). Further work is needed to test these hypotheses. So far, palaeoecological fieldwork atop the tepuis has been carried out in an exploratory, nonsystematic manner due to the remoteness of the tepuis and the logistic and administrative constraints (Rull et al., 2008). In the LOTRED-SA framework, the issue of vegetation constancy emerges as a priority and should be addressed properly by finding suitable coring sites to be analysed with high-resolution multiproxy tools. The use of physical-chemical proxies independent of pollen and spores is essential to record climatic shifts. Lake sediments would be excellent for this purpose but, unfortunately, lakes are absent on tepui summits. The only permanent lake known so far is Lake Gladys atop the Roraima tepui, the age and origin of which remain unknown (Safont et al., 2014). At present, the analysis of the Apakará PATAM9-A07 core, which meets the PAGES-2k criteria, is in progress. The preliminary study of this core showed the main Holocene vegetation trends at millennial resolution (Rull et al., 2011), and the current analysis is being performed at multidecadal resolution. A new core obtained at the Uei summit (PATAM8-A07; not included in the Chimantá massif) and containing a decadal record for the last $2 \mathrm{kyr}$ is also currently being analysed (Safont, et al., 2016).

In the GS uplands, the situation is very different and the main driver of ecological change is fire caused by humans. This does not mean that climatic shifts have been absent or that they have not affected the vegetation, but the action of anthropogenic fires is more apparent than the action of climate and obscures it (Montoya and Rull, 2011). So far, regional palaeoclimatic trends, based on independent data obtained from the Cariaco basin $(\sim 680 \mathrm{~km}$ to the north; González et al., 2008), have been used as a reference for past climate change on the GS uplands (Rull et al., 2013). Unfortunately, a more local independent palaeoclimatic record for the GS uplands is still lacking, not only for the last $2 \mathrm{kyr}$ but also for the entire Holocene. Another limitation is that most palaeoecological records available for the GS uplands are from their southern sector, which is the lowermost part of the peneplains and has a different climate and vegetation regime as compared to the northern sector. Some records from the northern sector are available that fit with the chronological PAGES-2k requirements (Leal et al., 2011), but only summary diagrams are provided in peer-review publications and therefore they cannot be used in this reconstruction. The decadal to multidecadal analysis of a new core obtained in Kamoirán (PATAM10-A07), in the northern GS uplands, is in progress.

It should be stressed that the last $2 \mathrm{kyr}$ seem to have been critical for the ecological history of the GS uplands. Detailed knowledge of this period may be crucial to understand the origin of the present-day landscape, which is intimately linked to the temporal patterns of human impact from using fire. The date of arrival of the current indigenous culture (Pemón) at GS is still unknown. Based mainly on historical documents, it has been postulated that this culture settled in GS at $\sim 0.6$ to $0.3 \mathrm{ka}$, coming from Guayana or Brazil (Thomas, 1982, Colson, 1985; Huber, 1995a). However, these dates could be considered minimal ages, as recent palaeoecological studies suggest that human groups with landscape management practices similar to the Pemón people would have been present in the GS since $\sim 2 \mathrm{ka}$ (Montoya and Rull, 2011; Montoya et al., 2011a). Before that time, the GS landscape was different from the present, including larger extents of forested areas since the Lateglacial period 
(22-11.7 ka) and the absence of Mauritia palm swamps until $\sim 2 \mathrm{ka}$. The same time period seems to have been a landmark event in neotropical history for similar reasons, as Rull and Montoya (2014) showed a generalized increase in Mauritia pollen abundances in northern South America during the last 2 kyr.

Given the northern position of the Venezuelan Guayana, the vegetation responses studied have normally been related to ENSO and ITCZ movements. These two main drivers are represented by the Niño 3.4, AMO, IPO, and TNA modes, which do indeed exert the main influence in the area, as shown in Figs. 2-5 (especially with respect to temperature). The lack of a significant influence of AMO on precipitation in the region is surprising. It is worthwhile to compare the climatic inferences made through fossil pollen records with the climate modes' effect on the area. Fossil pollen records have suggested available moisture (or a precipitation/evapotranspiration ratio: $\mathrm{P} / \mathrm{E}$ ) as the main climatic driver to take into account for vegetation responses. However, these inferences are based on very local spatial scale proxies (e.g. algal remains). P / E is complex and higher temperature drives evapotranspiration, finally leading to lower water levels under unchanged precipitation regimes (Van Boxel et al., 2013). Interpretation of the fossil record is therefore complex and sometimes ambiguous. On the other hand, both Pacific and Atlantic climate modes appear to have a potentially large effect on both temperature and precipitation in the region. Such findings suggest that the variations in P / E inferred from the fossil record could be caused by either of these two factors, or by both. Additional higherresolution multi-proxy analyses should shed a light on previously undetected modes in the region as well as disentangle the combined effect of several forcing factors. Nevertheless, upland records have been interpreted as primarily humandriven vegetation responses, so for the last $2 \mathrm{kyr}$ the climatic conclusions are constrained. Highland records have been described as an example of constancy, even insensitive to temperature change during the last $2 \mathrm{kyr}$, which could confirm that the temperature variability related to climate modes in this region has been of a lesser magnitude than those required to cross the vegetation tolerance ranges. Alternatively the intrinsic characteristics of the sites studied so far have inhibited detecting any change.

\subsection{Northern Andes}

Study sites without human presence have been not identified with certainty within the northern Andean region, inhibiting the detection of a clear signal of climate tendencies in the last 2 kyr. Drier conditions prevailed in Colombian savanna lowlands, although the increased presence of Mauritia suggests either increased humidity and/or human influence. Along the Pacific coast, generally wetter conditions prevailed (Fig. 8b), but tectonic events might be masking clear patterns. The interpretation of some records should be undertaken with care due to the noisiness of the data. Furthermore, due to the geomorphological complexity of the landscape and its latitudinal characteristics, this region is prone to a combination of strongly overlapping climate signals within and between years (Figs. 2-5; Marchant et al., 2001).

For the Northern Andes the position of the ITCZ and the ENSO phenomenon are most important in driving changes in precipitation, as clearly illustrated in the La Cocha-1 record Figs. 4 and 5). Most significantly, the altitudinal gradient in temperature is modulated by ENSO and the TNA. This is shown by the increased temperature variability around $5 \mathrm{ka}$ when the ENSO signal starts (Figs. 2 and 3). The Papallacacta record highlights the two modes which affect precipitation variability in this region, namely the eastern equatorial Pacific and the tropical Atlantic. SST anomalies in both basins have been related to climate variability in the $\mathrm{N}$ Andes until $0.45 \mathrm{ka}$, with interdecadal variability dominating during the last $0.5 \mathrm{ka}$. Pallcacocha in $\mathrm{S}$ Ecuador also shows a close match with ENSO, recording its strength during the last $15 \mathrm{kyr}$. Similarly associated with ENSO are the changes in the plant assemblages detected in the high-resolution record of El Junco on the Galápagos Islands.

Comparing vegetation-climate signals between the Colombian lowlands and E Venezuela and NE Brazil has shown opposite climate conditions. Dry conditions identified in the Colombian savannas (suggesting an ENSO-La Niña) agree with similar conditions in the Bolivian pollen records. During an El Niño setting, when Bolivian savannas indicated wet conditions, the signal from Lake Valencia in Venezuela reflected dry conditions (Martin et al., 1997; Wille et al., 2003). Lowland sites generally show similar patterns of climate change during the last $2 \mathrm{kyr}$ and apparently synchronous events are observed over a larger spatial scale. This climate-sensitive transition zone is thought to reflect precession-forced changes in seasonality, latitudinal migration of the ITCZ, and changes in the ENSO (Figs. 3 and 4). The sites in the Andean region, on the other hand, are much more influenced by local geographical variability, causing a more variable response mechanism.

\subsection{Central Andes}

The records from the Central Andean Altiplano suggest an oscillation in moisture availability (precipitation) on a multicentennial timescale during the last $2 \mathrm{kyr}$ (Fig. 9b). These oscillations are probably due to differences in the strength of the summer precipitation. The timing of wet and dry events is not uniform between sites, probably due to local microclimates and differences in vegetation sensitivity to climate change, i.e. the high-elevation grassland (puna) versus midelevation Andean forest. The high-elevation peatland site of Cerro Llamoca is the only Altiplano site with no discernible local human impact and is the most robustly dated record used in this study, with 33 radiocarbon ages in the last 2000 years. The Cerro Llamoca record therefore likely represents 
the clearest palaeoclimate signal for the $\mathrm{C}$ Andean region. For example, records of glacial advance and retreat, and associated vegetation changes, from the Altiplano associated with the LIA are not discernible in any record, apart from Cerro Llamoca, because they are masked by changes associated with the arrival of Europeans, i.e. the abandonment of the sites and/or changes in agricultural practices.

The interpretation of the climate signal from the $\mathrm{C}$ Andes fossil pollen records suggests that during the last $2 \mathrm{kyr}$, precipitation, rather than temperature, was the key natural driver of vegetation change. Nonetheless, the increase in temperature observed at Nevado Coropuna during the Inca period, after $0.85 \mathrm{ka}$, could correspond to El Niño or IPO forcing. Furthermore, the decrease in temperature observed at Marcacocha between 1.85 and $0.85 \mathrm{ka}$ could be related to La Niña. The Pacific modes (Figs. 2 and 3) show a strong influence along the coast, which is in agreement with the results of the coastal pollen record (Urpi Kocha), where ENSO is considered responsible for extreme flooding events.

The greater sensitivity to precipitation seen in the pollen records is probably because moisture availability is the limiting factor for both vegetation and human settlement in most areas. On the Altiplano, variations in the SASM have been identified as a major driver of changes in moisture balance at Cerro Llamoca, Nevado Coropuna, and Pacucha through altering the summer precipitation. The SASM is also responsible for precipitation variations along the E Andean flank, as seen at Consuelo. As noted earlier, the highly seasonal precipitation in the $\mathrm{C}$ Andean region leads to rather weak correlations with ENSO and the IPO on an annual scale (Figs. 4 and 5). Notwithstanding this ENSO has been shown to have a significant influence in the $\mathrm{C}$ Andean region (both on temperature and precipitation) in numerous studies. It should also be noted that ENSO and IPO influence the intensity of the SASM (Garreaud et al., 2003; Vuille and Werner, 2005), thereby affecting moisture delivery to the Altiplano region, but because both ENSO and monsoon rainfall tend to peak during a fairly short period between November and February, this connection is not clearly expressed in Figs. 4 and 5.

\subsection{Lowland Amazon basin}

The lowland Amazon basin shows a high spatial complexity in relation to the various modelled climate modes (Figs. 25). ENSO and IPO, for example, both indicate strong negative relationships with precipitation in the northeastern quarter of Amazonia, where they induce drying over this region during their positive phase. Conversely, TSA shows a positive relationship with precipitation over the NE Amazon. Precipitation in the NE Amazon region is clearly strongly linked to tropical SSTs and ENSO variability. There are two pollen records in this region (Les Nouragues NO9203 and French Guiana VII), both of which display more local-scale forest dynamics with additional human interference. There- fore, these records are not considered suitable to investigate the effect of these modes on vegetation over the last millennia. New pollen-based reconstructions should be prioritized in this region to uncover the long-term drying effect of dominant ENSO-IPO or TSA modes on tropical lowland vegetation in the northeast. The most significant late Holocene vegetation changes are observed in records from the ecotonal areas of the S Amazon (lakes Chaplin, Bella Vista, Orícore, Carajás), where rainforest vegetation is located near the edge of its climatic range. Therefore, vegetation response to precipitation change is most likely to be observed. This rainforest expansion during the mid-to-late Holocene resulted from increasing insolation over the $\mathrm{S}$ tropics and the strengthening or migration of the SASM, a complex component of the climate system that is influenced by several dominant modes. Figures 4-5 show a weak negative precipitation anomaly across the lowland Amazon associated with the TNA mode. It is thought that higher sea surface temperatures in the tropical North Atlantic cause a reduction in Atlantic moisture reaching the Amazon during austral winter, thus extending the length or severity of the dry season, especially in $S$ and southwestern (SW) Amazonia (Lewis et al., 2011). The influence of the TNA mode may therefore be important to consider in Amazonian pollen records, given the known sensitivity of vegetation in these ecotonal areas to seasonal rainfall.

Most modes in Figs. 2-3 show high correlation and regression coefficients with temperature anomalies over the lowland Amazon. Temperature anomalies can play a role, but rainforest vegetation is unlikely to have shown sensitivity to temperature changes of $<1^{\circ} \mathrm{C}$ (Punyasena, 2008; Punyasena et al., 2008) but would show greater sensitivity to reductions in minimum annual temperature (i.e. frost).

Better-resolved late Holocene records originate from small lake basins (e.g. oxbows like Maxus-1, Laguna El Cerrito and Laguna Frontera), which have small pollen catchment areas. This means that they reflect predominantly local-scale changes and are, therefore, more susceptible to having their record of past environmental change dominated by signals of ancient human land use and local hydrology (e.g. savanna gallery forest) rather than regional climate. Many of these records from small basins were specifically selected in the original study to investigate local-scale human impacts around known occupation sites (Iriarte et al., 2012; Whitney et al., 2014; Carson et al., 2014, 2015). Examples of continuous anthropogenic signals during the last $2 \mathrm{kyr}$ are Laguna El Cerrito, Laguna Frontera, and Laguna San José (Fig. 10b).

In order to address these complicating factors of pollen catchment area and the anthropogenic signal, any future effort to obtain better-resolved Holocene pollen records in the lowland Amazon should carefully consider the sampling methodology employed. Carson et al. (2014) demonstrated that sampling a combination of small and large lake basins from within the same catchment allows a distinction to be made between local-scale, anthropogenic impact and regional-scale, climate-induced vegetation changes. In re- 
gions such as the $\mathrm{C}$ Amazon, where lakes are predominantly limited to small oxbows, a sampling approach might be to analyse cores from multiple records within the same locality and to compare those records in order to identify any regionally significant pattern of palaeovegetation change (Cohen et al., 2012; Whitney et al., 2014). Oxbow lakes build potentially dynamic archives and so require careful interpretation. However, their higher sedimentation rate means that they have the potential to provide high temporal-resolution palaeovegetation records of the late Holocene, which currently are largely absent from the Amazon lowlands.

Considering the large area of the Amazon basin, the number of pollen records is very small, and by applying the PAGES-2k criteria, those numbers are further reduced. Furthermore, the records which are excluded from the analysis by these criteria include some of the most important records of climate-driven vegetation change in the Amazon basin, e.g. lakes Orícore (Carson et al., 2014), Carajás (Hermanowski et al., 2012), and lakes Bella Vista and Chaplin (Mayle et al., 2000).

In order to avoid a "black hole" situation over the Amazon lowlands in any regional synthesis, one approach may be to apply a lower threshold of dating criteria. If the selection criteria are relaxed to allow for those records that are $>500$ years old and have at least two chronological control points within the last 2000 years, a further 14 records are added to the list of qualifying records. Also, if the criteria are stretched further to allow records with a lower date which is earlier than, but close to $2 \mathrm{ka}$, the Chaplin and Gentry records would also be included. Considering these records would provide coverage from the central Amazon River region, the $\mathrm{N}$ Brazilian Amazon, the E and NE coastal Amazon, and the southeastern and southwestern basin. However, even with these relaxed criteria, a number of key records would still be excluded, e.g. Pata (Bush et al., 2004; D’ Apolito et al., 2013), La Gaiba (Whitney et al., 2011), and Bella Vista (Mayle et al., 2000).

Any future investigation of late Holocene climatevegetation interaction may require new dating efforts to improve the age models of these key records. A Holoceneaged record from Lake La Gaiba produced by McGlue et al. (2012) has produced a better-resolved age model than the longer record from Whitney et al. (2011), which would meet the PAGES-2k criteria. However, McGlue et al. (2012) analysed the geochemical properties of sediments from a new core taken after the Whitney et al. (2011) study and did not include any pollen data. No attempt has been made subsequently to correlate the chronologies of the two records.

Although the dating resolution in the late Holocene is poor in many lowland Amazonian pollen records, it should be noted that the majority of pollen records also shows little variation in vegetation over the past $\sim 1$ or $2 \mathrm{kyr}$. Whether this reflects genuine ecosystem (and climate) stability over the late Holocene or is a product of low sampling resolution within these long records is unclear. Most of these deep temporal pollen records, as they are published now, likely have subsample intervals of insufficient resolution to be able to discern high-frequency events, such as vegetation changes associated with ENSO variability. However, in some cases, such as Bella Vista (Burbridge et al., 2004) and Orícore (Carson et al., 2014), the potential for such fine-resolution temporal reconstructions may be limited by the low sedimentation rate of the basins. Often these records come from short sediment cores, in which the Holocene time interval is contained within a short depth range (i.e. $<1 \mathrm{~m}$ ). A number of shorter records, spanning Holocene time periods, exist in the E coastal Amazon and could potentially provide high temporal-resolution reconstructions over the last $2 \mathrm{kyr}$. However, most do not currently meet the PAGES-2k dating criteria.

\subsection{Southern and southeastern Brazil}

The limited number of pollen records from S-SE Brazil for LOTRED-SA-2k has several reasons besides the insufficiently dated cores: (i) many archives, in particular peat bogs, have very low sedimentation rates, i.e. often $100 \mathrm{~cm}$ of peat deposit encompasses the complete Holocene (last $11.7 \mathrm{kyr}$ ), and (ii) the upper part of peat archives contains actively growing roots and is therefore difficult to date.

Despite the limited number of study sites available, general vegetation changes in S-SE Brazil can be established (Fig. 11). Pollen assemblage shifts suggest a change toward wetter conditions over the last $2 \mathrm{kyr}$, in particular due the reduction in the dry-season length. The increased moisture availability is generally thought to commence in SE Brazil between 6 and $4 \mathrm{ka}$ but is particularly pronounced in SSE Brazil during the last $\sim 1 \mathrm{kyr}$. Sites located in the highlands of S-SE Brazil along the transition zone between the subtropics and tropics are sensitive to both temperature and precipitation, but in the lower elevations, the length of the dry season plays a more important role than temperature. This dry-season length is modulated by the interplay between SASM and SACZ, which bring abundant rainfall to SE Brazil during the summer months (October-March) and the South Atlantic Anticyclone, a semipermanent high-pressure system located over the subtropical South Atlantic. The main impetus for rainfall on interannual timescales is ENSO, as El Niño events tend to bring copious rainfall to the region (Figs. 4 and 5).

According to the pollen records, the intra-annual variability plays an important role in SE and S Brazil. The generally long annual dry period during the early and mid-Holocene limited the expansion of different forest ecosystems, while a much shorter annual dry period during the late Holocene allowed a strong expansion of forests, in particular of the Araucaria forest in S Brazil. Interannual variability, influenced by the ENSO frequency, which increased during the late Holocene, may also have a certain effect on the vegetation in the region. El Niño events cause high rainfall rates in 
S-SE Brazil (Garreaud et al., 2009). This is consistent with results in Fig. 4, which show a positive correlation between precipitation in the region, on the one hand, and Nino3.4 and the IPO, and to a lesser extent also the TSA, on the other hand. The effect of the slightly increasing precipitation in $\mathrm{S}$ Brazil may be rather small, however, as rainfall is already relatively high, as inferred from the records of past environmental change from $\mathrm{S}$ Brazil.

According to Fig. 2, the correlation of annual mean temperature over SA with the climate modes Nino3.4, IPO, AMO, and TNA suggest a slight warming associated with the positive phase of these modes (Fig. 3). Increasing temperatures sustained over a long period may cause a slight shift of tropical plant populations to higher elevations on the mountains in SE Brazil and a slight expansion of tropical plants on the southern highlands.

\subsection{The pampean plain}

There are several pollen records in the pampean plain that span Holocene times, but few of them have well-resolved chronologies for the last 2 kyr. Just one site fulfills all PAGES-2k criteria. Previously, pollen analyses in the pampean plain region have been carried out on alluvial sequences, or archaeological sites, which usually contain sedimentological discontinuities that impede a good chronological control. These pollen records show regional vegetation changes and climate inferences related to precipitation changes (humid, dry, or arid conditions) or sea level fluctuations, mainly on a millennial or centennial scale. Until today, few studies have focused on elucidating palaeoenvironmental changes at a high temporal resolution during the last $2 \mathrm{kyr}$. Furthermore, the pampean plain has a high number of potential sites: shallow lakes characterized by a continuous sedimentation that would provide robust age models and highquality pollen records. Conversely, the current pollen records do not have the necessary resolution to identify vegetationhuman interaction during the last $0.3 \mathrm{kyr}$, and therefore improved chronological control and higher resolution is necessary.

General climatic tendencies in the region can be inferred although few accurately dated pollen records are available. While individual palaeoecological studies reveal local developments, general patterns emerge when information from several sites is combined, such as Lonkoy and HinojalesSan Leoncio (Fig. 12b). A multi-proxy approach, including pollen analyses, shows synchronous changes in these shallow lakes from the SE pampas that are mainly a response to precipitation variations. Thus, between 2 and $0.5 \mathrm{ka}$, drier conditions than at present are inferred. Then, a transition phase towards more humid conditions is observed, which stabilizes between $\sim 0.3$ and $0.1 \mathrm{ka}$, with values close to modern values (Stutz et al., 2014). These climatic inferences are valid for the southeastern region but do not extend to the entire pampean plain. In the $\mathrm{S}$ pampean plain, multi-proxy inter- pretation at Sauce Grande (Fontana, 2005) shows a similar change to more humid conditions at $0.66 \mathrm{ka}$ and similar conditions to the present day after $0.27 \mathrm{ka}$, but pollen composition shows a low responsiveness to change (Fig. 12a). New palaeoenvironmental reconstructions based on pollen records are needed to disentangle the intrinsic ecosystem variability from climate and to elucidate whether climatic events such as the MCA or LIA had different expressions in the pampean plain.

As seen in Figs. 2-5, these plains fall outside the areas that are strongly influenced by the investigated climate modes. Nonetheless, Figs. 2 and 3 indicate that the positive phase of the TSA (a warm tropical South Atlantic) leads to a cooling over the region, while a slight warming is associated with the positive phase of the IPO. In Fig. 5, a weak positive correlation between rainfall in the region and the Niño 3.4 and IPO modes is observed, which was previously also discussed by Barros et al. (2006). The SAM on the other hand is negatively correlated with precipitation in the region (Fig. 4), consistent with results by Silvestri and Vera (2003), although this relationship has not yet been explored in pollen records as a possible influence in the region. Hitherto, studies from the pampean plain have only discussed dry or humid conditions associated with reduced or increased precipitation, but no attempt to link these observations to large-scale climate variability has been made. The situation in this region is further complicated by the fact that the moisture supply to the region stems from two distinct sources, the South Atlantic (Labraga et al., 2002) during austral winter and the SA monsoon system (Vera et al., 2006) during the austral summer. Hence, pollen-based precipitation reconstructions also need to consider changes in the seasonality of precipitation and not just climate variability associated with external influences from ENSO or the SAM. Seasonally stratified analyses of the influence of ENSO or the SAM could therefore provide additional insights into the climate-vegetation interpretation as focusing on annual mean values may mask strong seasonal signals in the same way as discussed above for the C Andes.

\subsection{Southern Andes and Patagonia}

Even though a large number of pollen records are available in the $\mathrm{S}$ Andes and Patagonia region, just 19 (between 32 and $54^{\circ} \mathrm{S}$ ) fulfil the PAGES-2k criteria. In Patagonia most pollen studies have been carried out with a focus on vegetation and climate change over different or longer timescales, i.e. the Pleistocene-Holocene transition (ca. $11.7 \mathrm{ka}$ ) or the entire Holocene (last $11.7 \mathrm{kyr}$ ). The pollen records are considered to mainly reflect changes in the SWWB and hence to be indicative of the polarity of the SAM. Southern records receive precipitation related to the SWWB, whereas those located to the north $\left(40-32^{\circ} \mathrm{S}\right)$ are also influenced by the subtropical Pacific anticyclone (SPA) that blocks winter precipitation along a latitudinal gradient (decreasing precipitation during JJA in the southern part to scarce precipitation during DJF in 
Table 4. List of abbreviations.

\begin{tabular}{|c|c|}
\hline Abbreviations & \\
\hline ALLJ & Andean low-level jet \\
\hline AMO & Atlantic Multidecadal Oscillation \\
\hline $\mathrm{C}$ & Central \\
\hline Chen-Am & Chenopodiaceae or Amaranthaceae \\
\hline DJF & December-January-February \\
\hline $\mathrm{E}$ & East(ern) \\
\hline ENSO & El Niño-Southern Oscillation \\
\hline GS & Gran Sabana \\
\hline IPO & Interdecadal Pacific Oscillation \\
\hline ITCZ & Intertropical Convergence Zone \\
\hline JJA & June-July-August \\
\hline LAPD & Latin American Pollen Database \\
\hline LIA & Little Ice Age \\
\hline LOTRED-SA & LOng-Term multi-proxy climate REconstructions and Dynamics in South America \\
\hline m a.s.l. & Metres above sea level \\
\hline MCA & Medieval Climate Anomaly \\
\hline $\mathrm{N}$ & North(ern) \\
\hline $\mathrm{NE}$ & Northeast(ern) \\
\hline NW & Northwest(ern) \\
\hline PAGES & Past Global Changes \\
\hline $\mathrm{P} / \mathrm{E}$ & Precipitation / evapotranspiration ratio \\
\hline$S^{\prime}$ & South(ern) \\
\hline SA & South America \\
\hline SACZ & South Atlantic convergence zone \\
\hline SAM & Southern Annular Mode \\
\hline SASM & South American summer monsoon \\
\hline SE & Southeast(ern) \\
\hline SON & September-October-November \\
\hline SPA & Subtropical Pacific anticyclone \\
\hline SST & Sea surface temperature \\
\hline SW & Southwest(ern) \\
\hline SWWB & Southern westerly wind belt \\
\hline TNA & Tropical North Atlantic SST \\
\hline TSA & Tropical South Atlantic SST \\
\hline UFL & Upper forest line \\
\hline $\mathrm{W}$ & West(ern) \\
\hline
\end{tabular}

the northern part). Furthermore, the Andean ridge provides for a fundamental climatic divide with stronger westerlies leading to enhanced precipitation to the west of the divide, while sites located in Patagonia east of the Andean divide receive enhanced precipitation associated with winds from the east (Garreaud et al., 2013). In addition to this east-west asymmetry, the comparison between northern and southern records could also shed light on the expansion or retraction and/or latitudinal shifts of the SWWB or a differential influence of the SPA. For example, records south of $46^{\circ} \mathrm{S}$ show relatively dry conditions between $\sim 1$ and $0.5 \mathrm{ka}$, whereas drought occurs between 2 and $1.5 \mathrm{ka}$ at sites north of this latitude (Fig. 13b). Differences in seasonality are another key feature distinguishing precipitation records in $\mathrm{N}$ Patagonia (summer rainfall, e.g. Lago San Pedro) from records further north in central Chile (winter rainfall, e.g. Laguna de Aculeo and Palo Colorado). Due to the regional complexity of the climate, the region cannot easily be characterized by a single climate mode. Different patterns are distinguished (Fig. 13b), due to their geographical position, latitude, position east or west of the Andes, and the intrinsic sensitivity of each record to climatic variability.

Superimposed on the seasonally changing SWWB and SPA dynamics are the interannual influences of the SAM or Antarctic Oscillation and ENSO (Figs. 2-5). The positive phase of the latter (El Niño) is associated with humid winters in subtropical Chile and with dry summers in northwest (NW) Patagonia (Montecinos and Aceituno, 2003). Sites in $\mathrm{N}$ Patagonia and C Chile therefore might be suitable to study this asynchronous behaviour with regard to ENSO activity (e.g. Lago San Pedro and Laguna de Aculeo). 
The strongest influence in the region on interannual timescales, however, is exerted by the SAM. Figures 2-5 show a highly inverse correlation with precipitation and a positive correlation with temperature over the southern tip of South America (especially south of $40^{\circ} \mathrm{S}$ ). The strong influence of the SAM on Patagonian climate, with drier and warmer than average conditions associated with its positive phase, is well known and consistent with previous analyses by Gillet et al. (2006) and Garreaud et al. (2009). Southernmost Patagonia therefore appears as a key area to study climate-vegetation variability associated with the SAM (e.g. Lago Cipreces). LIA and MCA chronozones are well recorded both in S and N Patagonia (e.g. Lago Cipreses, Peninsula Avellaneda Bajo, Lago San Pedro) but not in central Chile.

\section{Conclusions}

Through this review and analysis, ca. 180 fossil pollen records that fulfill at least two of the PAGES-2k criteria for robust climate reconstruction were identified for SA. Although this is still a relatively small number, compared to the total number of fossil pollen records available from SA (ca. 1400; Flantua et al., 2015), we expect that the number of high-quality sites for reconstruction of climate over the last $2 \mathrm{kyr}$ is likely to increase rapidly as new work is produced. To conduct a review on this scale, it was necessary to divide SA into seven subregions. Firstly, we summarize the finding from each region and then draw broad conclusions regarding the patterns across the whole of SA.

\subsection{Conclusions by region}

The following are the findings for the Venezuelan Guayana highlands and uplands (seven study sites reviewed, Fig. 7):

- Moisture balance and temperature: records show a higher sensitivity to moisture than to temperature. Two drought intervals were detected coeval with the Little Ice Age (LIA) in the Venezuelan Andes. Wet conditions prevailed on the tepuian summits during the last $1 \mathrm{kyr}$.

- Humans: impact has been inferred from the charcoal record, without any evidence of crops (four of seven records). The use of fires can favour the reduction in forests and expansion of the savanna, favouring the establishment of Mauritia swamps after clearing. Earliest Mauritia establishment was observed around $2 \mathrm{ka}$, but humans might have been present since the midHolocene leaving their signature on the present-day landscape.

- Climate modes (Table 1): both Pacific and Atlantic climate modes (Niño 3.4, AMO, IPO, and TNA modes) are predicted to have a large effect on Venezuelan Guayana, especially with regard to temperature. However, the fossil pollen records from the highlands show no responses to temperature variability, suggesting that tolerance ranges were not surpassed and that temperature thus did not produce vegetation shifts. The precipitation / evapotranspiration ratio may play an additional important role not yet studied.

Findings from the Northern Andes region (21 study sites reviewed; Fig. 8):

- Moisture balance and temperature: fossil pollen records are both moisture balance and temperature sensitive, with tropical lowlands more sensitive to moisture and Andean areas more sensitive to temperature. Overall wetter conditions with warm and cold episodes are seen during the last $2 \mathrm{kyr}$. These shifting temperatures are displayed asynchronously in the records, and changes in ENSO frequency have been detected in multiple records.

- Humans: Andean records without human impact are rare (just 4 of the 21 records) and a wide range of indicators for human activity is found. These include deforestation (loss of tree taxa) and the appearance of introduced taxa, e.g. palms, crops, and disturbance taxa. The high level of evidence of humans in this region is not surprising given that the history of the human occupation of the Andes goes back to the Lateglacial period (ca. $10 \mathrm{ka}$; Van der Hammen and Correal Urrego, 1978).

- Climate modes: the altitudinal gradient in temperature is most importantly modulated by Pacific modes (Niño3.4) and the TNA. Records show a close match with precipitation variability trigged by ENSO that displays a highly diverse spatial pattern throughout the region (Fig. 4).

Findings from the Central Andes (seven study sites reviewed; Fig. 9):

- Moisture balance and temperature: fossil pollen records are more sensitive to changes in moisture balance than temperature. The records on the E Andean flank (Amazon flank) suggest overall moist conditions during the last 2 kyr, while the W Andean flank (valleys and Pacific flank) shows a succession of dry and moist episodes. Generally drier conductions occurred in the C Andes between 1.2 and $0.7 \mathrm{ka}$ when compared with the rest of the last $2 \mathrm{kyr}$.

- Humans: only two of the seven records reviewed were found not to contain any evidence of human activity. Human presence and land use provides hints on changes in temperature, i.e. suggesting that the climate became more favourable for human populations. However, arid conditions during $1.5-0.5 \mathrm{ka}$ may have forced humans to abandon the Andean valleys, as there is evidence of 
afforestation at two sites with high human influence. Human indicators are mostly the occurrence of crop pollen, e.g. Zea mays.

- Climate modes: Pacific modes show a strong influence along the coast in the C Andean region. The SASM is responsible for precipitation variations along the $\mathrm{E}$ Andean flank, leading to weak correlation of ENSO and the IPO on an annual scale. Nevertheless, ENSO and IPO influence the intensity of the SASM and have been shown to influence both temperature and precipitation significantly.

Findings from the lowland Amazon basin (19 study sites reviewed; Fig. 10):

- Moisture balance and temperature: fossil pollen records from the lowland Amazon basin are moisture sensitive and indicate continuously wet climate throughout the last $2 \mathrm{kyr}$; however, centennial-scale shifts are observed in terms of forest composition attributed to hydrological change.

- Humans: human activity has been detected in most records (15 of 19 sites), evidenced by fire (charcoal abundances), forest clearance, and crops, e.g. Zea mays and Manihot esculenta. After European contact, land use decreases as shown by a decline in burning around $0.5 \mathrm{ka}$.

- Climate modes: precipitation in the NE Amazon region is strongly linked to tropical sea surface temperatures and ENSO variability. ENSO and IPO induce drying in the NE Amazonia during their positive phase, while TSA induces precipitation. Both the Pacific and the Atlantic modes show high correlation and regression coefficients with temperature anomalies over the lowland Amazon.

Findings from southern and southeastern Brazil (seven study site reviewed; Fig. 11):

- Moisture balance and temperature: Records are moisture sensitive and indicate continuously wet climate throughout the last 2 kyr. Changes in forest composition suggest a relatively humid and warm phase during the LIA, in contrast to other regions.

- Humans: most human impact occurred during the last $0.4 \mathrm{kyr}$ as indicated by the increased use of fire. Furthermore, in the southern part of Brazil, human modification of ecosystems is indicated by the appearance of introduced taxa such as Pinus and Eucalyptus.

- Climate modes: Nino3.4, IPO, AMO, and TNA suggest a slight warming associated with the positive phase of these modes. There is a positive correlation between precipitation in the region, on the one hand, and Nino3.4 and the IPO, and to a lesser extent also the TSA, on the other hand. The ENSO frequency influences the interannual variability in precipitation and may affect the vegetation in the region where the duration of the dry season is more important than temperature.

Findings from the pampean plain (three study sites reviewed; Fig. 12):

- Moisture balance and temperature: fossil pollen records are moisture sensitive and do not detect temperature shifts. From 2 to $0.7-0.4 \mathrm{ka}$, drier climatic conditions than at present are inferred, while after $0.3 \mathrm{ka}$ a noticeable increase in precipitation occurred (more positive moisture balance).

- Humans: all records have human impact but this widespread impact only occurs during the last $0.1 \mathrm{kyr}$, and is a consequence of the introduction of exotic tree species such as Eucalyptus and Pinus.

- Climate modes: models suggest that the climate modes explored here exert only weak influences over the pampean region. Precipitation seasonality probably plays a more important role as moisture supply stems from distinct sources during the year.

Findings from the Southern Andes and Patagonia (23 study sites reviewed; Fig. 13):

- Moisture balance and temperature: fossil pollen records are both a moisture and a temperature sensitive, showing a highly diverse pattern of alternating phases during the last 2 kyr. One record displays a major ENSO frequency between $1.8-1.3$ and $0.7-0.3 \mathrm{ka}$.

- Humans: impact is present in most records (17 out of 23). Only the last centuries show clear human intervention associated with European arrival through the occurrence of Plantago (indicator of overgrazing), increased grasses, introduced taxa (Pinus), and crop-related herbs (Rumex). European colonization followed a clear north to south migration pattern, while evidence for the presence of earlier human populations in the region is not conclusive from palaeoecological records.

- Climate modes: the strongest influence in the region is exerted by the SAM for both temperature and precipitation. The pollen records are considered to mainly reflect changes in the southern westerly wind belt and hence to be indicative of the SAM. ENSO influences mostly precipitation.

\subsection{General conclusions}

On the basis of the region-by-region assessments from SA we conclude more generally that 
- the low number of SA records that fulfill all the PAGES$2 \mathrm{k}$ criteria (only 44 ) is a consequence of the age and quantity of the sediments recovered (which place fundamental limits on the duration and resolution of any study) and of the focus of the original research. Many SA records have been excluded because their long time span (> $10 \mathrm{ka}$ ) coupled with a relatively slow sedimentation allows only low temporal resolution of sampling; furthermore, slow sedimentation rates mean that many records do not have radiocarbon ages from within the last $2 \mathrm{kyr}$.

- pollen records in SA can detect long-distance (between sites) synchronicity (differences and similarities) in vegetation changes as an indication of regional precipitation and temperature variability; however, they can also detect the local-scale change or variability, which needs to be understood to determine whether a long-distance signal is present. This interaction between long-distance and local-scale signal has long been a problem for palynologists (e.g. Jacobson and Bradshaw, 1981), but interestingly in SA it seems that the degree of variation in signal varies between regions, i.e. in lowland regions there seems to be less between-site variability (consistent long-distance signal) compared with Andean sites (high local-site-specific variability). This variation between lowland and Andean sites is probably a function of topographic complexity and hence lowland pollen records provide a relatively cleaner long-distance signal, from which large-scale atmospheric circulation (climate) change can be assessed. However, we show that fossil pollen records from all regions of SA can be compared to help better understand past changes in the intensity and area of influence of different climate modes, such as ENSO or the AMO.

- throughout SA a number of overlapping climate modes operate. We assess the correlation and regression coefficients of the six most relevant climate modes to identify the modes with the most significant influence on interannual temperature and precipitation variability. Every single pollen record most likely captures the signal of various climate modes (Figs. 2-5), although they do not all operate in the same frequency bands and modes interact with one another through constructive interference. The causes of ambiguous climate-vegetation responses observed in pollen records can therefore probably be ascribed to the degree of climate mode interaction at a given location and to the degree of climate mode interaction interaction with non-climate variables (e.g. ecological interactions and natural hazards).

- the geographical location (latitude, longitude, and altitude) of a record naturally affects the sensitivity of a study site to temperature- or precipitation-related forcing (Figs. 7-13). The baseline for understanding climate-driven changes in vegetation is related to either of these variables, but interpreting pollen records in terms of a response to large-scale climatic forcing may yield further insights as it allows an attribution of temperature- and/or precipitation-driven changes to forcing from climate modes originating in either the Atlantic or Pacific Ocean.

\section{Recommendations}

Below we list a few specific recommendations for future engagements between climate- and pollen-related studies.

1. Quantitative translation from pollen metrics to climate variables: assembling a meaningful multisite and multiproxy data set is hampered by the current gap between the palynological and the climate dynamics and modelling community, both in terms of interpretation and quantitative translation of pollen data into climate indicators. This gap can be narrowed when pollen studies provide their own temperature or precipitation approximations if the data are suitable for that purpose. There are only a few pollen studies that provide a quantitative interpretation of their pollen data in terms of a climate variable. In the Andes, La Cocha-1 (González et al., 2012) and Papallacta PA1-08 (Ledru et al., 2013a) provide such estimates of climatological changes. In both cases the percentage of arboreal pollen was used as a measurement of moisture or temperature changes. Similarly Punyasena et al. (2008) and Whitney et al. (2011) present innovative methodologies for climate reconstructions in the lowland tropics, as do Markgraf et al. (2002), Tonello and Prieto (2008), Tonello et al. (2009, 2010), and Schäbitz et al. (2013) in southern SA. Providing additional climate estimates is not a common feature in palynological studies, and this missing link becomes more obvious when the palynological community is being engaged in a multidisciplinary effort such as LOTRED-SA and PAGES-2k.

2. Multi-proxy based research should become a mandatory goal for all further investigations. Caution should be exercized when interpreting apparently contradictory records provided by different groups for the same region; the interpretation of climatic and anthropogenic signals in each record may be based on very different (indirect) proxies. Hence, the apparent asynchronies or contradictory interpretations could simply occur as a result of methodological artefacts (e.g. by not including charcoal records, non-pollen palynomorphs, geochemical analyses). On the other hand, multi-proxy based research is especially relevant for those areas where human impact has been found for the last $2 \mathrm{kyr}$, but a climatic interpretation is the aim of the study. Developing proxies suitable for generating independent climate reconstructions from lake sediments in SA in- 
cludes considering chironomids (Matthews-Bird et al., 2015; Williams et al., 2012), while indications of humans can come from non-pollen palynomorphs, such as the dung fungus Sporormiella (Williams et al., 2011).

3. For the stated purposes of the current and future PAGES initiatives, researchers should be motivated to further improve chronologies for existing sites. There is a need to increase efforts in high-resolution studies with an accurate chronology for the last $2 \mathrm{kyr}$. At the same time, the PAGES-2k criteria should be adjusted for pollen records, especially by applying a lower threshold of dating criteria. A region such as the lowland Amazon is notorious for its paucity of records with good dating (e.g. Ledru et al., 1998). Therefore, additional valuable sites available should be considered for the overall purpose of studying vegetation-climate linkages.

4. Further advances in understanding climate-human relationships are also likely to be made by the integration of palaeoecological and archaeological data (e.g. Mayle and Iriarte, 2014) through conceptual modelling, which can provide a framework for identifying patterns and trajectories of change (e.g. Gosling and Williams, 2013).

5. Multi-proxy studies should compare data between different regions and records that are comparable in terms of chronology and resolution. Comparisons may yield insight into anti-phased climate variability resulting from certain dominant climate modes (e.g. a comparison between the coast of Colombia and NE BrazilGuayanas, on the one hand, and S Brazil and E Argentina, on the other).

6. All Andean zones are quite active from tectonic and volcanic points of view, and those drivers will have had significant impacts on the vegetation and maybe in the fossil pollen records as well. However, this aspect was only discussed for the southern region of the Andes. A chronology database focused on tephra control points could support current chronology constraints and improve comparison between records. The recent geochronological database within the LAPD can support such a multi-proxy approach for palaeoecological integration (Flantua et al., 2016).

7. In this paper we focused less on the seasonal contrasts throughout the continent, but in southern SA the seasonal component is extremely important, as precipitation shifts latitudinally over the course of the year. Precipitation in this region is the limiting factor for vegetation growth and pollen production. Key issues that need further study include (a) a better understanding of the relationship between winter and summer rainfall, (b) the question of whether this relationship has remained stationary over the last $2 \mathrm{kyr}$, and (c) the question of whether changes in the intensity or location (latitudinal shift) of rainfall have occurred.

8. High-resolution time series should be explored with frequency analysis to find support for operating climate modes.

9. Optimal exploration of the presence of climate modes in pollen records requires a specific research design. Temporal resolution should be increased to below decadal scale, chronological control of the sediments should be optimized, and the main frequencies in the time series should be analysed and compared with a frequency spectrum to be developed that shows characteristics of the climate modes.

\section{The Supplement related to this article is available online at doi:10.5194/cp-12-483-2016-supplement.}

Author contributions. S. G. A. Flantua, C. González-Arango, and $\mathrm{H}$. Hooghiemstra conceived the paper, and H. Hooghiemstra supervised the project. M. Vuille developed the climate modes and corresponding figures, supported the climate interpretations at a regional level, and edited the English of this paper. I. Hoyos supported the interpretation of the climate settings of the $\mathrm{N}$ and $\mathrm{C}$ Andes. V. Rull and E. Montoya carried out the palaeoecological and climate interpretation of the Venezuelan Guayana. S. G. A. Flantua, V. Rull, and H. Hooghiemstra carried out that of the N Andes sections. W. D. Gosling and M. P. Ledru carried out that of the C Andes sections. H. Behling carried out that of the $\mathrm{S}$ and SE Brazil sections. J. F. Carson, F. Mayle, and B. S. Whitney carried out that of the lowland Amazon sections. A. Maldonado and M. S. Tonello carried out that of the Patagonia and the S Andes sections. M. S. Tonello carried out that of the pampas sections. C. González-Arango and S. G. A. Flantua provided the initial drafts of the climate summary figures, and all authors discussed the results and implications. S. G. A. Flantua, C. González-Arango, M. Vuille, B. S. Whitney, J. F. Carson, W. D. Gosling, and H. Hooghiemstra structured and edited the manuscript during all phases.

Acknowledgements. We thank the Netherlands Organization for Scientific Research (NWO, grant 2012/13248/ALW) for financial support for the project of Suzette Flantua. We are grateful for the support provided to Mathias Vuille by NSF-P2C2 (AGS-1303828) and to Encarni Montoya by the NERC fellowship (NE/J018562/1). Isabel Hoyos is supported by the USAID-NSF PEER program, project 31, and CODI Universidad de Antioquia. For the set-up of the LAPD, we would like to thank the Amsterdam-based Hugo de Vries Foundation for supporting this work between 2009 and 2012 by three grants. We appreciate the interesting and constructive comments on the Climate of the Past Discussion version of this paper raised by the reviewers Vera Markgraf, Gonzalo Sottile, and Virginia Iglesias. Special thanks go out to Martin Grosjean, 
Ricardo Villalba, José Ignacio Martínez, Catalina González, and Thorsten Kiefer for organizing the LOTRED-SA Special Issue "Climate change and human impact in Central and South America over the last 2000 years" and for allowing us to submit our work to it ((http://www.clim-past.net/special_issue84.html).

Edited by: R. Villalba

\section{References}

Andreoli, R. V. and Kayano, M. T.: ENSO-related rainfall anomalies in South America and associated circulation features during warm and cold Pacific decadal oscillation regimes, Int. J. Climatol., 25, 2017-2030, 2005.

Bakker, J.: Tectonic and climatic controls on Late Quaternary sedimentary processes in a neotectonic intramontane basin (the Pitalito Basin, South Colombia), Landbouwuniversiteit Wageningen, Wageningen, 1990.

Bakker, J., Moscol-Olivera, M., and Hooghiemstra, H.: Holocene environmental change at the upper forest line in northern Ecuador, The Holocene, 18, 877-893, 2008.

Barros V., Clarke, R., and Dias, P. S.: Climate Change in the La Plata Basin. Publication of the Inter-American Institute for Global Change Research (IAI), São José dos Campos, Brazil, 34 pp., 2006.

Behling, H.: A high resolution Holocene pollen record from Lago do Pires, SE Brazil: vegetation, climate and fire history, J. Paleolimnol., 14, 253-268, 1995.

Behling, H.: Late glacial and Holocene vegetation, climate and fire history inferred from Lagoa Nova in the southeastern Brazilian lowland, Veg. Hist. Archaeobot., 12, 263-270, 2003.

Behling, H. and Da Costa, M. L.: Holocene Environmental Changes from the Rio Curuá Record in the Caxiuanã Region, Eastern Amazon Basin, Quat. Res., 53, 369-377, 2000.

Behling, H. and Da Costa, M. L.: Holocene vegetational and coastal environmental changes from the Lago Crispim record in northeastern Pará State, eastern Amazonia, Rev. Palaeobot. Palynol., 114, 145-155, 2001.

Behling, H. and Hooghiemstra, H.: Late Quaternary palaeoecology and palaeoclimatology from pollen records of the savannas of the Llanos Orientales in Colombia, Palaeogeogr. Palaeoclimatol. Palaeoecol., 139, 251-267, 1998.

Behling, H. and Hooghiemstra, H.: Environmental history of the Colombian savannas of the Llanos Orientales since the Last Glacial Maximum from lake records El Piñal and Carimagua, J. Paleolimnol., 21, 461-476, 1999.

Behling, H. and Hooghiemstra, H.: Holocene Amazon rainforestsavanna dynamics and climatic implications: high-resolution pollen record from Laguna Loma Linda in eastern Colombia, J. Quat. Sci., 15, 687-695, 2000.

Behling, H. and Pillar, V. D.: Late Quaternary vegetation, biodiversity and fire dynamics on the southern Brazilian highland and their implication for conservation and management of modern Araucaria forest and grassland ecosystems, Philos. Trans. R. Soc. B Biol. Sci., 362, 243-251, 2007.

Behling, H. and Safford, H. D.: Late-glacial and Holocene vegetation, climate and fire dynamics in the Serra dos Órgãos, Rio de Janeiro State, southeastern Brazil: Late Quaternary environmental dynamics, Glob. Change Biol., 16, 1661-1671, 2010.
Behling, H., Hooghiemstra, H., and Negret, A. J.: Late Quaternary vegetational and climatic change in the Popyan region, southern Colombian Andes, J. Quaternary Sci., 13, 43-53, 1997.

Behling, H., Hooghiemstra, H., and Negret, A.: Holocene history of the Chocó rain forest from Laguna Piusbi, Southern Pacific lowlands of Colombia, Quat. Res., 50, 300-308, 1998a.

Behling, H., Negret, A. J., and Hooghiemstra, H.: Late Quaternary vegetational and climatic change in the Popayán region, southern Colombian Andes, J. Quat. Sci., 13, 43-53, 1998 b.

Behling, H., Pillar, V. D., and Bauermann, S. G.: Late Quaternary grassland (Campos), gallery forest, fire and climate dynamics, studied by pollen, charcoal and multivariate analysis of the São Francisco de Assis core in western Rio Grande do Sul (southern Brazil), Rev. Palaeobot. Palynol., 133, 235-248, 2005.

Behling, H., Pillar, V. D., Müller, S. C., and Overbeck, G. E.: LateHolocene fire history in a forest-grassland mosaic in southern Brasil: Implications for conservation, Appl. Vegetat. Sci., 10, 8190, 2007.

Bellwood, P.: First Farmers: The Origins of Agricultural Societies, Wiley, Malden, 2004.

Berrío, J. C., Hooghiemstra, H., Behling, H., and Van der Borg, K.: Late Holocene history of savanna gallery forest from Carimagua area, Colombia, Rev. Palaeobot. Palynol., 111, 295-308, 2000.

Berrío, J. C., Hooghiemstra, H., Behling, H., Botero, P., and Van der Borg, K.: Late-Quaternary savanna history of the Colombian Llanos Orientales from Lagunas Chenevo and Mozambique: a transect synthesis, The Holocene, 12, 35-48, 2002.

Berrio, J. C., Hooghiemstra, H., Marchant, R., and Rangel, O.: Lateglacial and Holocene history of the dry forest area in the south Colombian Cauca Valley, J. Quaternary Sci., 17, 667-682, 2002.

Berry, P. E., Huber, O., and Holst, B. K.: Floristic analysis and phytogeography, in: Flora of the Venezuelan Guayana, vol. 1. Introduction, edited by: Berry, P. E., Holst, B. K., and Yatskievych, K., Missouri Botanical Garden Press, St. Louis, 161-191, 1995.

Bogotá-A., R. G., Groot, M. H. M., Hooghiemstra, H., Lourens, L. J., Van der Linden, M., and Berrío, J. C.: Rapid climate change from north Andean Lake Fúquene pollen records driven by obliquity: implications for a basin-wide biostratigraphic zonation, Quat. Sci. Rev., 30, 3321-3337, 2011.

Boninsegna, J. A., Argollo, J., Aravena, J. C., Barichivich, J., Christie, D., Ferrero, M. E., Lara, A., Le Quesne, C., Luckman, B. H., Masiokas, M., Morales, M., Oliveira, J. M., Roig, F., Srur, A., and Villalba, R.: Dendroclimatological reconstructions in South America: A review, Palaeogeogr. Palaeoclimatol. Palaeoecol., 281, 210-228, 2009.

Branch, N. P., Kemp, R. A., Silva, B., Meddens, F. M., Williams, A., Kendall, A., and Pomacanchari, C. V.: Testing the sustainability and sensitivity to climatic change of terrace agricultural systems in the Peruvian Andes: a pilot study, J. Archaeol. Sci., 34, 1-9, 2007.

Briceño, H., Schubert, C., and Paolini, J.: Table-mountain geology and surficial geochemistry: Chimantá Massif, Venezuelan Guayana shield, J. South Am. Earth Sci., 3, 179-194, 1990.

Burbridge, R. E., Mayle, F. E., and Killeen, T. J.: Fifty-thousandyear vegetation and climate history of Noel Kempff Mercado National Park, Bolivian Amazon, Quat. Res., 61, 215-230, 2004.

Bush, M. B. and Rivera, R.: Reproductive ecology and pollen representation among neotropical trees, Glob. Ecol. Biogeogr., 10, 359-367, 2001. 
Bush, M. B., De Oliveira, P. E., Colinvaux, P. A., Miller, M. C., and Moreno, J. E.: Amazonian paleoecological histories: one hill, three watersheds, Palaeogeogr. Palaeoclimatol. Palaeoecol., 214, 359-393, 2004.

Bush, M. B., Silman, M. R., and Listopad, C. M. C. S.: A regional study of Holocene climate change and human occupation in Peruvian Amazonia: Amazonian climate change and settlement, J. Biogeogr., 34, 1342-1356, 2007a.

Bush, M. B., Silman, M. R., de Toledo, M. B., Listopad, C., Gosling, W. D., Williams, C., de Oliveira, P. E., and Krisel, C.: Holocene fire and occupation in Amazonia: records from two lake districts, Phil. Trans. R. Soc. B, 362, 209-218, 2007b.

Carson, J. F., Whitney, B. S., Mayle, F. E., Iriarte, J., Prümers, H., Soto, J. D., and Watling, J.: Environmental impact of geometric earthwork construction in pre-Columbian Amazonia, Proc. Natl. Acad. Sci., 111, 10497-10502, 2014.

Carson, J. F., Watling, J., Mayle, F. E., Whitney, B. S., Iriarte, J., Prümers, H., and Soto, J. D.: Pre-Columbian land use in the ringditch region of the Bolivian Amazon, The Holocene, 25, 12851300, 2015.

Carvalho, L. M. V., Jones, C., and Ambrizzi, T.: Opposite phases of the Antarctic Oscillation and relationships with intraseasonal to interannual activity in the tropics during the Austral Summer, J. Clim., 18, 702-718, 2005.

Cheng, H., Sinha, A., Cruz, F. W., Wang, X., Edwards, R. L., d' Horta, F. M., Ribas, C. C., Vuille, M., Stott, L. D., and Auler, A. S.: Climate change patterns in Amazonia and biodiversity, Nat. Commun., 4, 1411, doi:10.1038/ncomms2415, 2013.

Chepstow-Lusty, A.: Agro-pastoralism and social change in the Cuzco heartland of Peru: a brief history using environmental proxies, Antiquity, 85, 570-582, 2011.

Chepstow-Lusty, A. and Jonsson, P.: Inca agroforestry: lessons from the past, AMBIO J. Hum. Environ., 29, 322-328, 2000.

Chepstow-Lusty, A. J., Bennett, K. D., Switsur, V. R., and Kendall, A.: 4000 years of human impact and vegetation change in the central Peruvian Andes - with events parallelling the Maya record?, Antiquity, 70, 824-833, 1996.

Chepstow-Lusty, A. J., Bennett, K. D., Fjeldså, J., Kendall, A., Galiano, W., and Herrera, A. T.: Tracing 4,000 Years of environmental history in the Cuzco area, Peru, from the pollen record, Mount. Res. Dev., 18, 159-172, 1998.

Chepstow-Lusty, A. J., Frogley, M. R., Bauer, B. S., Leng, M. J., Boessenkool, K. P., Carcaillet, C., Ali, A. A., and Gioda, A.: Putting the rise of the Inca Empire within a climatic and land management context, Clim. Past, 5, 375-388, doi:10.5194/cp-5375-2009, 2009.

Chepstow-Lusty, A., Frogley, M. R., Bauer, B. S., Bush, M. B., and Herrera, A. T.: A late Holocene record of arid events from the Cuzco region, Peru, J. Quat. Sci., 18, 491-502, 2003.

Cohen, M. C. L., Pessenda, L. C. R., Behling, H., de Fátima Rossetti, D., França, M. C., Guimarães, J. T. F., Friaes, Y., and Smith, C. B.: Holocene palaeoenvironmental history of the Amazonian mangrove belt, Quat. Sci. Rev., 55, 50-58, 2012.

Colinvaux, P. A. and Schofield, E. K.: Historical ecology in the Galapagos Islands: I. A Holocene pollen record from El Junco Lake, Isla San Cristobal, J. Ecol., 64, 989-1012, 1976.

Colson, A. B.: Routes of knowledge, an aspect of regional integration in the circum-Roraima area of the Guayana highlands, Antropológica, 63/64, 103-149, 1985.
Curtis, S. and Hastenrath, S.: Forcing of anomalous sea surface temperature evolution in the tropical Atlantic during Pacific warm events, J. Geophys. Res. Oceans, 100, 15835-15847, 1995.

D’Apolito, C., Absy, M. L., and Latrubesse, E. M.: The Hill of Six Lakes revisited: new data and re-evaluation of a key Pleistocene Amazon site, Quat. Sci. Rev., 76, 140-155, 2013.

Da Silva Meneses, M. E. N., da Costa, M. L., and Behling, H.: Late Holocene vegetation and fire dynamics from a savanna-forest ecotone in Roraima state, northern Brazilian Amazon, J. South Am. Earth Sci., 42, 17-26, 2013.

De Porras, M. E., Maldonado, A., Abarzúa, A. M., Cárdenas, M. L., Francois, J. P., Martel-Cea, A., Stern, C. R., Méndez, C., and Reyes, O.: Postglacial vegetation, fire and climate dynamics at Central Chilean Patagonia (Lake Shaman, $44^{\circ}$ S), Quat. Sci. Rev., 50, 71-85, 2012.

De Porras, M. E., Maldonado, A., Quintana, F. A., Martel-Cea, A., Reyes, O., and Méndez, C.: Environmental and climatic changes in central Chilean Patagonia since the Late Glacial (Mallín El Embudo, 44 S), Clim. Past, 10, 1063-1078, doi:10.5194/cp-101063-2014, 2014.

De Toledo, M. B. and Bush, M. B.: A mid-Holocene environmental change in Amazonian savannas: A mid-Holocene environmental change in Amazonian savannas, J. Biogeogr., 34, 1313-1326, 2007.

Dillehay, T. D., Eling, H. H., and Rossen, J.: Preceramic irrigation canals in the Peruvian Andes, Proc. Natl. Acad. Sci. USA, 102, 17241-17244, 2005.

Doyle, M. E. and Barros, V. R.: Midsummer low-level circulation and precipitation in subtropical South America and related sea surface temperature anomalies in the South Atlantic, J. Clim., 15, 3394-3410, 2002.

Echeverria, M. E., Sottile, G. D., Mancini, M. V., and Fontana, S. L.: Nothofagus forest dynamics and palaeoenvironmental variations during the mid and late Holocene, in southwest Patagonia, The Holocene, 24, 957-969, 2014.

Enfield, D. B., Mestas-Nuñez, A. M., Mayer, D. A., and CidSerrano, L.: How ubiquitous is the dipole relationship in tropical Atlantic sea surface temperatures?, J. Geophys. Res. Oceans, 104, 7841-7848, 1999.

Enfield, D. B., Mestas-Nuñez, A. M., and Trimble, P. J.: The Atlantic Multidecadal Oscillation and its relation to rainfall and river flows in the continental US, Geophys. Res. Lett., 28, 20772080, 2001.

Espinoza Villar, J. C., Ronchail, J., Guyot, J. L., Cochonneau, G., Naziano, F., Lavado, W., De Oliveira, E., Pombosa, R., and Vauchel, P.: Spatio-temporal rainfall variability in the Amazon basin countries (Brazil, Peru, Bolivia, Colombia, and Ecuador), Int. J. Climatol., 29, 1574-1594, 2009.

Fjeldså, J. and Kessler, M.: Conserving the biological diversity of Polylepis woodlands of the highland of Peru and Bolivia. A contribution to sustainable natural resource management in the Andes, Nordic Agency for Development and Ecology NORDECO, Copenhagen, 1996.

Flantua, S. G. A., Hooghiemstra, H., Grimm, E. C., Behling, H., Bush, M. B., González-Arango, C., Gosling, W. D., Ledru, M. P., Lozano-García, S., Maldonado, A., Prieto, A. R., Rull, V., and Van Boxel, J. H.: Updated site compilation of the Latin American Pollen Database, Rev. Palaeobot. Palynol., 223, 104-115, 2015. 
Flantua, S. G. A., Blaauw, M., and Hooghiemstra, H.: Geochronological database and classification system for age uncertainties in Neotropical Pollen records, Clim. Past, accepted, 2016.

Fletcher, M.-S. and Moreno, P. I.: Vegetation, climate and fire regime changes in the Andean region of southern Chile $\left(38^{\circ} \mathrm{S}\right)$ covaried with centennial-scale climate anomalies in the tropical Pacific over the last 1500 years, Quat. Sci. Rev., 46, 46-56, 2012.

Folland, C. K., Renwick, J. A., Salinger, M. J., and Mullan, A. B.: Relative influences of the Interdecadal Pacific Oscillation and ENSO on the South Pacific Convergence Zone, Geophys. Res. Lett., 29, 21-1, 2002.

Fontana, S. L.: Holocene vegetation history and palaeoenvironmental conditions on the temperate Atlantic coast of Argentina, as inferred from multi-proxy lacustrine records, J. Paleolim., 34, 445-469, 2005.

Garralla, S. S.: Análisis polínico de una secuencia sedimentaria del Holoceno Tardío en el Abra del Infiernillo, Tucumán, Argentina, Polen, 12, 53-63, 2003.

Garreaud, R. and Battisti, D. S.: Interannual (ENSO) and Interdecadal (ENSO-like) Variability in the Southern Hemisphere Tropospheric Circulation*, J. Clim., 12, 2113-2123, 1999.

Garreaud, R., Vuille, M., and Clement, A. C.: The climate of the Altiplano: Observed current conditions and mechanisms of past changes, Palaeogeogr. Palaeoclimatol. Palaeoecol., 194, 5-22, 2003.

Garreaud, R., Lopez, P., Minvielle, M., and Rojas, M.: Large-scale control on the Patagonian climate, J. Clim., 26, 215-230, 2013.

Garreaud, R. D., Vuille, M., Compagnucci, R., and Marengo, J.: Present-day South American climate, Palaeogeogr. Palaeoclimatol. Palaeoecol., 281, 180-195, 2009.

Ghersa, C. M. and León, R. J. C.: Ecología del paisaje Pampeano: consideraciones para su manejo y conservación, in: Ecología de Paisajes., edited by: Naveh, Z. and Lieberman, A. S., Editorial Facultad de Agronomía, Buenos Aires, 471-512, 2001.

Giannini, A., Chiang, J. C. H., Cane, M. A., Kushnir, Y., and Seager, R.: The ENSO teleconnection to the tropical Atlantic Ocean: contributions of the remote and local SSTs to rainfall variability in the tropical Americas, J. Clim., 14, 4530-4544, 2001.

Gillett, N. P., Kell, T. D., and Jones, P. D.: Regional climate impacts of the Southern Annular Mode, Geophys. Res. Lett., 33, L23704, doi:10.1029/2006GL027721, 2006.

González, C., Dupont, L. M., Behling, H., and Wefer, G.: Neotropical vegetation response to rapid climate changes during the last glacial period: Palynological evidence from the Cariaco Basin, Quaternary Res., 69, 217-230, 2008.

González-Carranza, Z., Hooghiemstra, H., and Vélez, M. I.: Major altitudinal shifts in Andean vegetation on the Amazonian flank show temporary loss of biota in the Holocene, The Holocene, 22, 1227-1241, 2012.

Gosling, W. D. and Williams, J. J.: Ecosystem service provision sets the pace for pre-Hispanic societal development in the central Andes, The Holocene, 23, 1619-1624, 2013.

Grimm, A. M., Barros, V. R., and Doyle, M. E.: Climate variability in southern South America associated with El Niño and La Niña events, J. Clim., 13, 35-58, 2000.

Groot, M. H. M., Hooghiemstra, H., Berrio, J. C., and Giraldo, C.: North Andean environmental and climatic change at orbital to submillennial time-scales: vegetation, water levels and sedimen- tary regimes from Lake Fúquene 130-27 ka, Rev. Palaeobot. Palynol., 197, 186-204, 2013.

Gupta, A. S. and England, M. H.: Coupled ocean-atmosphere-ice response to variations in the Southern Annular Mode, J. Clim., 19, 4457-4486, 2006.

Hastenrath, S. and Greischar, L.: Circulation mechanisms related to northeast Brazil rainfall anomalies, J. Geophys. Res. Atmospheres, 98, 5093-5102, 1993.

Hermanowski, B., da Costa, M. L., and Behling, H.: Environmental changes in southeastern Amazonia during the last 25,000 yr revealed from a paleoecological record, Quat. Res., 77, 138-148, 2012.

Heusser, C. J.: Late Quaternary forest-steppe contact zone, Isla Grande de Tierra del Fuego, subantarctic South America., Quat. Sci. Rev., 12, 169-177, 1993.

Hillyer, R., Valencia, B. G., Bush, M. B., Silman, M. R., and Steinitz-Kannan, M.: A 24,700-yr paleolimnological history from the Peruvian Andes, Quat. Res., 71, 71-82, 2009.

Huber, O.: Recent advances in the phytogeography of the Guayana region, South America, Mém, Société Biogéographique, 3, 5363, 1994.

Huber, O.: Geographical and physical features, in: Flora of the Venezuelan Guayana, vol. 1. Introduction, edited by: Berry, P. E., Holst, B. K., and Yatskievych, K., Missouri Botanical Garden Press, St. Louis, 1-62, 1995a.

Huber, O.: Vegetation, in: Flora of the Venezuelan Guayana, vol. 1. Introduction, edited by: Berry, P. E., Holst, B. K., and Yatskievych, K., Missouri Botanical Garden Press, St. Louis, 97 160, 1995b.

Huber, O. and Riina, R.: Glosario fitoecológico de las Américas: América del Sur: países hispanoparlantes, Tamandúa, UNESCO; Fundación Instituto Botánico de Venezuela, Caracas, Venezuela, 1997.

Huber, O. and Febres, G.: Guía ecológica de la Gran Sabana, 1st ed., The Nature Conservancy, Caracas, Venezuela, 2000.

Huber, U. M. and Markgraf, V.: European impact on fire regimes and vegetation dynamics at the steppe-forest ecotone of southern Patagonia, The Holocene, 13, 567-579, 2003.

Iglesias, V. and Whitlock, C.: Fire responses to postglacial climate change and human impact in northern Patagonia $\left(41-43^{\circ} \mathrm{S}\right)$, Proc. Natl. Acad. Sci. USA, 111, E5545-5554, 2014.

Iriarte, J., Power, M. J., Rostain, S., Mayle, F. E., Jones, H., Watling, J., Whitney, B. S., and McKey, D. B.: Fire-free land use in pre1492 Amazonian savannas, Proc. Natl. Acad. Sci., 109, 64736478, 2012.

Jacobson, G. L. and Bradshaw, R. H. W.: The selection of sites for paleovegetational studies, Quaternary Res., 16, 80-96, 1981.

Jantz, N. and Behling, H.: A Holocene environmental record reflecting vegetation, climate, and fire variability at the Páramo of Quimsacocha, southwestern Ecuadorian Andes, Veg. Hist. Archaeobot., 21, 169-185, 2012.

Jara, I. A. and Moreno, P. I.: Temperate rainforest response to climate change and disturbance agents in northwestern Patagonia $\left(41^{\circ} \mathrm{S}\right)$ over the last 2600 years, Quat. Res., 77, 235-244, 2012.

Jara, I. A. and Moreno, P. I.: Climatic and disturbance influences on the temperate rainforests of northwestern Patagonia $\left(40^{\circ} \mathrm{S}\right)$ since $\sim 14,500$ cal yr BP, Quat. Sci. Rev., 90, 217-228, 2014.

Jeske-Pieruschka, V. and Behling, H.: Palaeoenvironmental history of the São Francisco de Paula region in southern Brazil during 
the late Quaternary inferred from the Rincão das Cabritas core, The Holocene, 22, 1251-1262, 2012.

Jeske-Pieruschka, V., Fidelis, A., Bergamin, R. S., Vélez, E., and Behling, H.: Araucaria forest dynamics in relation to fire frequency in southern Brazil based on fossil and modern pollen data, Rev. Palaeobot. Palynol., 160, 53-65, 2010.

Jeske-Pieruschka, V., Pillar, V. D., De Oliveira, M. A. T., and Behling, H.: New insights into vegetation, climate and fire history of southern Brazil revealed by a 40,000 year environmental record from the State Park Serra do Tabuleiro, Veg. Hist. Archaeobot., 22, 299-314, 2013.

Kuentz, A., de Mera, A. G., Ledru, M.-P., and Thouret, J.-C.: Phytogeographical data and modern pollen rain of the puna belt in southern Peru (Nevado Coropuna, Western Cordillera), J. Biogeogr., 34, 1762-1776, 2007.

Kuentz, A., Ledru, M.-P., and Thouret, J.-C.: Environmental changes in the highlands of the western Andean Cordillera, southern Peru, during the Holocene, The Holocene, 22, 12151226, 2012.

Labraga, J. C., Scian, B., and Frumento, O.: Anomalies in the atmospheric circulation associated with the rainfall excess or deficit in the Pampa Region in Argentina, J. Geophys. Res.-Atmospheres, 107, 1-15, 2012.

Leal, A., Perez, T., and Bilbao, B.: Contribution to early Holocene vegetation and climate history of eastern Orinoco Llanos, Venezuela, from a palaeoecological record of a Mauritia Lf swamp, Acta Amaz., 41, 513-520, 2011.

Ledru, M. P.: Late Holocene rainforest disturbance in French Guiana, Rev. Palaeobot. Palynol., 115, 161-170, 2001.

Ledru, M. P., Bertraux, J., and Sifeddine, A.: Absence of Last Glacial Maximum records, Quat. Res., 49, 233-237, 1998.

Ledru, M.-P., Jomelli, V., Samaniego, P., Vuille, M., Hidalgo, S., Herrera, M., and Ceron, C.: The Medieval Climate Anomaly and the Little Ice Age in the eastern Ecuadorian Andes, Clim. Past, 9, 307-321, doi:10.5194/cp-9-307-2013, $2013 \mathrm{a}$.

Ledru, M.-P., Jomelli, V., Bremond, L., Ortuño, T., Cruz, P., Bentaleb, I., Sylvestre, F., Kuentz, A., Beck, S., Martin, C., Paillès, C., and Subitani, S.: Evidence of moist niches in the Bolivian Andes during the mid-Holocene arid period, The Holocene, 23, 1547-1559, 2013b.

Legates, D. R. and Willmott, C. J.: Mean seasonal and spatial variability in gauge-corrected, global precipitation, Int. J. Climatol., 10, 111-127, 1990.

Lewis, S. L., Brando, P. M., Phillips, O. L., Van der Heijden, G. M. F., and Nepstad, D.: The 2010 Amazon drought, Science, 331, 554-554, 2011.

Leyden, B. W.: Late Quaternary aridity and Holocene moisture fluctuations in the Lake Valencia Basin, Venezuela, Ecology, 66, 1279-1295, 1985.

Li, B., Nychka, D. W., and Ammann, C. M.: The value of multiproxy reconstruction of past climate, J. Am. Stat. Assoc., 105, 883-895, 2010.

$\mathrm{Li}, \mathrm{W}$. and $\mathrm{Fu}, \mathrm{R}$. . Influence of cold air intrusions on the wet season onset over Amazonia, J. Clim., 19, 257-275, 2006.

Liebmann, B. and Marengo, J.: Interannual variability of the rainy season and rainfall in the Brazilian Amazon basin, J. Clim., 14, 4308-4318, 2001.
Maldonado, A. and Villagrán, C.: Climate variability over the last 9900 cal yr BP from a swamp forest pollen record along the semiarid coast of Chile, Quat. Res., 66, 246-258, 2006.

Mancini, M. V.: Variabilidad climática durante los últimos 1000 años en el área de Cabo Vírgenes, Argentina, Ameghiniana, 44, 173-182, 2007.

Mancini, M. V.: Holocene vegetation and climate changes from a peat pollen record of the forest - steppe ecotone, southwest of Patagonia (Argentina), Quat. Sci. Rev., 28, 1490-1497, 2009.

Mancini, M. V. and Graham, M.: Registros polínicos de depósitos del Holoceno en el sudeste de Patagonia, Argentina: Su aplicación en la reconstrucción paleoambiental, Ameghiniana, 51, 194-208, 2014.

Mancini, M. V., Paez, M. M., and Prieto, A. R.: Cambios paleoambientales durante los ultimos $7000{ }^{14} \mathrm{C}$ años en el ecotono bosque'estepa, $47-48^{\circ} \mathrm{S}$, Santa Cruz, Argentina, Ameghiniana, 39, 151-162, 2002.

Marchant, R., Behling, H., Berrio, J. C., Cleef, A., Duivenvoorden, J., Hooghiemstra, H., Kuhry, P., Melief, B., Van Geel, B., and Van der Hammen, T.: Mid-to late-Holocene pollen-based biome reconstructions for Colombia, Quat. Sci. Rev., 20, 1289-1308, 2001.

Marchant, R., Almeida, L., Behling, H., Berrio, J. C., Bush, M., Cleef, A., Duivenvoorden, J., Kappelle, M., De Oliveira, P., Teixeira de Oliveira-Filho, A., Lozano-García, S., Hooghiemstra, H., Ledru, M. P., Ludlow-Wiechers, B., Markgraf, V., Mancini, V., Paez, M., Prieto, A., Rangel, O., and Salgado-Labouriau, M. L.: Distribution and ecology of parent taxa of pollen lodged within the Latin American Pollen Database, Rev. Palaeobot. Palynol., 121, 1-75, 2002.

Marengo, J. A., Nobre, C. A., Tomasella, J., Oyama, M. D., Sampaio de Oliveira, G., de Oliveira, R., Camargo, H., Alves, L. M., and Brown, I. F.: The drought of Amazonia in 2005, J. Clim., 21, 495-516, 2008.

Markgraf, V. and Huber, U. M.: Late and postglacial vegetation and fire history in southern Patagonia and Tierra del Fuego, Palaeogeogr. Palaeoclimatol. Palaeoecol., 297, 351-366, 2010.

Markgraf, V., Webb, R. S., Anderson, K. H., and Anderson, L.: Modern pollen/climate calibration for southern South America, Palaeogeogr. Palaeoclimatol. Palaeoecol., 181, 375-397, 2002.

Markgraf, V., Whitlock, C., and Haberle, S.: Vegetation and fire history during the last $18,000 \mathrm{cal}$ yr B.P. in southern Patagonia: Mallín Pollux, Coyhaique, Province Aisén $\left(45^{\circ} 41^{\prime} 30^{\circ} \mathrm{S}\right.$, $71^{\circ} 50^{\prime} 30^{\circ} \mathrm{W}, 640 \mathrm{~m}$ elevation), Palaeogeogr. Palaeoclimatol. Palaeoecol., 254, 492-507, 2007.

Martin, L., Bertaux, J., Correge, T., Ledru, M.-P., Mourguiart, P., Sifeddine, A., Soubies, F., Wirrmann, D., Suguio, K., and Turcq, B.: Astronomical forcing of contrasting rainfall changes in tropical South America between 12,400 and 8800 cal yr BP, Quaternary Res., 47, 117-122, 1997.

Matthews-Bird, F., Gosling, W. D., Coe, A. L., Bush, M., Mayle, F. E., Axford, Y., and Brooks, S. J.: Environmental controls on the distribution and diversity of lentic Chironomidae (Insecta: Diptera) across an altitudinal gradient in tropical South America, Ecol. Evolut., 6, 91-112, doi:10.1002/ece3.1833, 2015.

Mauquoy, D., Blaauw, M., Van Geel, B., Borromei, A., Quattrocchio, M., Chambers, F. M., and Possnert, G.: Late Holocene climatic changes in Tierra del Fuego based on multiproxy analyses of peat deposits, Quat. Res., 61, 148-158, 2004. 
Mayle, F. E. and Iriarte, J.: Integrated palaeoecology and archaeology - a powerful approach for understanding pre-Columbian Amazonia, J. Archaeol. Sci., 51, 54-64, 2014.

Mayle, F. E., Burbridge, R., and Killeen, T. J.: Millennial-scale dynamics of southern Amazonian rain forests, Science, 290, 22912294, 2000.

Mayr, C., Fey, M., Haberzettl, T., Janssen, S., Lücke, A., Maidana, N. I., Ohlendorf, C., Schäbitz, F., Schleser, G. H., Struck, U., Wille, M., and Zolitschka, B.: Palaeoenvironmental changes in southern Patagonia during the last millennium recorded in lake sediments from Laguna Azul (Argentina), Palaeogeogr. Palaeoclimatol. Palaeoecol., 228, 203-227, 2005.

McGlue, M. M., Silva, A., Zani, H., Corradini, F. A., Parolin, M., Abel, E. J., Cohen, A. S., Assine, M. L., Ellis, G. S., Trees, M. A., Kuerten, S., dos Santos, F. G., and Rasbold, G. G.: Lacustrine records of Holocene flood pulse dynamics in the Upper Paraguay River watershed (Pantanal wetlands, Brazil), Quat. Res., 78, 285-294, 2012.

Montecinos, A. and Aceituno, P.: Seasonality of the ENSO-related rainfall variability in central Chile and associated circulation anomalies, J. Clim., 16, 281-296, 2003.

Montoya, E. and Rull, V.: Gran Sabana fires (SE Venezuela): a palaeoecological perspective, Quat. Sci. Rev., 30, 3430-3444, 2011

Montoya, E., Rull, V., Nogué, S., and Díaz, W. A.: Paleoecología del Holoceno en la Gran Sabana, SE Venezuela: Análisis preliminar de polen y microcarbones en la Laguna Encantada, Collectanea Botanica, 28, 65-79, 2009.

Montoya, E., Rull, V., Stansell, N. D., Abbott, M. B., Nogué, S., Bird, B. W., and Díaz, W. A.: Forest-savanna-morichal dynamics in relation to fire and human occupation in the southern Gran Sabana (SE Venezuela) during the last millennia, Quaternary Res., 76, 335-344, 2011a.

Montoya, E., Rull, V., Stansell, N. D., Bird, B. W., Nogué, S., Vegas-vilarrúbia, T., Abbott, M. B., and Díaz, W. A.: Vegetation changes in the Neotropical Gran Sabana (Venezuela) around the Younger Dryas chron, J. Quat. Scien., 26, 207-218, 2011 b.

Moreno, P. I., François, J. P., Villa-Martínez, R. P., and Moy, C. M.: Millennial-scale variability in Southern Hemisphere westerly wind activity over the last 5000 years in SW Patagonia, Quat. Sci. Rev., 28, 25-38, 2009.

Moreno, P. I., Vilanova, I., Villa-Martínez, R., Garreaud, R. D., Rojas, M., and De Pol-Holz, R.: Southern Annular Mode-like changes in southwestern Patagonia at centennial timescales over the last three millennia, Nat. Commun., 5, 4375, doi:10.1038/ncomms5375, 2014.

Moscol-Olivera, M. C. and Hooghiemstra, H.: Three millennia upper forest line changes in northern Ecuador: pollen records and altitudinal vegetation distributions, Rev. Palaeobot. Palynol., $163,113-126,2010$

Neukom, R. and Gergis, J.: Southern Hemisphere high-resolution palaeoclimate records of the last 2000 years, The Holocene, 22, 501-524, 2012.

Neukom, R., Luterbacher, J., Villalba, R., Küttel, M., Frank, D., Jones, P. D., Grosjean, M., Esper, J., Lopez, L., and Wanner, H.: Multi-centennial summer and winter precipitation variability in southern South America: South American precipitation variability, Geophys. Res. Lett., 37, L14708, doi:10.1029/2010GL043680, 2010.
Niemann, H. and Behling, H.: Late Holocene environmental change and human impact inferred from three soil monoliths and the Laguna Zurita multi-proxi record in the southeastern Ecuadorian Andes, Veg. Hist. Archaeobot., 19, 1-15, 2010.

Niemann, H., Matthias, I., Michalzik, B., and Behling, H.: Late Holocene human impact and environmental change inferred from a multi-proxy lake sediment record in the Loja region, southeastern Ecuador, Quat. Int., 308/309, 253-264, 2013.

Nobre, P. and Shukla, J.: Variations of sea surface temperature, wind stress, and rainfall over the tropical Atlantic and South America, J. Clim., 9, 2464-2479, 1996.

Nogué, S., Rull, V., Montoya, E., Huber, O., and Vegas-Vilarrúbia, T.: Paleoecology of the Guayana Highlands (northern South America): Holocene pollen record from the Eruoda-tepui, in the Chimantá massif, Palaeogeogr. Palaeoclimatol. Palaeoecol., 281, 165-173, 2009.

Olson, D. M., Dinerstein, E., Wikramanayake, E. D., Burgess, N. D., V, G., Powell, N., Underwood, E. C., D, J. A., Itoua, I., Strand, H. E., Morrison, J.C., Loucks, C. J., Allnutt, T. F., Ricketts, T. H., Kura, Y., Lamoreux, J. F., Wettengel, W. W., Hedao, P., and Kassem, K. R.: Terrestrial ecoregions of the world: a new map of life on Earth, BioScience, 51, 933-938, 2010.

PAGES-2k Consortium: Continental-scale temperature variability during the past two millennia, Nat. Geosci., 6, 339-346, 2013.

Pesce, O. H. and Moreno, P. I.: Vegetation, fire and climate change in central-east Isla Grande de Chiloé $\left(43^{\circ} \mathrm{S}\right)$ since the Last Glacial Maximum, northwestern Patagonia, Quat. Sci. Rev., 90, 143-157, 2014.

Polissar, P. J., Abbott, M. B., Wolfe, A. P., Bezada, M., Rull, V., and Bradley, R. S.: Solar modulation of Little Ice Age climate in the tropical Andes, Proc. Natl. Acad. Sci., 103, 8937-8942, 2006.

Punyasena, S. W.: Estimating Neotropical palaeotemperature and palaeoprecipitation using plant family climatic optima, Palaeogeogr. Palaeoclimatol. Palaeoecol., 265, 226-237, 2008.

Punyasena, S. W., Eshel, G., and McElwain, J. C.: The influence of climate on the spatial patterning of Neotropical plant families, J. Biogeogr., 35, 117-130, 2008.

Rayner, N. A., Parker, D. E., Horton, E. B., Folland, C. K., Alexander, L. V., Rowell, D. P., Kent, E. C., and Kaplan, A.: Global analyses of sea surface temperature, sea ice, and night marine air temperature since the late nineteenth century, J. Geophys. Res. Atmospheres, 108, 4407, doi:10.1029/2002JD002670, 2003.

Rodbell, D. T.: An 15,000-year record of El Niño-driven alluviation in southwestern Ecuador, Science, 283, 516-520, 1999.

Ronchail, J., Cochonneau, G., Molinier, M., Guyot, J.-L., De Miranda Chaves, A. G., Guimarães, V., and de Oliveira, E.: Interannual rainfall variability in the Amazon basin and sea-surface temperatures in the equatorial Pacific and the tropical Atlantic oceans, Int. J. Climatol., 22, 1663-1686, 2002.

Roucoux, K. H., Lawson, I. T., Jones, T. D., Baker, T. R., Coronado, E. N. H., Gosling, W. D., and Lähteenoja, O.: Vegetation development in an Amazonian peatland, Palaeogeogr. Palaeoclimatol. Palaeoecol., 374, 242-255, 2013.

Rull, V.: Contribución a la paleoecología de Pantepui la Gran Sabana (Guayana Venezolana): clima, biogeografía, y ecología, Scientia Guaianae, 2, 1-133, 1991.

Rull, V.: A palynological record of a secondary succession after fire in the Gran Sabana, Venezuela, J. Quat. Sci., 14, 137-152, 1999. 
Rull, V.: Palaeovegetational and palaeoenvironmental trends in the summit of the Guaiquinima massif (Venezuelan Guayana) during the Holocene, J. Quat. Sci., 20, 135-145, 2005a.

Rull, V.: Vegetation and environmental constancy in the Neotropical Guayana Highlands during the last 6000 years?, Rev. Palaeobot. Palynol., 135, 205-222, 2005b.

Rull, V.: An evaluation of the Lost World and vertical displacement hypotheses in the Chimantá Massif, Venezuelan Guayana, Glob. Ecol. Biogeogr., 13, 141-148, 2004a.

Rull, V.: Is the "Lost World" really lost? Palaeoecological insights into the origin of the peculiar flora of the Guayana Highlands, Naturwissenschaften, 91, 139-142, 2004b.

Rull, V.: Long-term vegetation stability and the concept of potential natural vegetation in the Neotropics, J. Veg. Sci., 26, 603-607, 2015.

Rull, V. and Montoya, E.: Mauritia flexuosa palm swamp communities: natural or human-made? A palynological study of the Gran Sabana region (northern South America) within a neotropical context, Quat. Sci. Rev., 99, 17-33, 2014.

Rull, V. and Schubert, C.: The little ice age in the tropical Venezuelan Andes, Acta Científica Venez., 40, 71-73, 1989.

Rull, V., Salgado-Labouriau, M. L., Schubert, C., and Valastro Jr, S.: Late Holocene temperature depression in the Venezuelan Andes: Palynological evidence, Palaeogeogr. Palaeoclimatol. Palaeoecol., 60, 109-121, 1987.

Rull, V., Vegas, T., Nogué, S., and Montoya, E.: Bureaucratic obstruction of conservation science in the Guayana Highlands, Conserv. Biol., 22, 508-509, 2008.

Rull, V., Montoya, E., Nogué, S., and Huber, O.: Preliminary palynological analysis of a Holocene peat bog from Apakará-tepui (Chimantá Massif, Venezuelan Guayana), Collectanea Botanica, 30, 79-88, 2011.

Rull, V., Montoya, E., Nogué, S., Vegas-Vilarrúbia, T., and Safont, E.: Ecological palaeoecology in the neotropical Gran Sabana region: long-term records of vegetation dynamics as a basis for ecological hypothesis testing, Perspect. Plant Ecol. Evol. Syst., 15, 338-359, 2013.

Safont, E., Rull, V., Vegas-vilarrúbia, T., Holst, B. K, Huber, O., Nozawa, S., Vivas, Y., and Silva, A.: Establishing a baseline of plant diversity and endemism on a neotropical mountain summit for future comparative studies assessing upward migration: an approach from biogeography and nature conservation, Syst. Biodivers., 12, 292-314, 2014.

Safont, E., Rull, V., Vegas-Vilarrúbia, T., Montoya, E., Huber, O., and Holst, B. K. Late Holocene vegetation and fire dynamics in the Guayana Highlands: the Uei-tepui palynological record, Vegetation history and Archaeobotany, accepted, , 2016.

Schäbitz, F., Wille, M., Francois, J.-P., Haberzettl, T., Quintana, F., Mayr, C., Lücke, A., Ohlendorf, C., Mancini, V., Paez, M. M., Prieto, A. R., and Zolitschka, B.: Reconstruction of palaeoprecipitation based on pollen transfer functions - the record of the last $16 \mathrm{ka}$ from Laguna Potrok Aike, southern Patagonia, Quat. Sci. Rev., 71, 175-190, 2013.

Schittek, K., Forbriger, M., Mächtle, B., Schäbitz, F., Wennrich, V., Reindel, M., and Eitel, B.: Holocene environmental changes in the highlands of the southern Peruvian Andes $\left(14^{\circ} \mathrm{S}\right)$ and their impact on pre-Columbian cultures, Clim. Past, 11, 27-44, doi:10.5194/cp-11-27-2015, 2015.
Silverman, H.: Andean Archaeology III: North and South, Springer US, NY, 2008.

Silvestri, G. E. and Vera, C. S.: Antarctic Oscillation signal on precipitation anomalies over southeastern South America, Geophys. Res. Lett., 30, 2115, doi:10.1029/2003GL018277, 2003.

Stutz, S., Borel, C. M., Fontana, S. L., and Tonello, M. S.: Holocene changes in trophic states of shallow lakes from the Pampa plain of Argentina, The Holocene, 22, 1263-1270, 2012.

Stutz, S., Tonello, M. S., Gonzalez Sagraria, M. A., Navarro, D., and Fontana, S.: Historia ambiental de los lagos someros de la llanura Pampeana desde el Holoceno medio. Inferencias paleoclimáticas, Lat. Am. J. Sedimentol. Basin Anal., 21, 119-138, 2015.

Takahashi, K.: The atmospheric circulation associated with extreme rainfall events in Piura, Peru, during the 1997-1998 and 2002 El Niño events, Ann. Geophys., 22, 3917-3926, 2004.

Thomas, D. J.: Order without government: the society of the Pemons indians of Venezuela, University of Illinois Press, Illinois, 1982.

Thompson, D. W. J. and Wallace, J. M.: Annular modes in the extratropical circulation - Part I: Month-to-Month Variability*, J. Clim., 13, 1000-1016, 2000.

Tonello, M. S. and Prieto, A. R.: Modern vegetation-pollen-climate relationships for the Pampa grasslands of Argentina, J. Biogeogr., 35, 926-938, 2008.

Tonello, M. S., Mancini, M. V., and Seppä, H.: Quantitative reconstruction of Holocene precipitation changes in southern Patagonia, Quat. Res., 72, 410-420, 2009.

Tonello, M. S., Mancini, M. V., de Porras, M. E., Bamonte, F. P., and Sottile, G.: Pollen and climate dataset at southern Patagonia: evaluating weaknesses and strengths for quantitative palaeoclimatic reconstructions, Valdivia, Chile, 2010.

Urrego, D. H., Bush, M. B., and Silman, M. R.: A long history of cloud and forest migration from Lake Consuelo, Peru, Quat. Res., 73, 364-373, 2010.

Urrego Giraldo, L. E. and Berrio M., J. C.: Los estudios paleoecológicos en el Chocó Biogeográfico durante el Holoceno medio y reciente., in Diversidad Biótica IV. El Chocó Biogeográfico/Costa Pacífica, edited by J.O. Rangel-Ch, Universidad Nacional de Colombia, Instituto de Ciencias Naturales, Conservación Internacional, Bogotá, DC, Colombia., 2011.

Urrego Giraldo, L. E. and del Valle A., J. I.: Reconstrucción de la sucesión de un bosque de "Guandal"(Pacífico Colombiano) durante el Holoceno reciente, Caldasia, 24, 425-443, 2002.

Valencia, B. G., Urrego, D. H., Silman, M. R., and Bush, M. B.: From ice age to modern: a record of landscape change in an Andean cloud forest: Cloud forest history: from ice age to modern, J. Biogeogr., 37, 1637-1647, 2010.

Van Boxel, J. H., González-Carranza, Z., Hooghiemstra, H., Bierkens, M., and Vélez, M. I.: Reconstructing past precipitation from lake levels and inverse modelling for Andean Lake La Cocha, J. Palaeolim., 51, 63-77, 2013.

Van der Hammen, T. and Correal Urrego, G.: Prehistoric man of the Sabana de Bogotá: Data for an ecological prehistory, Palaeogeogr. Palaeoclimatol. Palaeoecol., 25, 179-190, 1978.

Van Geel, B. and Van der Hammen, T.: Upper Quaternary vegetational and climatic secuense of the Fúquene area (Eastern Cordillera, Colombia), Palaeogeogr. Palaeoclimatol. Palaeoecol., 14, 9-92, 1973. 
Vélez, M. I., Wille, M., Hooghiemstra, H., Metcalfe, S., Vandenberghe, J., and Van der Borg, K.: Late Holocene environmental history of southern Chocó region, Pacific Colombia; sediment, diatom and pollen analysis of core El Caimito, Palaeogeogr. Palaeoclimatol. Palaeoecol., 173, 197-214, 2001.

Vera, C., Higgins, W., Amador, J., Ambrizzi, T., Garreaud, R., Gochis, D., Gutzler, D., Lettenmaier, D., Marengo, J., Mechoso, C. R., Nogues-Paegle, J., Dias, P. L. S., and Zhang, C.: Toward a Unified View of the American Monsoon Systems, J. Climate, 19, 4977-5000, 2006.

Viglizzo, E. F. and Frank, F. C.: Ecological interactions, feedbacks, thresholds and collapses in the Argentine Pampas in response to climate and farming during the last century, Quat. Int., 158, 122 126, 2006.

Villalba, R., Grosjean, M., and Kiefer, T.: Long-term multiproxy climate reconstructions and dynamics in South America (LOTRED-SA): State of the art and perspectives, Palaeogeogr. Palaeoclimatol. Palaeoecol., 281, 175-179, 2009.

Villa-Martínez, R., Villagrán, C., and Jenny, B.: Pollen evidence for late-Holocene climatic variability at Laguna de Aculeo, Central Chile (lat. 34 S), The Holocene, 14, 361-367, 2004.

Vuille, M. and Garreaud, R. D.: Ocean-atmosphere interactions on interannual to decadal timescales, in Handbook of Environmental Change, vol. 1, edited by: J. A. Matthews, P. J. Bartlein, K. R. Briffa, A. Dawson, A. de Vernal, T. Denham, S. C. Fritz, and F. Oldfield, Sage Publications, London, Los Angeles, New Delhi, Singapore, 471-496, 2012.

Vuille, M. and Werner, M.: Stable isotopes in precipitation recording South American summer monsoon and ENSO variability - observations and model results, Clim. Dynam., 25, 401-413, 2005.

Vuille, M., Bradley, R. S., and Keimig, F.: Interannual climate variability in the Central Andes and its relation to tropical Pacific and Atlantic forcing, J. Geophys. Res. Atmospheres, 105, 1244712460, 2000.

Vuille, M., Burns, S. J., Taylor, B. L., Cruz, F. W., Bird, B. W., Abbott, M. B., Kanner, L. C., Cheng, H., and Novello, V. F.: A review of the South American monsoon history as recorded in stable isotopic proxies over the past two millennia, Clim. Past, 8, 1309-1321, 2012.

Wang, H. and Fu, R.: Cross-equatorial flow and seasonal cycle of precipitation over South America, J. Clim., 15, 1591-1608, 2002.

Weng, C., Bush, M. B., and Athens, J. S.: Holocene climate change and hydrarch succession in lowland Amazonian Ecuador, Rev. Palaeobot. Palynol., 120, 73-90, 2002.

Whitlock, C., Bianchi, M. M., Bartlein, P. J., Markgraf, V., Marlon, J., Walsh, M., and McCoy, N.: Postglacial vegetation, climate, and fire history along the east side of the Andes (lat $41-42.5^{\circ} \mathrm{S}$ ), Argentina, Quat. Res., 66, 187-201, 2006.
Whitney, B. S., Mayle, F. E., Punyasena, S., Fitzpatrick, K., Burn, M., Guillen, R., Chavez, E., Mann, D., Pennington, R. T., and Metcalfe, S.: A $45 \mathrm{kyr}$ palaeoclimate record from the lowland interior of tropical South America, Palaeogeogr. Palaeoclimatol. Palaeoecol., 307, 177-192, 2011.

Whitney, B. S., Dickau, R., Mayle, F. E., Soto, J. D., and Iriarte, J.: Pre-Columbian landscape impact and agriculture in the Monumental Mound region of the Llanos de Moxos, lowland Bolivia, Quat. Res., 80, 207-217, 2013.

Whitney, B. S., Dickau, R., Mayle, F. E., Walker, J. H., Soto, J. D., and Iriarte, J.: Pre-Columbian raised-field agriculture and landuse in the Bolivian Amazon, The Holocene, 24, 231-241, 2014.

Winsborough, B. M., Shimada, I., Newsom, L. A., Jones, J. G., and Segura, R. A.: Paleoenvironmental catastrophies on the Peruvian coast revealed in lagoon sediment cores from Pachacamac, J. Archaeol. Sci., 39, 602-614, 2012.

Wille, M., Negret, J. A., and Hooghiemstra, H.: Paleoenvironmental history of the Popayán area since 27000 yr BP at Timbio, southern Colombia, Rev. Palaeobot. Palynol., 109, 45-63, 2000.

Wille, M., Hooghiemstra, H., Behling, H., van der Borg, K., and Negret, A. J.: Environmental change in the Colombian subandean forest belt from 8 pollen records: the last $50 \mathrm{kyr}$, Vegetat. Hist. Archaeobot., 10, 61-77, 2001.

Wille, M., Hooghiemstra, H., Van Geel, B., Behling, H., de Jong, A., and Van der Borg, K.: Submillennium-scale migrations of the rainforest-savanna boundary in Colombia: ${ }^{14} \mathrm{C}$ wiggle-matching and pollen analysis of core Las Margaritas, Palaeogeogr. Palaeoclimatol. Palaeoecol., 193, 201-223, 2003.

Wille, M., Maidana, N. I., Schäbitz, F., Fey, M., Haberzettl, T., Janssen, S., Lücke, A., Mayr, C., Ohlendorf, C., Schleser, G. H., and Zolitschka, B.: Vegetation and climate dynamics in southern South America: the microfossil record of Laguna Potrok Aike, Santa Cruz, Argentina, Rev. Palaeobot. Palynol., 146, 234-246, 2007.

Williams, J. J., Gosling, W. D., Coe, A. L., Brooks, S. J., and Gulliver, P.: Four thousand years of environmental change and human activity in the Cochabamba Basin, Bolivia, Quaternary Res., 76, 58-68, 2011.

Williams, J. J., Brooks, S. J., and Gosling, W. D.: Response of chironomids to late Pleistocene and Holocene environmental change in the eastern Bolivian Andes, J. Paleolimnol., 48, 485-501, 2012.

Zárate, M. A. and Tripaldi, A.: The aeolian system of central Argentina, Aeolian Res., 3, 401-417, 2012.

Zhou, J. and Lau, K.-M.: Principal modes of interannual and decadal variability of summer rainfall over South America, Int. J. Climatol., 21, 1623-1644, 2001. 